\title{
Vestibular System Part 2: Psychophysics, Applied Aspects and General Interpretations
}

\author{
By
}

A.J. Benson - N. Bischof - W.E. Collins - A.R. Fregly - A. Graybiel F.E. Guedry $\cdot$ W.H. Johnson - L.B.W. Jongkees $\cdot$ H.H. Kornhuber $\cdot$ R. Mayne D.L. Meyer · E. Peitersen - W. Precht - K.P. Schaefer

Edited by

H.H. Kornhuber

With 198 Figure

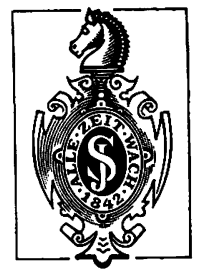

Springer-Verlag Berlin · Heidelberg • New York 1974 

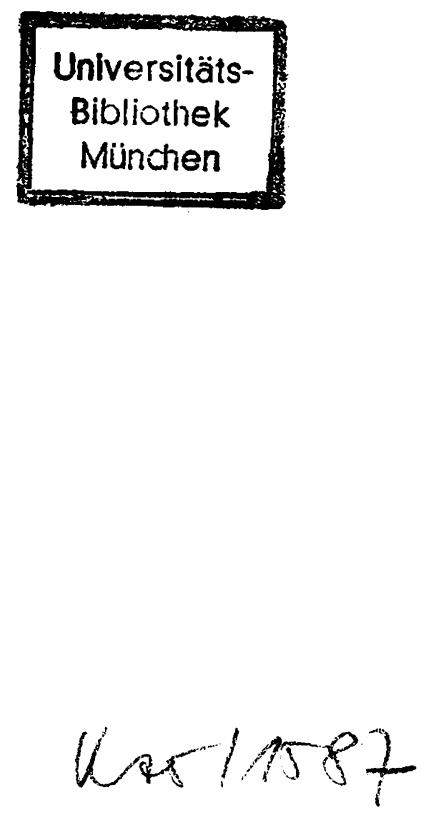

ISBN 3-540-06864-3 Springer-Verlag Berlin $\cdot$ Heidelberg $\cdot$ New York ISBN 0-387-06864-3 Springer-Verlag New York $\cdot$ Heidelberg $\cdot$ Berlin

This work is subject to copyright. All rights are reserved, whether the whole or part of the material is concernted, specifically those of translation, reprinting, re-use of illustrations, broadcasting, reproduction by photocopying machine or similar means, and storage in data banks.

Under $\S 54$ of the German Copyright Law where copies are made for other than private use, a fee is payable to the publisher, the amount of the fee to be determined by agreement with the publisher. (C) by Springer-Verling. Berlin - Heidelberg 1974. Printed in Germany.

Library of Congress Cataloging in Publication Data. Kornhuber, Hans. Vestibular System. (Handbook of Sensory Physiology, v. 6/1-2). Contents: pt. 1. Basic Mechanisms - pt. 2. Psychophysics, Applied Aspects and General Interpretations. 1. Vestibular Apparatus. I. Bagger-Sjöbäck. II. Title. III. Series. [DN LM: 1. Vestibular A pırratus. 2. Vestibular Nuclei. WL700 H236 v. 6] QP351.H34 vol. 6/1-2 [QP471] 591.1‘82‘08s [591.1‘82]. 74-148活.

The use of registered names, trademarks, etc. in this publication does not imply, even in the absence of a specific statement, that such names are exempt from the relevant protective laws and regulations and therefore free for general use.

Typesetting and printing: Roth sel. Ww., München; Binding: Brühlsche Univerșitạttsdruckerei, Gießen 


\section{Preface}

The function of the vestibular system is not as obvious as those of vision, hearing, touch or smell. Vestibular dysfunction, however, is clearly apparent where lesions are present. It is probably for this reason that the vestibular sense was not discovered until the nineteenth century and that clinicians have continued to play a major role in basic vestibular research right up to the present. The relationship between basic and clinical research is certainly stronger in the vestibular field than in that of tactile sensation, for instance, as testified by the work of clinicians as Menière, Breuer, Bárány, Derleijn and Frenzel. In this respect the situation is similar in vestibular physiology and in endocrinology, and for the same reason.

This second part of the vestibular volume of the Handbook of Sensory Physiology will be of interest to neurologists, otologists, neurosurgeons, ophthalmologists and physiotherapists on the one hand, and psychologists, physiologists, engineers and aviation specialists on the other. For a full understanding of Part 2, it is necessary to have assimilated the basic anatomy, physiology, and biochemistry of Part 1.

Each sensory system has some motor aspects. Nociceptors, for instance, have a special relation to the spinal flexion reflex and to flexion spasticity after spinal cord lesions. Tactile afferents are strongly engaged in the regulation of voluntary finger, hand, lip, and tongue movements. However, there is no other sensory system where the motor aspects are as important as in the vestibular. The cerebellum has evolved out of the vestibular system; the cerebellar nuclei are analogous (in function and in their connections to the cerebellar cortex) to the vestibular nuclei. The study of the role of vestibular mechanisms in body posture and eye movements has made a substantial contribution to the theory of the motor system. The simpler organization of active eye movements as compared to limb movements has facilitated understanding. This book takes these facts into account.

It is hoped that this volume may represent a small step toward an understanding of this part of Nature's secrets and at the same time facilitate clinical knowledge about the vestibular system. 


\section{List of Contributors}

Benson, A.J., Neurobiology Section, R.A.F. Institute of Aviation Medicne, Farnborough, Hampshire, England

Bischof, N., California Institute of Technology, Division of Biology, Pasadena, Calif. 91109 , USA

Colsins, W.E., Psychology Laboratory, Civil Aeromedical Institute, P. O. Kox 25082, Oklahoma City, Oklahoma 73125, USA

Fregly, A. R., Naval Education and Training Support, Code N 213, Building 45, Naval Air Station, Pensacola, Florida 32508, USA

Graybiel, A., Naval Aerospace Medical Center, Pensacola, Florida 32512, USE.

Guedry, F.E., Naval Aerospace Medical Center, Pensacola, Florida 32512, USA

Johnson, W.H., Dept. of Otolaryngology and Physiology, University of Toronto, Toronto, Canada

Jongkees, L.B.W., Academisch Ziekenhuis bij de Universiteit van Amsterdam, Keel-, neus-en oorheelkundige kliniek, Amsterdam-Oud west, Eerste Helmerstraat 104, Holland

Kornhuber, H.H., Abt. f. Neurologie der Universität, D-7900 Ulm, Steinhörelstraße 9, Germany

Mayne, R., Arizona State University, Faculty of Electrical Engineering, Tempe, Arizona 85281, USA

Meyer, D.L., Universitäts-Nervenklinik D-3400 Göttingen, v. Siebold-Str. 5, Germany

Peitersen, E., University E.N.T. Clinic, Rigshospitalet, Blegdamsvej, DK-2100 Copenhagen $\varnothing$, Denmark

Precht, W., Max-Planck-Institut für Hirnforschung, Neurobiologische Abt. D-6000 Frankfurt-Niederrad, Deutschordenstraße 40, Germany

SchaEFer, K.P., Universitäts-Nervenklinik, D-3400 Göttingen, v. Siebold-Str. 5, Germany 


\title{
Vestibular System \\ Part 2: Psychophysics, Applied Aspects and General Interpretations
}

\section{Contents}

\author{
E. Psychophysics
}

Chapter I

Chapter II

Chapter I

Chapter II

Chapter III

Chapter IV

Chapter V

Chapter VI

Chapter VII

Chapter VIII

Chapter IX

Chapter X

Chapter XI

Chapter I

Chapter II

Author Index Subject Index
Psychophysics of Vestibular Sensation. By F. E. Guedry. With 39 Figures . . . . . . . . . . . . . . . . . Optic-Vestibular Orientation to the Vertical. By N. BIschof. With 12 Figures . . . . . . . . . . . . . . 155

\section{F. Applied Aspects}

Nystagmus and Related Phenomena in Man: An Outline of Otoneurology. By H.H. KornhuBER. With 16 Figures 193 Measurement of Otolith Function in Man. By A. GraYBIEL. With 19 Figures. . . . . . . . . . . . 233 Measurement of Vestibulo-Spinal Responses in Man. By E. Pettersen. With 3 Figures . . . . . . . . . . . 267 Modification of the Response to Angular Accelerations by Linear Accelerations. By A.J. Benson. With 14 Figures 281 Vestibular Ataxia and its Measurement in Man. By A.R. Frealy. With 11 Figures . . . . . . . . . . . . 321 Arousal and Vestibular Habituation. By W.E. Collins. With 2 Figures . . . . . . . . . . . . . . . . . . 361 Habituation of Vestibular Responses with and without Visual Stimulation. By W.E. Collins. With 8 Figures 369 Motion Sickness. Part 1. Aetiology and Autonomic Effects. By W.H. Johnson. With 5 Figures . . . . . . 389 Part 2. Some Sensory Aspects. By L. B.W. JongkeEs. With 4 Figures . . . . . . . . . . . . . . . . . . 405 Pathology of Vestibular Sensation. By L.B.W. JongkEES. With 16 Figures . . . . . . . . . . . . . . 413 Characteristics of Vestibular Neurons after Acute and Chronic Labyrinthine Destruction. By W. Precht. With 4 Figures . . . . . . . . . . . . . . . . . . . . 451 Compensation of Vestibular Lesions. By K.P. SchaEfer and D.L. MEYer. With 4 Figures 463

\section{G. General Interpretations}

A Systems Concept of the Vestibular Organs. By $\mathrm{R}$. MAYNE. With 21 Figures . . . . . . . . . . . . . 493 The Vestibular System and the General Motor System. By H.H. Kornhuber. With 20 Figures . . . . . . . 581 645 


\section{Part 1 : Basic Mechanisms}

\section{Contents}

\section{A. Introduction}

By H.H. Kornhuber. With 5 Figures

\section{B. Comparative Morphology and Physiology}

Chapter I

Chapter II

Chapter I

Chapter II

Chapter III

Chapter IV

Chapter V

Chapter I

Chapter II

Chapter III

Chapter IV

Chapter V

Chapter VI

Chapter VII

Author Index

Subject Index
The Perception of Gravity and of Angular Acceleration I in Invertebrates. By H. MARKL. With 27 Figures Comparative Morphology and Physiology. By O.E. Lo- . weNsTEIN. With 20 Figures

\section{Peripheral Mechanisms}

Morphology of the Vestibular Sense Organs. By J. WER- SÄLL and D. BAGGER-SJöBÄCK. With 60 Figures

The Functional Significance of Semicircular Canal Size. . By G. Melvill Jones. With 4 Figures

Histochemistry and Metabolism of the Inner Ear. Byy G.F. DoHLMaN

Morphological Aspects of the Efferent Vestibular System. By R.R. GACEk. With 5 Figures

Physiological Aspects of the Efferent Vestibular System. By W. Precht. With 5 Figures

\section{Central Mechanisms}

Anatomy of the Vestibular Nuclei and their Connections. : . By A. Brodal. With 45 Figures

The Physiology of the Vestibular Nuclei. By W.Precht. : With 15 Figures

Cerebello-Vestibular Interrelations. By O. Pompeiano. . With 15 Figures

The Vestibulo-Ocular Reflex Arc. By B. Cohen. With h 20 Figures

Vestibulo-Spinal Mechanisms. By B.E. Gernandt. c. With 10 Figures

Cortical Projections of the Vestibular Nerve. By J.M. [. Fredrickson, H.H. KornhUber and D.W.F.

ScHWaRz. With 10 Figures

Vestibular Influences during Sleep. By O. Pompeiano. ). With 10 Figures 
E. Psychophysics 


\title{
Chapter II. \\ Optic-Vestibular Orientation to the Vertical
}

\author{
By \\ N. Bischof, Pasadena, Calif. (USA) \\ With 12 Figures
}

\section{Contents}

I. Introduction: On Orientation . . . . . . . . . . . . . . . . . . 155

II. Directional Constancy and the Compensation Principle . . . . . . . . . . . . 157

A. On Vertical Constancy . . . . . . . . . . . . . . . . . . . . . . . . 157

B. The Compensation Principle . . . . . . . . . . . . . . . . . . . . . . 157

C. External and Internal Compensation . . . . . . . . . . . . . . . . . . . 159

D. Allowance for Compensatory Errors . . . . . . . . . . . . . . . . . . . 160

E. Postural Direction Cues . . . . . . . . . . . . . . . . . . . . . . . . 163

F. The Significance of Vestibular Direction Cues . . . . . . . . . . . . . . . 164

III. Visual Direction Cues and the Reconstruction Principle . . . . . . . . . . . . 166

A. The Concept of Perceptual Reconstruction . . . . . . . . . . . . . . . . 166

B. Visual Direction Cues . . . . . . . . . . . . . . . . . . . . . . . . . 166

C. Visual Auto-Compensation . . . . . . . . . . . . . . . . . . . . . . . 169

D. Feed-Forward and Feed-Back Compensation . . . . . . . . . . . . . . . 173

IV. Optic-Vestibular Interaction and the Correction Principle . . . . . . . . . . 177

A. The Utilization of "Convergent Detection" . . . . . . . . . . . . . . . . 177

B. Optic-Vestibular Equivalence . . . . . . . . . . . . . . . . . . . . . . 177

C. Incongruity of Equivalent Signals . . . . . . . . . . . . . . . . . . . . 178

1. "Compromise" Solution . . . . . . . . . . . . . . . . . . . . . . . 178

2. "Alternative" Solution . . . . . . . . . . . . . . . . . . . . . . . . 178

3. "Simultaneity" Solution . . . . . . . . . . . . . . . . . . . . . . . 179

D. Error Detection and Error Correction . . . . . . . . . . . . . . . . . . 179

1. Error Detection . . . . . . . . . . . . . . . . . . . 179

2. Error Correction . . . . . . . . . . . . . . . . . . . . 180

E. Determinants of the Optic-Vestibular Weight Ratio . . . . . . . . . . . 180

References . . . . . . . . . . . . . . . . . . . . 185

\section{Introduction: On Orientation}

By "orientation" we mean the proper arrangement of an object within a frame of reference.

Using the term "proper" takes account of a connotation of value attached to the concept of orientation in common language. It may be understood either in a merely formal sense, referring to aspects of symmetry, equilibrium, and the like, or functionally: we may call an animal "well" or "poorly" oriented if it is able or unable to find its way home after having been displaced; or, generally speaking, if its "arrangement within a frame of reference" is such as to optimize the animal's (or its species') chances of survival. 
In humans, the "arrangement" may be understood to occur in the realm either of body activity or of perceptual organization, the "object" and the "frame of reference" beeing defined physically in the former case, and psychophysically in the latter. We therefore distinguish between body orientation and perceptual orientation.

We speak of spatial orientation if the frame of reference is a spatial one. Within spatial orientation two general groups can be distinguished, with the frame of reference being the essentially horizontal map of life space, on one hand, and the vertical pull of gravity, on the other. The former group, including, for instance, the problem of homing and route perception, will not be discussed here, although both the eye (as in sun-orientation, cf. BRAEMER, 1960) and the vestibular organ (BERITOFF, 1962, 1963) seem to play an important part in these performances, too. Instead, we shall restrict discussion to orientation to the vertical where, as we shall see, optic and vestibular sense are substantially involved.

Applying the dichotomy of "body" and "perceptual" orientation to this case, we may distinguish between

(1) postural equilibrium responses, i.e., motor activity serving to stabilize the intended posture of the body in the field of gravity (e.g., vestibular righting responses), and

(2) perceptual space transformations, i.e., physiological processes monitoring the constancy of space perception in the presence of factors changing the position of sense organs.

Perceptual space transformations will be called "external" if non-nervous processes like muscular mechanics are involved (as in the case of eye-movements), and "internal" if they are confined to pure nervous system activity (for further detail, see below, pp. 159 f.).

Postural equilibrium responses and perceptual space transformations are by no means independent of each other; instead, it is commonly felt that there is one and the same system producing both. In man, to be sure, much more sophistication has been invested in the study of the latter, at least in healthy subjects. The following chapter will therefore deal mostly with problems of perceptual orientation.

This report shall be organized with a functional viewpoint. In a field of research where the data available are clustered on two widely different levels of complexity - reports of perceptual phenomena on one hand, and records of neuronal discharges on the other - a functional approach seems to be most promising to bridge the gap. It might, moreover, provide us with heuristic strategies for further research both in neurophysiology and in psychophysics.

Three functional principles, i.e. three major types of information processing involved in orientational achievements, shall be distinguished below under the names of "compensation", "reconstruction", and "correction". Each of these principles has been introduced and discussed by a different group of authors: Compensation processes were first postulated by K. BüHLER (1922) and form the core of the famous, though originally not quite consistently defined "reafference principle" of von Holst and MrTtelstaEdT (1950); the importance of reconstruction processes has been stressed by Gibson (1950, 1966) and MAcKaY (1966); correction processes play an outstanding role in the perceptual theory of $\mathrm{E}$. BRUss- 
WIK $(1934,1956)$. A synopsis of these three principles has, connected with partial re-formulation, first been attempted by BIscHof (1966 b, p. 357-399). They will serve as a frame of classification of the following report.

\section{Directional Constancy and the Compensation Principle}

\section{A. On Vertical Constancy}

When exposed to a laterally tiltable, fronto-parallel luminous line in a dark room, a normal subject is able to estimate the slope of the line with quite satisfactory approximation: the inclination of the perceived contour to the apparent vertical nearly corresponds to the inclination of the physical contour with respect to the field of gravity. The sensory datum referred to by the brain in this estimation apparently consists in the slant of the line's retinal image or, more precisely, in the angle between the retinal projection of the line and a given reference axis fixed to the retina. This retinal image (the so-called proximal stimulus) serves, as it were, as the causal bridge connecting the object of interest, namely the luminous line outside in the dark room (the distal stimulus), and the perceived inclination (the phenomenon). Moreover, unless the subject contacts the distal object via an additional sensory channel (e.g., by touching), it is the only causal bridge of this kind.

Considering the latter we ought to be surprised that the relation between the retinal image and the distal object is by no means unique. Any particular inclination of the proximal stimulus contour within the retinal frame of reference may occur in the presence of a given slope of the distal stimulus line, because of the interference of a further independent variable, namely, the head tilt. When, for instance, the head is laterally inclined, the picture of a vertical line will appear on a retinal meridian different from the one upon which it is projected with upright head position. If the brain, in anthropomorphic terms, were to "rely" solely upon the information conveyed to it via the optic channel, it would be entirely unable to distinguish this situation from one in which the body remained upright but the line was tilted. The fact is, however, that the central-nervous perceptive mechanism is quite capable of making this distinction. This performance is usually referred to as "vertical constancy". The analysis of vertical constancy, then, has to start from the fundamental biological problem common to all constancy performances (others being, e.g., color, brightness, size and shape constancy): How can a veridical correspondence between the perceptual phenomenon and the distal object be established despite the fact that the only causal bridge intervening between them, i.e., the proximal stimulus, is disturbed unpredictably by the interference of a further variable?

\section{B. The Compensation Principle}

The solution of this general constancy problem was found, after preparatory work by Helmholtz, Hering, Mach, and others, by K. BüHler and L. Kardos (BÜHleR, 1922; KaRdos, 1928, 1929; BRUnswik and KaRdos, 1929) and later 
restated by von Holst and Mrttelstaedt (1950). The basic idea is this: the organism neutralizes the interference by repeating it with reversed sign. Since a process of this kind may aptly be called "compensatory", BiscHoF (1966 b) has proposed the term compensation principle to characterize this form of biological information processing.

The compensation principle is illustrated by the flow diagram Fig. 1a. The sensory channel $S$ (generally the eye) is affected by a proximal stimulus, the latter

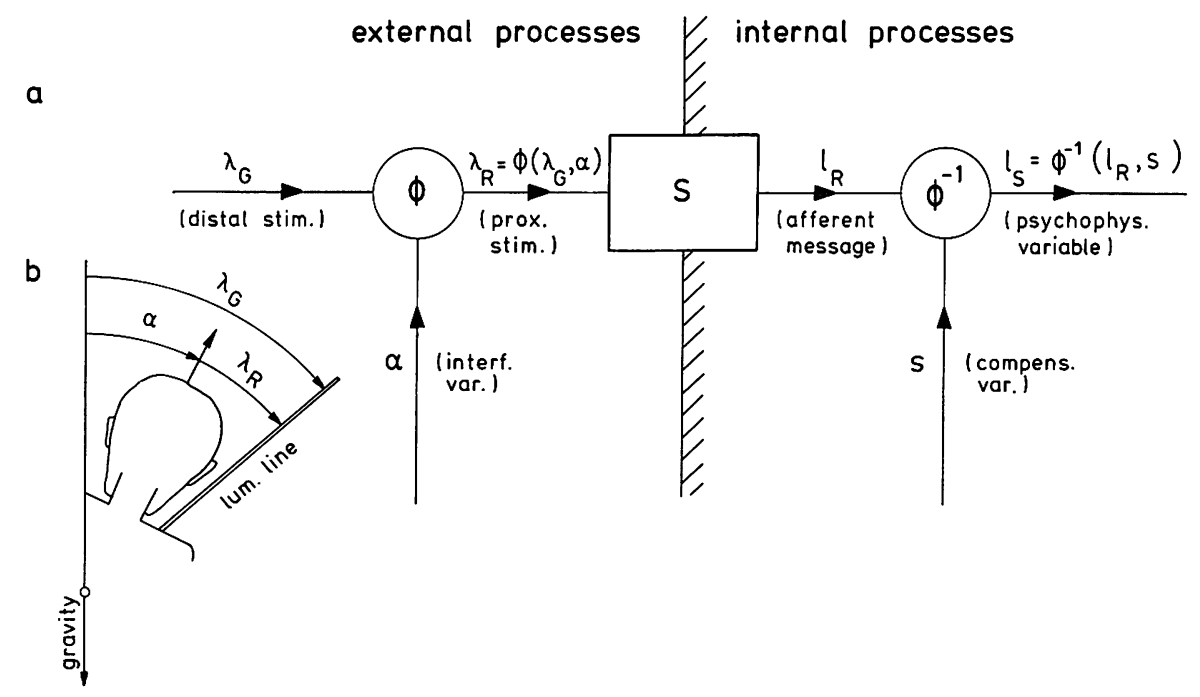

Fig. 1. a) Control diagram of the compensation principle. Here and in all subsequent block diagrams arrows represent variables, and boxes represent operators. Orientation of arrows denotes direction of causal influence. $\Phi=$ interference function, $\Phi^{-1}=$ compensatory function, $S=$ mapping function of sensory channel. b) Interference function in the perception of verticality. Distal stimulus $\left(\lambda_{G}\right)$ equals the sum of interfering variable $(a)$ and proximal stimulus $\left(\lambda_{\mathrm{R}}\right)$, if orientation of angles is uniformly defined (here: clockwise inclinations positive, when viewed from Subject)

depending upon a distal stimulus and an "interfering variable", according to an "interference function" $\Phi$. In our case, the interfering variable is the angle of head tilt $(a)$, while the inclination $\lambda$ of the luminous line relative to gravity (subscript $G$ ) is the distal stimulus. The slant of the line measured within the retinal coordinate system (subscript $\mathrm{R}$ ) can serve as a representative of the proximal stimulus. The interference function has the form of a simple subtraction, as shown in Fig. $1 \mathrm{~b}$ :

$$
\lambda_{\mathrm{R}}=\lambda_{\mathrm{G}}-a .
$$

The proximal stimulus is reported to higher central-nervous centers by means of afferent messages $\left(l_{R}\right)$. Making use of this information, now, the organism has to arrive at a psychophysical variable ${ }^{1}\left(l_{\mathrm{S}}\right)$ representing veridically the distal

1 By the expression "a psychophysical variable" we denote a hypothetical central-nervous process thought directly to underly a consciously experienced phenomenon (cf. also BIschoF, 1966a). 
stimulus. This is done by means of a compensatory process consisting of the following two operations:

(1) The organism ascertains in a suitable way a representation of the interfering variable, the "compensatory variable" $(s)$.

(2) This compensatory variable is fed into the afferent information flow in such a way as to compensate for the influence of the interfering variable ("compensatory function").

In Fig. la the compensatory function is denoted by $\Phi^{-1}$, since it can easily be seen that in the ideal case it would have to be exactly the inverse of the interference function. In our case, consequently, the ideal compensatory function would be an addition:

$$
l_{\mathrm{S}}=l_{\mathrm{R}}+s
$$

In connection with the compensation principle three main questions arise: (1) Where is the compensatory process performed? (2) How should the flow diagram be modified to take account of the compensatory errors recorded under experimental conditions and in every-day life? (3) Where does the organism obtain the information about the interfering variable needed to determine the compensatory variable? These problems will be discussed successively in the following sections, with respect to the special case of vertical constancy.

\section{External and Internal Compensation}

As far as localization is concerned, two possible types of compensation are conceivable: (1) "external" compensation outside the boundary of neurophysiological processes, and (2) "internal" compensation within the central nervous system. Only the second possibility is taken into account in Fig. 1. The first is more obvious and easier to analyse. It consists in the so-called ocular countertorsion (rolling of the eyeballs around their sagittal axes). In the ideal case the amount of countertorsion should exactly equal the degree of lateral head tilt, thus leading to complete constancy of the retinal stimulus pattern. This, however, is never attained in any vertebrate species. In man, particularly, the countertorsion response can only be called vestigial (FIScher, 1927, 1930a; Woellner and Graybiel, 1959; Schöne, 1962 ; Miller, 1962 ; Miller and Graybiel, 1963 ; Colenbrander, 1964; Kellogg, 1965; Brandt and Fluur, 1966, 1967; Udo de Haes, 1970; Bischof and Scheerer, 1970). When plotted against head tilt, ocular countertorsion shows a sinusoidal curve with extreme values ocurring at tilts of about $60^{\circ}$. Even at its extremes, the response seldom exceeds values of 6- $8^{\circ}$, being, therefore, far too small to account for the compensatory achievements actually observed.

Consequently, there remains only the alternative of assuming an "internal" compensation, i.e., a central-nervous processing of the optical afference according to Fig. 1. Formally, such a process could be conceived as a rotatory transformation of a functional coordinate system, the latter being the physiological correlate of phenomenal space. The anatomical localization of these processes is still open to speculation, although recent neurophysiological findings (cf. chapter Fredrickson, 
Kornhuber and Schwarz, this volume), contradicting the earlier opinion that no vestibular afferences reach the cerebral cortex, may turn out to be a first step towards answering this obscure question.

\section{Allowance for Compensatory Errors}

The argumentation in favor of the compensation principle (see above pp. $158 \mathrm{f}$.) may sound somewhat artificial, as it starts from the fictitious presupposition of exact veridicality of directional perception. This presupposition is, indeed, only approximately fulfilled in every-day life, and even larger deviations occur under experimental conditions.

If the optical stimulus field is reduced to a single luminous rod in a dark room, a subject's apparent vertical (as indicated by his setting of the rod) will exhibit systematic deviations from the physical plumbline, especially if the body is in a tilted position (cf. Fig. 2). Large amounts of lateral body tilt are undercompensated (AUBERT, 1861), i.e., the apparent vertical deviates towards body axis, whereas moderate amounts of tilt are sometimes overcompensated (MüLlER, 1916), i.e., the apparent vertical deviates in the opposite direction (A and E phenomenon, respectively: Udo de HaEs, 1970; Schöne and Udo de HaEs, 1971; for a review of earlier investigations, see Bischоғ, $1966 \mathrm{c}$, pp. $474 \mathrm{f}$.). Errors of the same order of magnitude occur with forward-backward body tilt (BRECHER and SCHUBERT, 1934; SCHÖNE, 1962, 1964; Correis et al., 1965). Considerable deviations are also observed when the subject is presented with an optical stimulus pattern containing one or more distinct main axes besides the luminous rod, provided that none of the main axes coincides with the pull of gravity. This phenomenon has been called "Richtungsinduktion" (directional induction) by KLEINT (1936). It obtains with such stimulus configurations as a field of parallel stripes (HoFMaN and BIELschowsky, 1909; Gibson and Radner, 1937; Bischof and Scheerer, 1970), a grid pattern (Boring, 1952; ManN, 1952), or a luminous frame (Witkin and Asch, 1948; Witkin, 1949 b; Passey, 1950; Young, 1959; Naylor, 1963, 1965; Bertini, 1964; Morant and Aronoff, 1966). Under such conditions the subject's apparent vertical, as shown by his settings of the luminous rod, is "attracted" to a certain degree by the axes of the stimulus pattern. Directional induction effects are strongest with stimulus patterns that are closely similar to natural environments except for their slanted bearing. Such situations are created when the subject observes a natural scene through a suitable mirror system (WERTHeiner, 1912; Grrson and Mowrer, 1938; AsCH and W $W_{\text {ITKIN }}$ 1948a) or through prism spectacles (Kohler, 1951; Ohwaki, 1961; Witkin and Asch, 1948b; Witkin, 1949a), or if the natural scene is tilted as a whole, e.g., in a rotatable dummy room ("haunted swing", Woon, 1895; Kleint, 1936; Asci and W $W_{\text {thin, }} 1948$ b; Mann, 1952); see also Howard and TempleTON (1966).

In the flow diagram (Fig. 1), three possible sources for deviations of this kind are conceivable: (i) the afference $l_{\mathbf{R}}$ may be a distorted image of the proximal stimulus configuration $\lambda_{\mathrm{R}}$. (ii) The compensatory variable $s$ may be an inaccurate representation of the interfering variable $\alpha$. (iii) The compensatory function $\Phi^{-1}$ may differ from a mathematically exact summation process.

In this connection the three variables $l_{\mathrm{R}}, l_{\mathrm{S}}$, and $s$ merit further consideration ${ }^{2}$. First, these quantities are to be regarded as "hypothetical constructs" in the sense of the terminological differentiation proposed by McCorquodale and MeenL (1948); i.e., they are meant to be not directly observable, but nevertheless physically existing, links of an innerorganismic causal chain. Simultaneously, however, they are "intervening variables" in the stricter sense defined by the authors - viz., they are conceived as products of a mere mental abstraction drawn out of (unknown) physiological entities likely to be in fact much more complex. The same holds for the above-mentioned compensatory operation $\Phi^{-1}$.

2 For more detailed discussion, see Bischof and Scheerer (1970). 


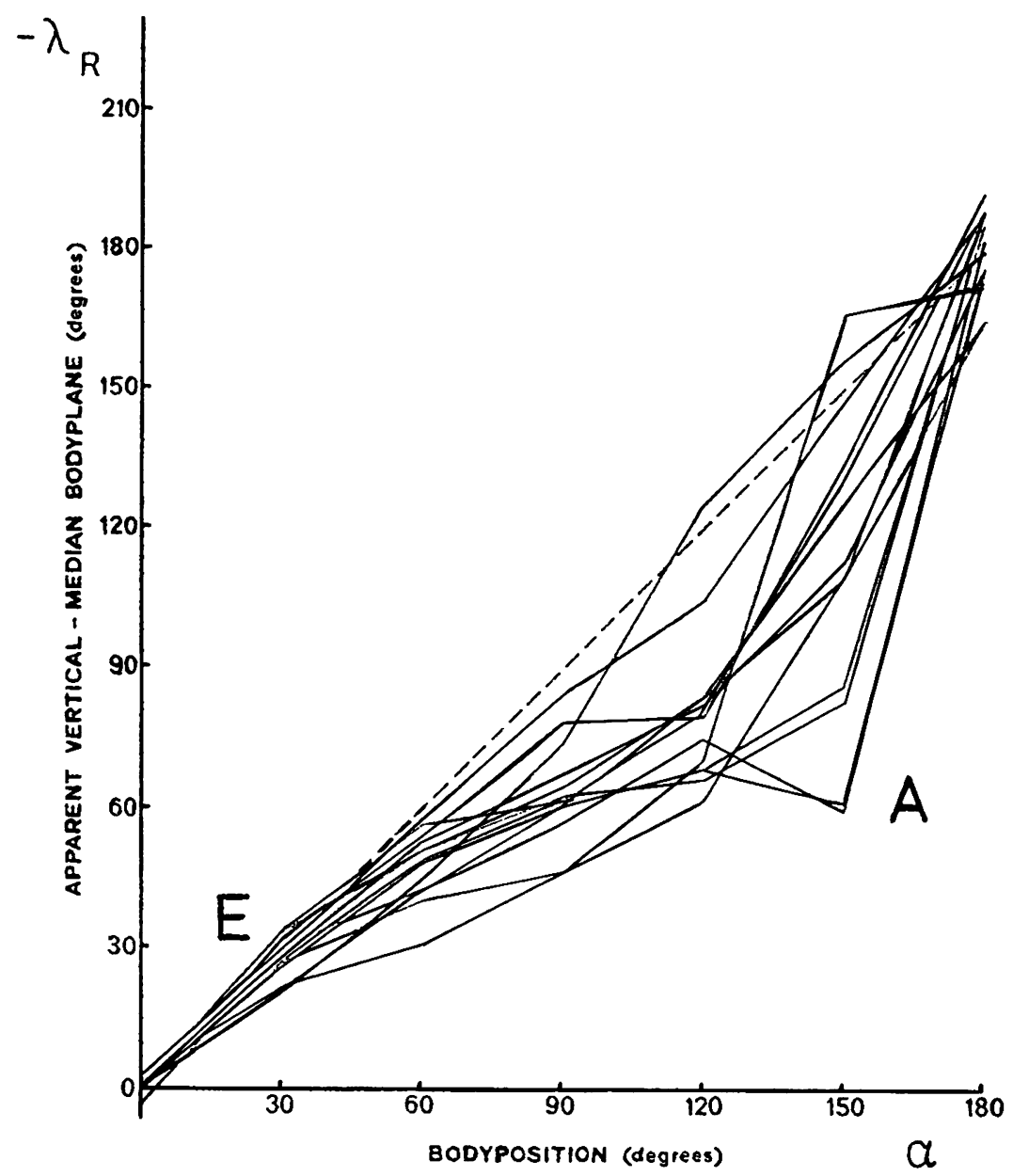

Fig. 2. Apparent vertical as a function of lateral body tilt for $13 \mathrm{Ss}$ (according to Udo DE HAES 1970). Abscissa: Clockwise body tilt. Ordinate: Inclination of a luminous rod, set to Ss apparent vertical, measured in retinal coordinates with inverted sign (for explanation, see below, p. 162). Dotted line indicates ideal veridicality of directional perception. E- (Müller) Phenomenon: measured value above dotted line (as shown in some Ss with body tilt of $30^{\circ}$ ), A- (AUBERT) phenomenon: measured value below dotted line (most marked in the majority of Ss under body tilt of $150^{\circ}$ )

With regard to the three alternatives listed above, Bischof and Scheeren (1970) arrive at the following proposition: If deviations from ideal veridicality in directional perception consist merely in rigid orthogonal rotations of phenomenal space without angular distortions occurring, they can be due solely to inaccuracy of the compensatory variable (alternative ii accepted), whereas the input-output characteristics of the optic channel and the compensatory summation process must be linear (i and iii rejected). 
In this case, an indirect measure for the compensatory variable $s$ could be derived from the setting of a luminous rod to the apparent vertical: If (i) $\lambda_{\mathrm{R}}=l_{\mathrm{R}}$, and (iii) $l_{\mathrm{S}}=l_{\mathrm{R}}+s$, and if further the apparent inclination $l_{\mathrm{S}}$ of the rod is zero (= vertical), then we should arrive at $\lambda_{\mathrm{R}}=l_{\mathrm{R}}=l_{\mathrm{S}-s}=-s$. Thus the proximal stimulus $\lambda_{\mathrm{R}}$ with reversed sign, as plotted in Fig. 2 , could serve as an operational measure for $s$.

As to the premise of this proposition, GIBSon and RADNER (1937, p. 464) state that the apparent vertical and horizontal "behave as if they were aspects of a single system for visual orientation"; the authors add, however, that both axes nevertheless "are not rigidly linked together; there is, as it were, a certain amount of 'play' or 'lost motion' between them". This angular distortion phenomenon was observed as an after-effect of prolonged exposure of an optical stimulus pattern containing (or consisting of) one predominating axis. Under these conditions, two factors seem to be involved in direction perception. They generate, respectively, (a) a so-called "normalization effect", which amounts to a rigid transformation of the phenomenal frame of reference as a whole (GIBson, 1937a, b; Gibson and RADNER, 1937), and (b) a "satiation effect", which only occurs in the vicinity of the stimulus axis, thus indeed impairing the orthogonality of space perception (KöHLER and WALLACH, 1944). The latter phenomenon can probably be accounted for in terms of adaptation or inhibition of orientation detectors in the visual channel S of Fig. 1 (Sutherland, 1961 ; Coltheart, 1971; cf. also Carpenter and Blakemore, 1974). Thus, possibility (i), as listed above, cannot be ruled out entirely. However, satiation seems to be a second order effect. By factoring out the normalization effect be means of a "split-field technique", a magnitude of maximally $1.5^{\circ}$ has been found for the satiation phenomenon (MORANT and Mistovich, 1960; Morant and HaRRIS, 1965).

These studies, to be sure, have only been performed with upright body posture. In a survey of the literature, unfortunately, no investigation dealing with the influence of body tilt on the orthogonality of space perception could be found. This leaves alternative (iii) undecided. Actually, some authors did record the apparent vertical and horizontal alternately in the same subjects as a function of head tilt, body tilt, or centrifuging, both with and without optical direction cues presented (Gibson and Mowrer, 1938; Asch and Witkin, 1948a, b; Witkin and Asch, 1948a, b; Bitrerman and Worchel, 1953, Graybiel and Clark, 1962). However, these experiments yield no answer to our problem since they are not sufficiently precise for that aim or, as in the studies of the WITKIN group, because of some peculiarities in the data analysis performed by the investigators. Nevertheless, the authors do not seem to have encountered a conspicuous decay of perceptual space orthogonality. Generally, one may presume that if body tilt and the like did produce startling angular distortions, this would have attracted the attention of some of the numerous investigators of vertical constancy during the past century, especially since under pathological conditions (cerebral lesions) or with inadequate stimulation (e.g., by electric currents) considerable distortions of the space coordinates have been repeatedly observed and reported under the name of metamorphosia or dysmorphosia by Gelb (1926), Bender and Jung (1948), Halpern (1949), Derwort (1953) and others. 


\section{E. Postural Direction Cues}

For the time being we may therefore assume that the errors of directional perception observed under physiological conditions are due virtually alone to the compensatory quantity $s$ not precisely coinciding with the head inclination $a$. Thus the third problem stated above (see p. 159), namely, where the organism obtains a representation of $\alpha$, becomes crucial. Clearly, the sources of pertinent information have to be looked for in the realm of stimulus parameters that are correlated with head and/or body tilt. Such parameters are hereafter referred to as "direction cues".

The sensory systems thought to be capable of providing direction cues are usually classified into (1) optical and (2) postural groups. The postural group may be subdivided into (a) tactile, (b) kinesthetic, and (c) vestibular cues.

(a) The distribution of pressure on the body surface may well be taken into account as a direction cue, as its maximum corresponds to the physical "down" unless, to be sure, the support at the surface of contact is in a slanted position (Gibson, 1966). The functional effectiveness of this factor at least for the "posture reflexes" has been demonstrated by MAGNUS (1924), its relevance for verticality perception follows from experiments of SchöNE and Udo DE HAES (1968, 1971).

(b) Coping with gravitation necessitates a continuous tonic innervation of the whole skeletal musculature, the pattern of which has to reflect in fine gradations the distribution of forces acting upon the body. Therefore the combined messages of tension and position receptors in muscles, tendons and joints (see BrschoF, $1966 \mathrm{c}$ ) may well be used as a source of information about the arrangement of trunk, head, and limbs with respect to gravity. The importance of these factors is underlined by the fact that asymmetric body tonus brought about, for example, by means of additional weights is accompanied by changes of the apparent vertical (KLeint, 1937; Schneider and Bartiey, 1962; KLix, 1962; WERNER et al., 1951).

(c) Whereas the two aforementioned sensory systems are primarily concerned with tasks apart from the perception of body posture in the gravito-inertial field, the vestibular apparatus appears to be constructed directly to serve this purpose.

Among the vestibular cues, both ampullar and macular messages can be shown to contribute to human perception of verticality. In the maculae, phasic and tonic responses may be distinguished, according to Lowenstern and RoBerts (1950). There are few pertinent investigations deliberately involving stimulation of all vestibular portions mentioned (e.g., von Holst and Griesebach, 1951; Udo DE HAES and Schöne, 1970). In experiments with parallel swings (JongKeES, 1952; W ALSH, 1960, 1961 ; ScHöNE et al., 1967) the semicircular canals remain essentially unexcited. Devices providing steady-state head tilt, as employed by most investigators, additionally rule out phasic receptor activity in the maculae. This restricts stimulation to the tonic (non-adaptive) receptor system in the otolith apparatus, which may be considered the basic issue in postural control of vertical constancy, at least as far as the external compensatory mechanism (eye countertorsion, see above, p. 159) is concerned (Frscher, 1930a; Miller, 1962; Schöne, 1962 ; FluUr and Mellström, 1970a, b). 


\section{F. The Significance of Vestibular Direction Cues}

The question as to whether vestibular afference has a direct access also to the internal mechanisms of perceptual space transformation is comparatively more intricate.

The significance and even preponderance of the vestibular apparatus in this respect has been maintained by investigators like JoNGKeES (1952), but denied by some earlier authors (Alexander and Barany, 1904; Beck, 1912; Stigler, 1912; Garten, 1920); partly, perhaps, since the latter expected (and failed) to encounter particular "postural sensations", reported by their subjects. These authors did not realize that a sense organ might well have the function of solely controlling perceptual coordinate systems rather than contributing new qualities to the perceptual world.

There is, of course, great difficulty in assessing the relative importance of each of the three postural systems mentioned above, since they convey information about one and the same stimulus parameter and may mutually substitute for each other. Thus, it is in no way conclusive if, in the case of deficiency of one of them, the performance in question does not substantially decrease especially if the subjects have been allowed to adapt to the loss.

When, e.g., Garten (1920) and Arndts (1924) could demonstrate that the ability of subjects to judge the vertical position of their bodies remains unimpaired with tactile information being cut off by local anaesthesia, this finding nevertheless cannot disprove the possible participation of tactile direction cues in the same performance under normal conditions or after labyrinth loss.

On the other hand the same holds true for findings according to which patients with bilateral loss of labyrinth function, when tilted laterally, are still able to set a luminous rod in a dark surround in rather good alignment with the physical vertical, or even surpass the achievement of subjects without labyrinth malfunction (cf. Fischer, 1930b; GIROTTI and Bordogna, 1963; Grrotti, 1963; Miller and Graybiel, 1966; Clark and Graybiel, 1966a; GRAYBIEL et al., 1968). These experiments show that the activity of the vestibular apparatus may be substituted by other postural factors, if necessary. But they do not tell us anything about the error one is likely to commit if, as a first approximation, one ignores the latter when working with healthy subjects, and interprets the results obtained in the absence of optical cues as attributable mainly to the vestibular apparatus.

There seems to be only one consistent method for determining whether in the postural system vestibular cues are of prior importance in the perception of verticality: one has to play the vestibular information off against other conflicting postural direction cues. Experiments with this particular aim show that there is little extra-otolith postural influence on verticality perception with body tilt up to $90^{\circ}$, whereas in body positions unlikely to occur in normal life, somesthetic factors do play a role which is, however, not very marked (Schöne, 1962; Schöne and Udo de HaEs, 1968, 1971 ; Correia et al., 1965).

Unfortunately, it is still an open question as to how the organism gathers information about the direction of gravitational force from the excitation patterns of utricle and saccule, separately.

Within the framework of his "bicomponent theory", Mitrelstaedt (1964, 1966) has called attention to the fact that the formula for rotatory transformation of a Cartesian coordinate system requires information about the sine and the cosine of the angle of rotation, and that the utricle and saccule, respectively, could well be understood to supply this information. 
Actually, there is evidence that earlier views, according to which only the utricle, but not the saccule, has a static function at all (e.g., Maxwell, 1923; Versteegh, 1927; MoNally, 1929; TaIt, 1932) are untenable at least for birds and mammals and also for some fishes (Benjamins and Huizinga, 1927; HaseGawa, 1935; Perlman, 1940; Adrian, 1942; Jongkees, 1950; Lowenstein, 1950; Szentágothai, 1952; Huizinga, 1955; Meyer zum Gottesberge and Plester, 1965; FluUr and Mellström, $1970 \mathrm{~b}$ ). Whether, however, in the perception of verticality saccular and utricular information is computed in the elegant way proposed by the bicomponent theory, remains to be investigated. (For pertinent theoretical considerations, see Schöne, 1962; CorreIA et al., 1965; Young and MeIRY, 1968; SchöNe and Udo de Haes, 1970). The main difficulty with a bicomponent transformation of perceptual-space coordinates is that it could in principle be independent of otolith weight. When, however, the amount of gravito-inertial force is actually changed by means of applying centrifugal forces (SChöne, 1962, 1964; Correia et al., 1965; Miller and Graybiel, 1966; Schöne et al., 1967; Schöne and PARKer, 1967; SchöNe and Udo de HaES, 1970) marked changes of the apparent vertical do occur, showing that the aforementioned independence does not exist ${ }^{3}$.

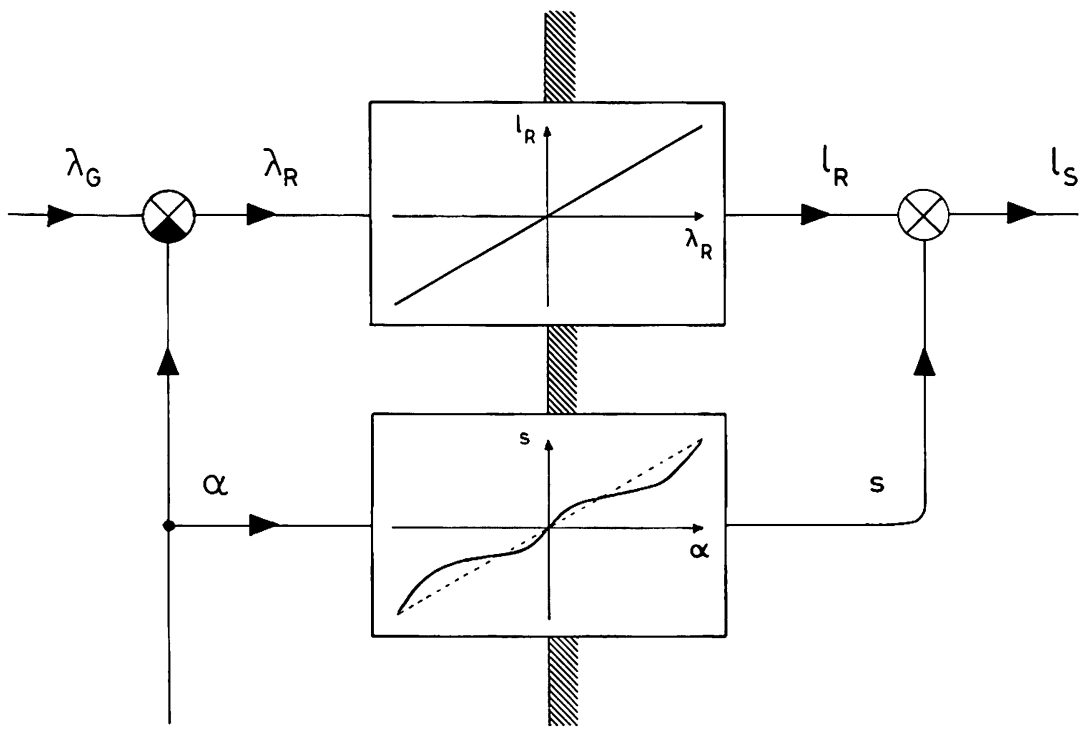

Fig. 3. Vestibular heterocompensation. Crossed circles: Operational symbols for addition. If a quadrant is black, the respective input variable is subtracted rather than added. Upper box: Visual system with linear input-output characteristics. Lower box: Otolith system with nonlinear characteristics according to Fig. 2

3 We are, of course, not referring here to changes of the apparent vertical due to changes in the direction (rather than the amount) of mechanical force during centrifugation. This effect is a physical triviality which never needed to be authenticated by psychophysicists, and which certainly did not deserve any pretentious labelling ("oculogravic illusion"). For a criticism of pertinent experiments designed by the Graybiel and Witkin groups, see Howard and Templeton (1966, pp. $197 \mathrm{ff}$.) and Bischof (1966 c, p. 481). 
While leaving this question to further analysis, we are free to characterize the function of the otolith apparatus in vertical constancy by the control diagram Fig. 3. In this diagram the $A$ and $E$ deviations result from the input-output characteristics of a single black-box labeled "otolith system", leaving aside intravestibular differentiations for the time being.

The particular type of network presented in Fig. 3, in which the compensatory variable is provided via a sensory channel separate from the one conveying information about the proximal stimulus, will be referred to hereafter as "heterocompensation" (BISCHOF, $1966 \mathrm{~b}$ ). A possible alternative, called "autocompensation" of the optic message, shall be introduced in the next section.

\section{Visual Direction Cues and the Reconstruction Principle}

\section{A. The Concept of Perceptual Reconstruction}

The idea that the eye itself should be able to mediate perceptual information about the position of the head with respect to gravity not only seems to contradict our statements above, concerning the independence of retinal and distal coordinates (see p. 157); it also does not fit into the theoretical framework of classical sensory psychology. For the latter it was a matter of trivial self-evidence that a distal object could be immediately perceived (rather than inferred by logical reasoning) only in the presence of a proximal stimulus-pattern which to a sufficient degree "looks like" the distal object or, as Gibson (1950) characterized this view, which can serve as a "facsimile" of the object. Since, now, neither the subject's own head nor the field of gravity is portrayed on the retina, perceptual information about these features cannot be conveyed via the optic system, according to classical understanding.

Modern perceptional psychology (cf. Gibson, 1950, 1966; Atrneave, 1954; Kohler, 1961; METzGer, 1968) has abandoned this unreflected conception and arrived at the following principle: Although it makes sense to conceive of the perceptual phenomena as "images" of distal objects, it is entirely misleading to expect them to portray the proximal stimulus-configurations as well; a particular. percept may be established on the basis of any sensory process whatsocver, provided only that the proximal stimulus concerned is at least correlated to the distal object. In terms of information theory, the principle maintains that the perceptual system takes advantage of the redundancy within its physical surroundings in a manner that could be compared to the way one reconstructs the text of an abbreviated or distorted telegram. Therefore, BIschof (1966 b) has proposed the term "reconstruction processes" for this kind of stimulus elaboration.

\section{B. Visual Direction Cues}

Put in anthropomorphic terms the reconstruction principle states, in essence, that the organismic perceptual system "relies" on certain regularities "expected" in its physical surroundings (LORENZ. 1959). 
Such "redundancy expectations" may be very concrete. It can be expected, for instance, that cigarette smoke rises opposite to the pull of gravity. One can show that such data, accumulated apparently in the course of individual lifeexperience, influence spatial perception without any noticeable intervention of higher cognitive processes (cf. KOHLER, 1951, 1953; KLOPP, 1956).

In addition to these, however, there are redundancy expectations of a far more generalized and abstract nature. For these is would be difficult to determine whether they have been acquired in an individual learning process or whether they are part of the phylogenetically preadapted organization of the perceptual system. This question, to be sure, is rather irrelevant in the present connection. With regard to vertical constancy two general redundancy expectations are of particular significance.
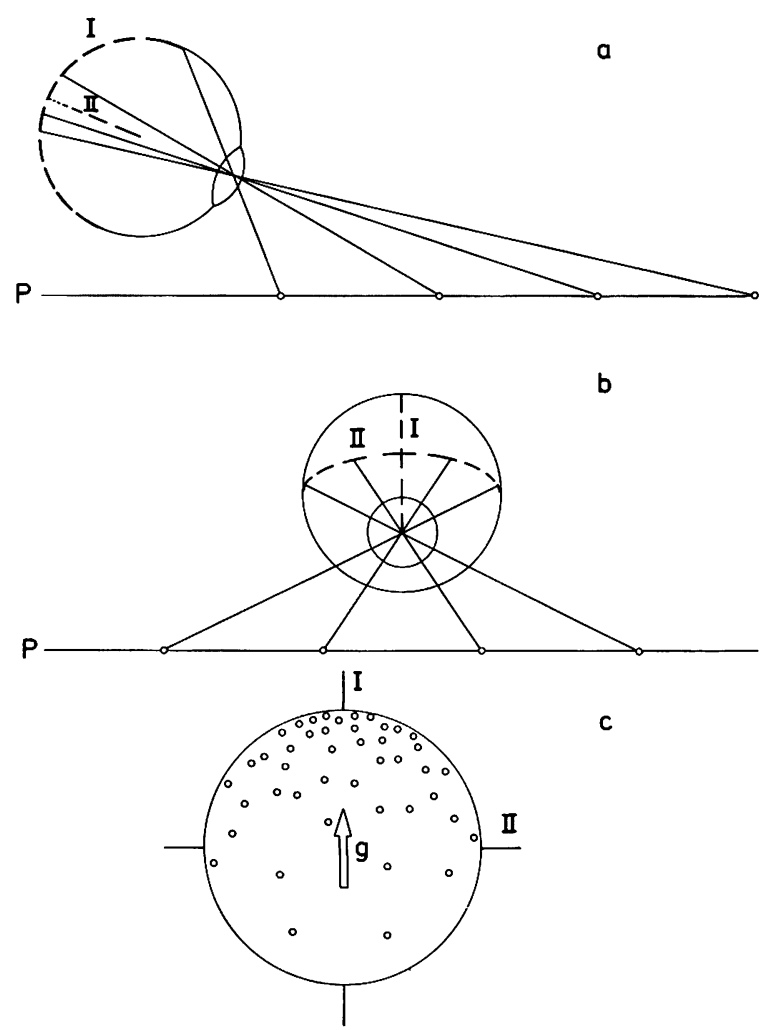

Fig. 4. Natural redundancy: Texture gradients. Equidistant marks on a plane surface (P) project on the retina in such a way that (a) the pairwise distance between proximal stimuli decreases monotonically in a retinal meridian (I) perpendicular to $\mathrm{P}$, but (b) decreases symmetrically in a meridian (II) orthogonal to the former. If the marks are not equidistant but distributed in random fashion, as they are in most of the natural surface textures, the above statements would still hold true for the local average density of proximal stimulus distribution (Fig. 4c). Thus the gradient (g) of proximal-stimulus texture (i.e., the vector defining maximal change of stimulus density) should coincide with the physical vertical, providing that the surface regarded is horizontal 
(1) The clarification of the first one has been pioneered by GiBson (1950). It consists of two mutually independent assumptions: (a) in a natural environment the texture of large surfaces is generally homogeneous, and (b) an approximately plain surface, filling large portions of the visual field, is likely to be of horizontal extension. From these two premises the following conclusion can be drawn: the mean gradient of retinal texture density, i.e., the direction in which retinal stimulation exhibits maximal average compression of its microstructure, will usually correspond to the projection of the physical vertical upon the frontal head plane (for explanation, see Fig. 4).

(2) The second redundancy expectation, the biological utilization of which has been substantiated by many authors (like, e.g., KoFFKA, 1935), assumes that under natural conditions equilibrium-states are encountered with a probability higher than that of any other comparable states. Consequently, objects of elongated shape should be likely either to stand upright (labile equilibrium), to hang down (stable equilibrium), or to lie horizontally on the ground (indifferent equilibrium), rather than to have any other preferential bearing. It can be shown by means of projective

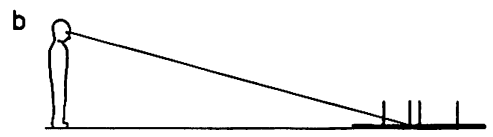

a

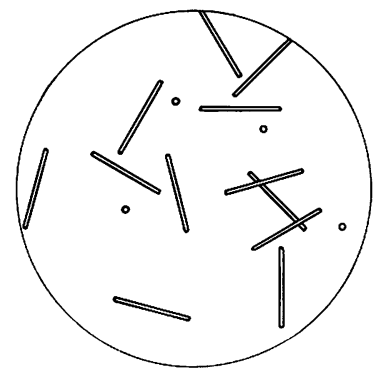

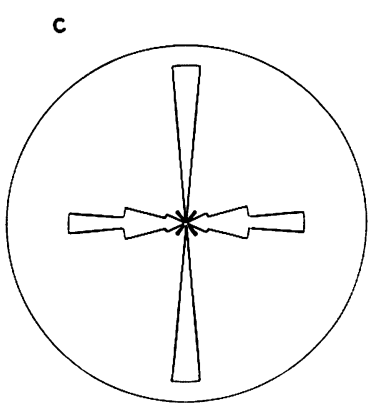

Fig. 5. Natural redundancy: Prominent figural axes. Sixteen contours of equal length, arbitrarily distributed on a horizontal surface, viewed from above (Fig. 5 a). Among the contours, 4 stand upright (indicated by little circles), and the remaining 12 lie horizontally, oriented in such a way as to provide uniform angular distribution. When this arrangement is viewed from an angle of $15 \mathrm{degr}$. (Fig. $5 \mathrm{~b}$ ), the angular distribution of the retinal stimulus contours, taken in steps of 10 degr., appears as shown in Fig. $5 \mathrm{c}$. Note that, although the number of horizontal contours exceed that of vertical contours by a factor of three, in the proximal stimulus distri-

bution the peak resulting from originally vertical contours is still dominant

geometry that the outlines of such objects, when projected on the retina, form a stimulus pattern containing two prominent figural axes perpendicular to each other, and that one of these axes again corresponds to the projection of the physical vertical upon the fronto-parallel plane (see Fig. 5).

Whenever, therefore, the stimulus pattern impinging upon the retina contains a marked figural axis (particularly if the prominence of this axis is due to many 
single contours being parallel to each other), this axis tends to be accepted as a cue for either verticality or horizontality. It should be noted that the directional cue thus provided may be ambiguous. At least it can easily be rendered so by proper experimental device. If exposed, for instance, to a striped field or a square frame, the optical system is left in absolute doubt as to (a) which of the two prominent axes is vertical, and (b) which end of the vertical axis is the upper.

Experiments carried out by Bischof and Scheerer (1970) illustrate how the organism copes with this fourfold ambiguity. The authors investigated three (female) subjects who were tilted by means of a chair rotatable around the sagittal head axis. The subjects looked towards a stimulus pattern consisting of a circular field of twenty-five parallel stripes on a dark ground. Shining on to the surface of the striped field from a pivot at its center, was a narrow light beam, which was to be set continuously to the subject's apparent vertical. The striped field was automatically rotated with a constant angular velocity of no more than 0.5 degrees per second either clockwise or counterclockwise. In each trial, the field made one full revolution of 360 degrees (taking a time of $12 \mathrm{~min}$ ), while body-tilt was held constant at one of seven values $(0,30,60,90,120,150,180$ degrees clockwise). The subject's settings of the luminous beam were automatically recorded on a time scale.

The responses of one of the subjects are plotted in Fig. 6; they show that the apparent vertical is indeed entrained by both the direction of the stripes (referred to as the "primary axis" by the authors) and the axis perpendicular to the stripes ("secondary axis"). Each end of both axes, alternately, behaves as the upper one. Incidently, it can be seen that the "attractive power" of the primary axis exceeds that of the secondary axis to a noticeable degree. Applying a FourIER-analysis to the curves shows that the primary axis is also dominant for body inclinations of $\alpha=150$ and 180 degrees, although this is not easily recognizable in the raw material, due to noise.

These results are in substantial agreement with earlier findings of GIBSON (1937a, b) and GIBSon and RADNER (1937), who observed that in the presence of a single tilted line the apparent vertical deviates towards the line if the latter's tilt is moderate, but away from it if its inclination is nearing the horizontal (cf. also Culbert, 1954 ; Morant and Beller, 1965).

\section{Visual Auto-Compensation}

When outlining in his 1966 publication what is basically the reconstruction principle, Gibson contrasts this idea with the compensation principle in the form proposed by von Holst and Mittelstaedt (1950). According to Gibson, the optical feed-back produced by displacement of the body is substantially different from an optical stimulation caused by changes in the distal environment. Thus the visual afference is not really "disturbed" by the body activity $(\alpha)$, and consequently no compensatory process is required. This consideration is felt to dispense with the concept of "a brain that copies, stores, compares, matches, and decides" (loc.cit., p. 39). This remark, however, is misleading. What really turns out to be dispensable from this point of view is what we have called "heterocompensation" (see p. 166). The need for a compensatory process as such still 


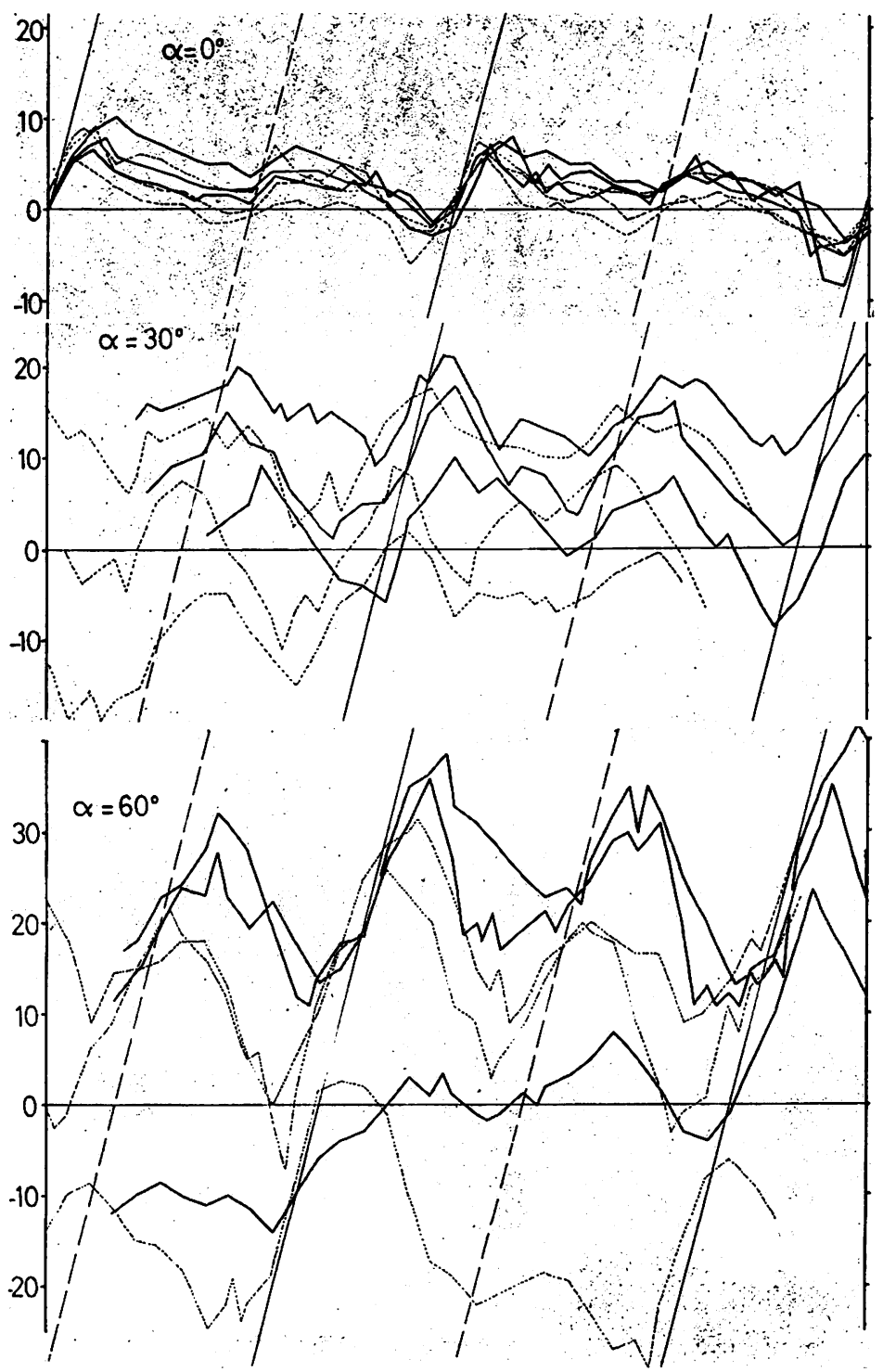

Fig. 6. Raw data of one $\mathrm{S}$ in the experiments of Brschof and Scheerer (1970). Each single diagram (a-g) comprises about 6 measurements of the apparent vertical in one particular body position (a), the latter being specified in the upper left corners. Half of the curves are from clockwise (solid lines), half from counter-clockwise rotation of the striped field (dotted lines). Ordinate: Angle $\left(\lambda_{\mathrm{G}}\right)$ between gravity and light beam set contineously to S's apparent vertical. Abscissa: Angle $\left(\beta_{\mathrm{G}}\right)$ between gravity and primary axis of background striped field. Full length of abscissa $=360$ degrees $=$ one revolution of the striped field. Since the latter rotates with constant velocity, the abscissa may also be understood as a time scale (full length $=12 \mathrm{~min}$ ). In this case, the abscissa reads from left to right for the solid curves, but from right to left for the dotted ones. Recordings in most cases begin about 1 min after the striped field starts to rotate, in order to eliminate onsat transients. Diagonals indicate the position of the striped field's primary axis (solid diagonals) or secondary axis (broken diagonals). The underlying white curves are simulations computed from the model Fig. 12 (see below, p. 184) 


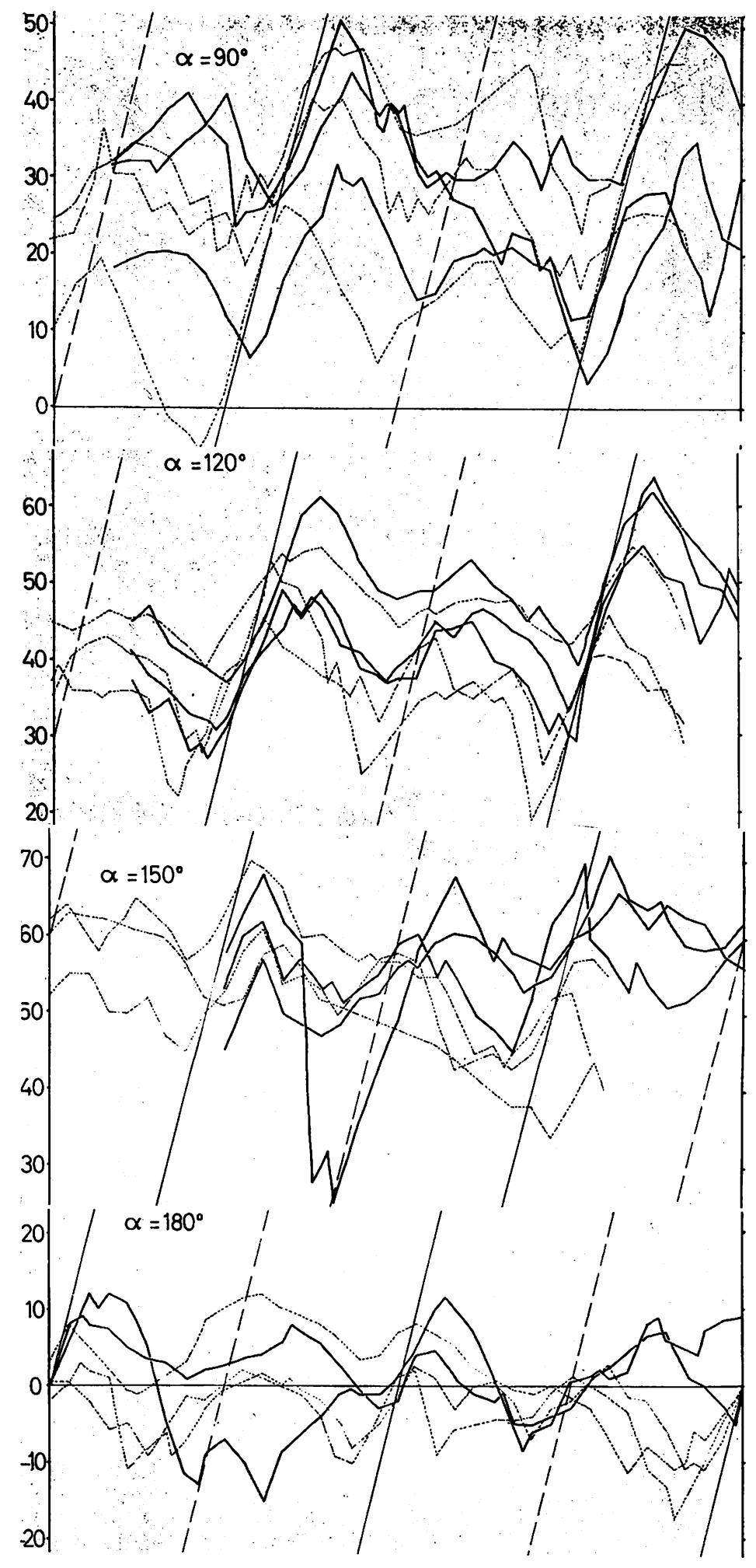


remains. It may now be, however, of a different type, namely, what could be termed "auto-compensation".

The essentials of auto-compensation are most easily understood in the case of motion constancy. Looking down at an ant-heap, e.g., causes a great deal of stimulus movement on the retina. Suppose, now, that the central nervous system would simply average the messages of all the retinal motion detectors, thus computing the vector sum of the velocities of all proximal stimulus elements. Since these elementary vectors are virtually independent of each other, the outcome of the calculation would more or less equal zero. If, however, the reafferent stimulation of smooth eye movement - caused, e.g., by pursuing one particular ant - were superimposed on the retinal stimulus-processes, then the average taken would equal with considerable exactness the eye velocity (with reversed sign, to be sure) and thus be fit to function as a compensatory variable for motion constancy. This procedure evidently is followed, erroneously, in cases of so-called "induced movement" (swimming up-stream with the bridge, etc).

Speaking generally, in auto-compensation the compensatory variable is derived directly from the afferent (in our case visual) message contaminated by the interfering variable. It presupposes the existence of a filter mechanism that selects, utilizing redundancy-expectations, the reafferent component $(\alpha)$ out of the retinal message itself (cf. Fig. 7).

How the filtering process is performed in the case of vertical constancy remains unkmown. Presumably contour detection as described by HUBeL and Wiesel (1959) is involved, with subsequent averaging to compute the predominant

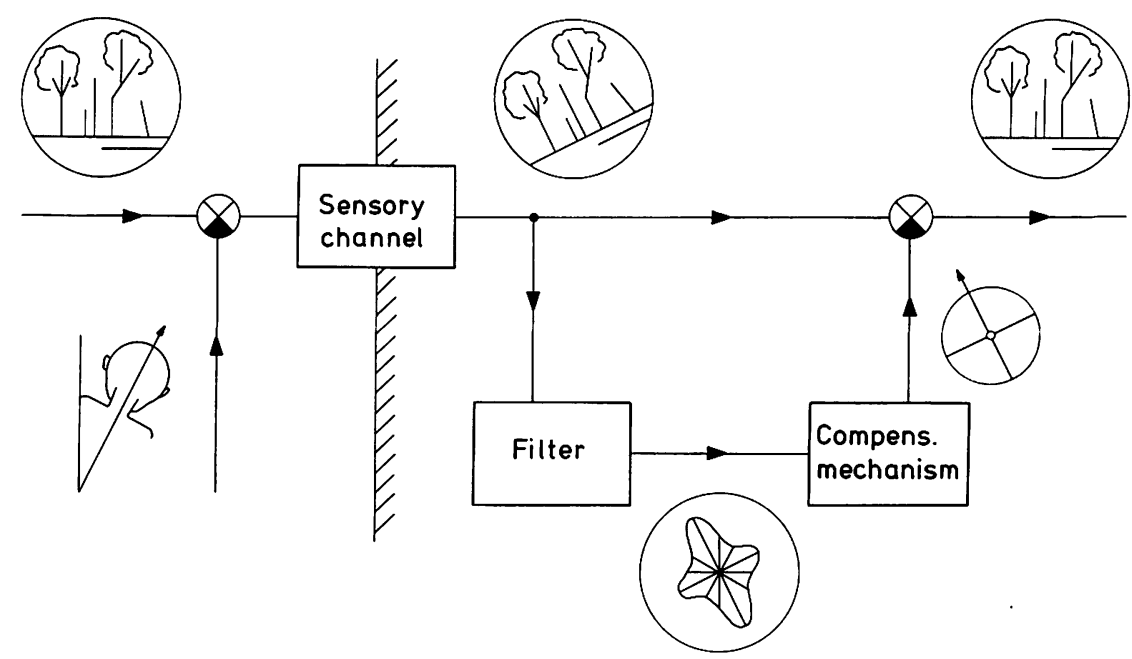

Fig. 7. Feed-forward autocompensation. A variety of distal-stimulus contours (left input variable, corresponding to $\lambda_{\mathrm{G}}$ in Fig. 1) when regarded with tilted head (lower left input variable, a) impinges on the retina in oblique orientation. When the resulting afferent message $\left(l_{R}\right)$ is "filtered" in such a way as to compute the angular distribution of contour directions (according to Fig. 5c), the resulting main axis of retinal contour elements should, with sufficiently high probability, equal head inclination (with reversed sign). Consequently, it could be used as a compensatory variable ( $s$, symbolized by a coordinate frame). When referred to these coordinates, the retinal afference should indeed be transformed in such a way as to render a sufficiently veridical perceptive representation (right output, $l_{\mathrm{S}}$ ) of distal stimuli 
proximal-stimulus axis, but for a definitive answer one must await further neurophysiological evidence. In this connection, moreover, neurophysiologists should also look for detectors sensitive to GiBSon texture-gradients (cf. p. 168).

Auto-compensation by a filter-mechanism can in some degree be compared to an adaptive process. The crucial difference between it and a genuine local adaptation is, however, that in the latter every site of the sensory field tends independently of the others to approach the zero-level of excitation; whereas in auto-compensation the zero-level of the entire stimulus field shifts uniquely, which has the important consequence that the differences appearing within the proximal stimulus pattern are preserved (cf. also MEtzger, 1968, p. $167 \mathrm{ff}$.). In the special case of verticality perception, adaptation and auto-compensation are exemplified, respectively, by the "satiation" and "normalization" effects mentioned earlier (see p. 162).

\section{Feed-Forward and Feed-Back Compensation}

In all cases of auto-compensation two fundamentally different ways of feeding the compensatory variable into the optic afference are available: the compensatory variable may enter after the branching point to the filter (feed-forward compensation, Fig. 7), or before it (feed-back compensation, Fig. 8). In terms of control theory the first model has been called a "mesh", the second one a "loop" (MitTELSTAED', 1960).

In feed-forward compensation, provided that the filter can reconstruct the head inclination without error, the compensatory variable has to equal the filter output in order to establish ideal space constancy. In feed-back compensation, on the other hand, veridicality requires that the compensatory variable

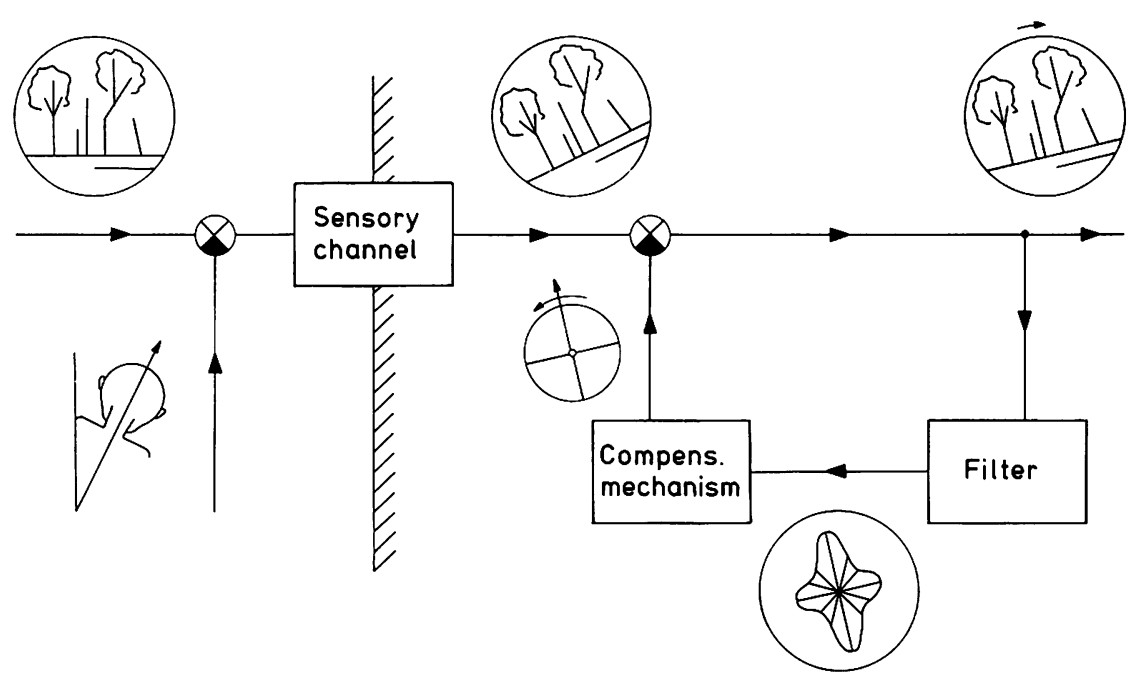

Fig. 8. Feed-back autocompensation. Differing from the system of Fig. 7 in that the perceptual output $\left(l_{\mathrm{S}}\right)$ itself undergoes the "filtering" procedure, and that the compensatory coordinate frame $(s)$ is rotated as long as the inclination of the main axis of apparent contour distribution differs from zero 
equal the time integral of the filter output. In the latter case, the magnitude of the compensatory variable will change as long as the filter output is different from zero; obviously, this process cannot come to rest with a steady value of $s$ until the filter output has vanished, i.e., until the main axis of the perceptual field has turned apparently vertical. For a broader discussion see BISCHOF and SCHEERER (1970).

Which of the two possibilities is actually realized in the organism can be readily answered in the case of "external" compensation (cf. p. 159). Here, by definition, the compensation takes place outside the boundary of neurophysiological] 'processes, whereas the compensatory variable comes from the filter that lies within this boundary. Thus, the ocular countertorsion and, incidentally, also all optokinetic reactions including nystagm, are examples for feed-back autocompensation.

Much more difficulty arises when we try to answer the same question in the field of "internal" compensation, since here the entire network is hidden within the brain, inaccessible to direct analysis. However, Bischof and ScHeERER (1970) could develop a method that allowed them to solve the problem in an indirect way. We can only outline their argumentation here; for a more thorough presentation, see the publication cited.

Regarding the oscillations in Fig.6, which are schematized in Fig. 9, it is easy to see that for each particular curve the abscissa could be partitioned into sections extending, respectively, between two successive extreme values of the oscillation of the apparent vertical. In Fig. 9a, one half of such a section is labeled as B. Each of these sections would then mark a range of stripe inclinations which have in common a particular dominance relation between the four main directions of the striped field. The abscissa of each extreme value denotes the critical inclination of the field at which one of its main directions starts or ceases to predominate over the other three in determining the apparent vertical. What, now, causes the dominance to shift from one main direction to the next? Evidently, in the course of field rotation each particular main direction is alternately perceived to be more and more, and then less and less, likely to be a valid representative of the physical vertical. This, however, presupposes a standard reference with which the perceptual system may decide about accepting a given optical main direction as a cue for verticality (cf. also DAY and WADE, 1969). Presumably, the additional information required for this decision is supplied by the postural senses. However, this information appears in crucially different forms in feed-forward and feed-back compensation, respectively.

(1) In feed-forward compensation (Fig. 7) the standard determining the dominance relations within the set of optical main directions would consist essentially ${ }^{4}$ of the vestibular compensatory variable (the "vestibular vertical") established according to Fig. 3. Thus, the inclination of a particular optical main direction with respect to the vestibular vertical decides about the acceptance of this direction as an optic cue for verticality. The vestibular vertical, however, depending as it does upon postural stimuli that are kept constant during each trial, should be expected to show limited systematic shifting at most, even when one allows for

4 Possible other postural cues (non-vestibular, non-optic) are being neglected here; this, however, is not relevant in the line of argument. 


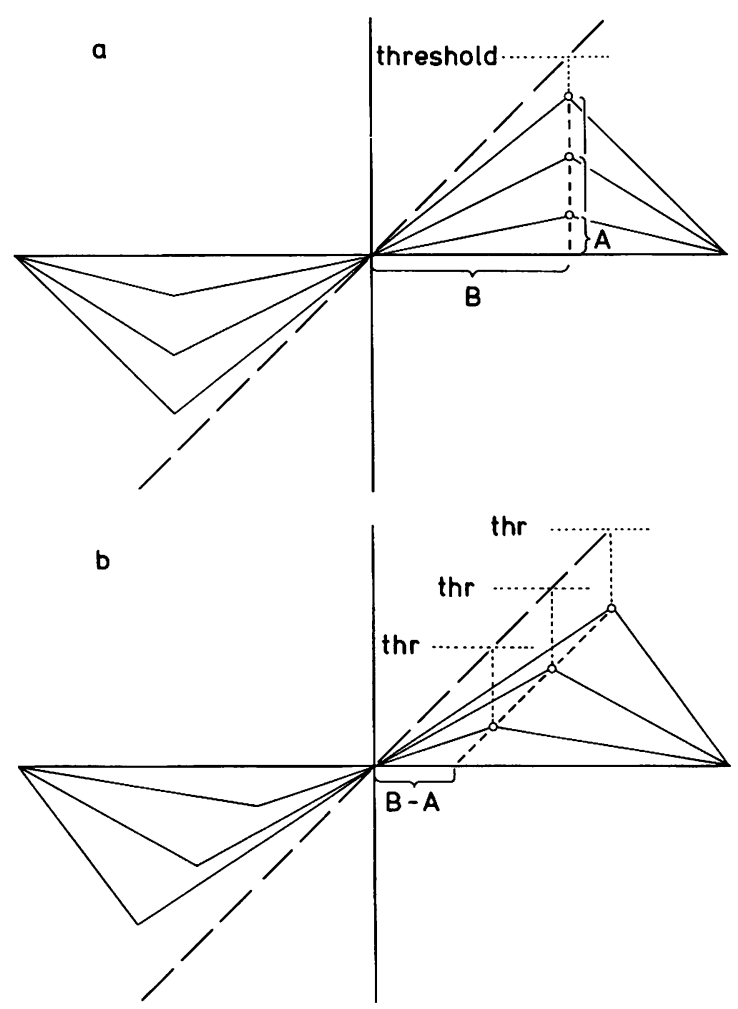

Fig. 9. Comparison of alternative compensatory mechanisms. Oscillations of an apparently vertical light beam. Ordinate: Angular inclination of light beam with respect to the DC component of oscillation (the latter representing the vestibular standard). Abscissa: Time; solid lines: settings of light beam for different body inclinations. Broken diagonals: Position of one particular main axis of the striped field. a) Feed-forward compensation. When the striped field axis has deviated far enough from the vestibular standard and reached a threshold (horizontal dotted line), the dominance will be taken over by the next axis. Hence the light beam would cease following the first axis and turn back to meet the next one. The curves should therefore show extreme values at this point. Since this process ought to be independent of body tilt, the maxima should all occur at the same time $(B)$ in the cycle, irrespective of the amount (A) of oscillation. b) Feed-back compensation. If, however, the dominance of the striped field axis depends upon its deviation from the apparent vertical, i.e., from the respective light-beam curves, the threshold (dotted lines) will vary with the amplitude of oscillation. Thus all extreme values should now have a position such that their distance to the broken diagonal is constant. This distance ought to be the difference between the abscissa value (B) and the ordinate value (A) for every extremum

moderate changes due to system dynamics (transfer characteristics and the like) of the sensory systems concerned (cf. MüLler, 1916; Miller and Graybiel, 1963; Geissler, 1965 ; McFarland and Clarkson, 1966 ; Clark and Graybiel, 1966 b; Schöne and Udo de Haes, 1968; Udo de Haes and Schöne, 1969). Hence the ranges of influence of the four main directions in the striped field are distributed according to a standard reference direction that remains virtually fixed during 
any given trial. To be sure, the reference direction will change from trial to trial, owing to there being different head inclinations, but within each of these it will remain essentially constant. This means, however, that we should find the sections of the abscissa apportioned by one and the same ratio regardless of head inclination, as indicated in Fig. 9a.

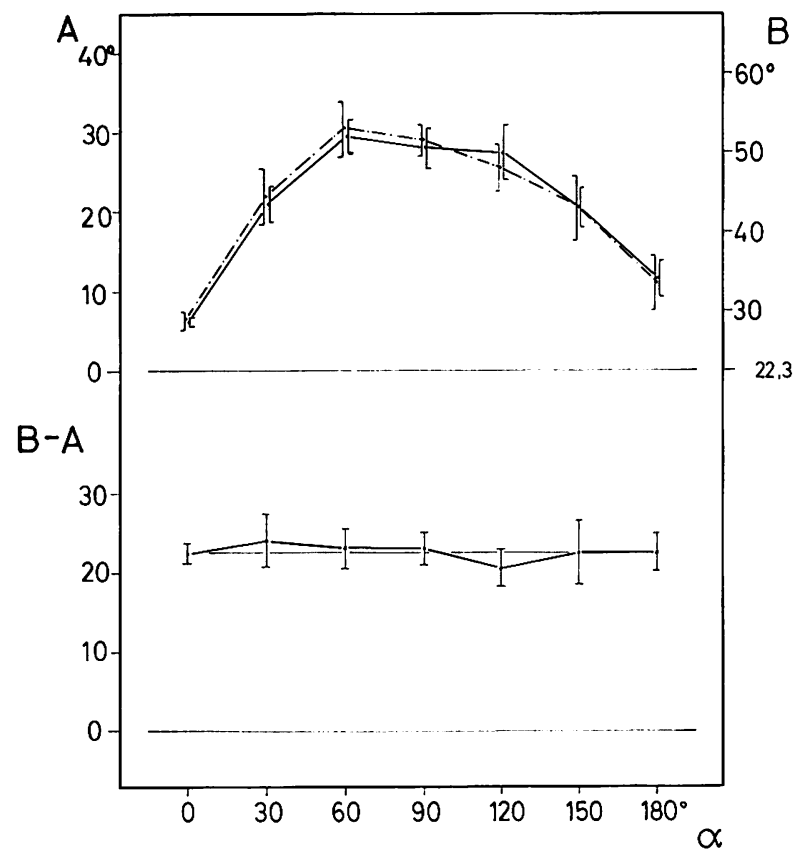

Fig. 10. Experimental support of feed-back autocompensation hypothesis in the perception of verticality (from BischoF and ScheErer, 1970). Comparison of ordinate (A: solid lines) and abscissa (B: broken lines) for extreme values of apparent vertical (cf. Fig. 9). Mean values of three subjects, with average variance of means shown by bars. $B$ scale shifted so as to accomplish maximal coincidence of curves. Evidently, B is dependent on head inclination (abscissa), whereas B-A is not

(2) Hypothesizing feed-back compensation (Fig. 8) yields quite different predictions. In this case the optic messages do not reach the filter mechanism before having undergone the (combined optic-vestibular) compensatory process that transforms them into the final coordinate system of apparent space. It is thus the apparent inclination of the four optical main directions (rather than their inclination with respect to a postural standard) that determines the partitioning of their spheres of influence. In other words, with feed-back compensation the apparent vertical, as represented by the luminous beam controlled by the subject, serves as the reference required for the validation of the optical main directions. Defined in this fashion, however, the reference is no longer invariant during a trial, and it varies, moreover, in a different way with different head inclinations. With feed- 
back compensation, consequently, the abscissa sections between extreme values in Fig. 6 would not be apportioned independent of head inclination. Only if we refer the stripe inclination at every moment to the position of the apparent vertical, i.e., if we project the extreme values, as in Fig. 9b, parallel to the diagonal broken lines, rather than perpendicularly, should we obtain an invariant partitioning of the abscissa.

Bischof and Scheerer (loc.cit.) could show, that, with this latter transformation carried out, the partitioning of ranges of influence among the four optical main directions in fact becomes invariant relative to head inclination (see Fig. 10). This indicates that the internal auto-compensatory system of visual perception of verticality is of the feed-back type.

\section{Optic-Vestibular Interaction and the Correction Principle}

\section{A. The Utilization of "Convergent Detection"}

The simultaneous occurrence of both (optical) auto- and (vestibular) heterocompensation in human vertical constancy sheds light on another peculiarity of perceptual information processing. Apparently, compensatory achievments are confined within the limits of precision of the mechanisms that provide the compensatory variable $s$. When, owing to possible shortcomings in information conveyance or computation, the compensatory variable does not exactly correspond to the interfering variable $\alpha$, then $s$ is unable to balance the effect of $a$ exactly, and the interference is under- or overcompensated. The $\mathrm{A}$ and $\mathrm{E}$ phenomena described above (see Fig. 2) are examples of this.

In order to minimize such errors, the organism often seeks to provide information about an interesting distal item by using, in parallel, a plurality of sensory channels which are susceptible to different kinds of disturbing effects. Thus, the probability of error can be reduced by "convergent detection", as it were, a possibility that has been repeatedly discussed in psychological literature (cf. especially BRunswik, 1934, 1940, 1956). For reasons that will be explained later (see p. 180), BIScHof $(1966 \mathrm{~b}$ ) has proposed the term "correction principle" for this method of perceptual information processing.

\section{B. Optic-Vestibular Equivalence}

Separate sensory data which provide information about one and the same distal issue, and which are, accordingly, exchangeable with respect to their biological significance to the organism, will be referred to in the following as "equivalent signals". In this respect, a remarkably close relationship exists between optical and vestibular messages: for every particular output of the vestibular organs there exists an equivalent optical signal-parameter; likewise, every motor or perceptual effect known to be controlled by vestibular inputs can also be elicited by proper optical excitation.

More particularly, stimulation of the semi-circular canals is equivalent to visual excitation produced by uniform movement of the entire stimulus field. The perceptual results of the latter are usually referred to as "induced movement" 
(Duncker, 1929; LINSchoten, 1952; cf. also Gibson, 1950, 1954); the corresponding motor reactions are known under the name of "optokinetic responses". The optical counterparts of stimulation of the otolith organs have been discussed in an earlier section (see pp. $166 \mathrm{ff}$.); their perceptual effect, viz., their influence on the apparent vertical, has been termed "directional induction" by KLEINT (1936), with obvious reference to DUNCKER. In labeling the corresponding motor reactions, it might be convenient to speak of "optostatic responses" in analogy to "optokinetics". The impairment of body balance while observing a slightly but uniformly slanted mountain meadow is an optostatic effect, as is the "dorsal light reaction" in fishes (voN HoLsT, 1950). The occurrence of optostatic eye countertorsion in man has been reported by GReenberg (1960) (cf. however Howard and Templeton, $1964 \mathrm{~b}$ ).

Note that optic and vestibular signals are not equivalent with respect to information concerning straight body movements. Here only the eye is able to convey reliable information (GIBSON, 1954), and not the vestibular apparatus, contrary to repeated speculations (e.g., by MAGNUS, 1924). Whether and how messages of the latter may yet play some role in this connection, will not be discussed here (cf. Bischof, 1966 c, p. $483 \mathrm{f}$ ).

\section{Incongruity of Equivalent Signals}

Like reconstruction processes, the method of convergent detection is also based on the utilization of redundancy - not, to be sure, within the domain of distal objects, but rather on the level of sensory messages referring to these objects: the organism tries to keep on the safe side by seeking information from different "warrantors". But what if those warrantors are at odds with each other; i.e., what if equivalent messages exhibit incongruity? In general there are three possible organismic reactions in such a situation; all three do also appear in the special case of optic-vestibular incongruity.

\section{1. "Compromise" Solution}

The most usual organic reaction encountered with optic-vestibular incongruity is the calculation of a weighted average of the competing messages. The weight factors involved in this type of information processing will be discussed below (see pp. 180ff.). Evidently, the results of the experiments of BischoF and ScheErer (1970), as depicted in Fig. 6, can be understood as compromise solutions of this type. Von Holst (1950) and BRAEmer (1957) obtained comparable results with fishes.

\section{2. "Alternative" Solution}

A second possibility is that the organism takes account of only one of the competing signals while entirely blocking the others. The dominance may or may not flip-flop between the signals concerned. Here, again, weight factors are likely to play a role. Effects of this kind may be encountered if very suggestive optic direction cues, for instance a (tilted) dummy room, are viewed in upright body position. Some subjects of KLEINT (1936) reported that under these circumstances the dummy room appeared to them alternately tilted and upright. 


\section{3. "Simultaneity" Solution}

Whereas the two previous solutions to the incongruity problem will always provide an unequivocal basis of orientation, there are cases in which the incompatible signals reach conscious perception simultaneously, without mutual suppression. It may be questioned, of course, whether we can speak of a "solution" here, as the resulting perceptual phenomenon is over-determined in a paradoxical way, unfit for being reacted to. If, for example, a subject remains stationary, surrounded by a dummy room that rotates slowly around a horizontal axis, he generally experiences his body at first to be somewhat tilted in the opposite direction; subsequently he feels that his body keeps rotating, yet that its position no longer changes : the experience of motion ("I am rotating with constant angular velocity") and the experience of position ("I never reach the head-down posture") break apart (Kleint, 1937; cf. also Duncker, 1929; Oppenheimer, 1935; Metzger, 1940,1954, p. 150). - Even in the absence of visual information, some subjects experience two possibilities of setting a luminous line to apparent verticality simultaneously under body tilt of about $150^{\circ}$. This would indicate a conflict within the postural cue system (FISCHer, 1930; Udo de HaEs and Schöne, 1969; Graybiel and Clark, 1962; Miller and Graybiel, 1966; cf. also below, p. 182).

\section{Error Detection and Error Correction}

The practice of obtaining information about the same item through parallel channels is in some measure analogous to that of modern communication technique, which uses, for conveying a message over a single channel, a number of symbols that exceeds the theoretically required minimum. Both methods utilize signal redundancy, and both do so for the sake of the advantage that in case of error the receiver is supplied with at least (1) a warning that an error is present, but perhaps also (2) with cues for its correction.

\section{Error Detection}

The receiving system can tell from certain irregularities in the signals received - in the case in point, from the incongruity of equivalent messages - at least that an error has occurred, although it may have no idea at which particular place. There is indication that the sensory systems react to this kind of "alarm" by forwarding only in a restricted form (with a proviso, as it were) the message likely to be erroneous. The corresponding phenomenal quality is often referred to by the subject with terms like "uncertain", "vague", "feeble", "faint", "unconvincing", "unreal", and the like (cf. MetzGer, 1954, pp. 109f.). From experiments with the "haunted swing", for example, it is known that under conditions of strong optic-vestibular ambiguity a weakening, even a loss, of phenomenal verticality may result; in the extreme case, the subject may become unable to assign the terms "up" and "down" to any direction of his phenomenal space (KLEINT, 1936, 1940).

A particularly vigorous reaction of the organism to error warnings due to incongruities within the optic-vestibular domain consists, according to many authors, in the phenomenon of vertigo. Indeed, certain distinct features of this response, like anxiety and release of primitive security reflexes (clinging), may 
well be understood as emergency measures in the face of threatening decomposition of space orientation. For more details, see the chapters F.VIII; IX; G.I. in this volume.

\section{Error Correction}

In certain communication systems the receiver may not only be informed, by inconsistencies in the message, that an error has occurred, but also where it is probably sited and what the original text most likely was. We have reason to believe that the method of convergent ascertainment in the perceptual system also works as an error-correcting routine in this sense. That is why we have proposed the term "correction principle" here.

Above (see p. 178) we introduced the notion of "weight factors" that control the relative power available to equivalent sensory messages when they compete with each other in the case of incongruity (cf. KLEINT, 1936). The evidence obtained up to now allows us to conjecture that those weight factors tend to be computed according to the following rule: The less a signal is likely to convey an erroneous message (i.e., the more and the better cues speak in favor of its reliability) the higher is it weighted in competition with contradicting equivalent signals (BRUnswIK, 1956; KLIX, 1962). Thus we may tentatively summarize the correction principle as follows: The organism reduces the probability of error in the perceptual processes by providing for equivalent messages through different sensory channels and then "relying" exclusively or preferably upon those whose validity is supported by the better cues.

\section{E. Determinants of the Optic-Vestibular Weight Ratio}

In his classical investigations on the equilibrium responses of fish during conflicting optic and vestibular stimulation, voN HoLST (1950) coined the term "statisch-optische Verhältniszahl" (translatable as "vestibular-optic weight ratio") to refer to a specific parameter that expresses the degree to which the vestibular righting-response prevails over a conflicting dorsal light reaction (cf. also Braemer, 1957). Von Holst defined this coefficient as the cotangent of the angle between the dorso-ventral axis of the fish and the plumb line, recorded under conditions of horizontal light incidence. For the results to be interpretable the angle had to be measured when the fish was in a state of physiological equilibrium, i.e., after possible postural reflexes had ceased. Because of the latter condition von HoLST's definition of the "vestibular-optic weight ratio" is suitable only for experimental situations in which the subject senses his body to be vertical. For perceptual experiments in which, by body fixation, every possible feed-back of the apparent vertical on body posture is blocked and in which, therefore, body inclination and apparent vertical do not necessarily correspond, a different way of defining the weight ratio is advisable. For reasons to be elucidated below (see p. 182), BISchoF and ScheERER (1970) suggest taking the average range of oscillation of the apparent vertical, under conditions of steady rotation of the optical pattern around the visual axis, as an index of the weight ratio discussed.

In distinction to von Holst's term, we feel it would be better to speak of an "opticvestibular weight ratio" here, since the value of the coefficient - the mean amplitude of oscillation in Fig. 6 - increases monotonically with optic predominance. 
The factors governing the optic-vestibular weight ratio (however defined) have not yet been thoroughly investigated, partly because for years authors have engaged in a fruitless debate as to which of the two sensory channels, the optical or the vestibular, is "prior" or "more basic" to the perception of the vertical, instead of taking for granted that both are important and simply asking how they interact (for a critical review of this discussion, see Gibsos, 1952).

1. As far as the optical determinants of the optic-vestibular weight ratio are concerned, we know this much: with labyrinthine stimulation constant, the induction of the apparent vertical by a striped field rises with the size of the latter and with the number of parallel contours within it; when patterns of higher complexity are used, the induction effect is enhanced according to the degree of their similarity to natural scenes (for references, see above, p. 160). These findings harmonize well with the correction principle, since each of the factors mentioned apparently makes it more probable - outside the laboratory situation - that the main direction of the retinal stimulus field coincides with the direction of gravity.

2. Less transparent is the biological advantage of certain intra-organismic factors influencing optic-vestibular competition. Between different fish species, for instance, considerable variation in the vestibular-optic weight ratio has been found by von HoLST (1950) and BraEmer (1957). In man, typological differences are asserted to occur: women and children give comparably more weight to visual stimuli than adult males, according to WITKIN et al. (1954). It is difficult to see what all this should have to do with the "reliability" of optical or vestibular cues. Actual needs, moods, attention and the like can also influence the perceptual response in optic-vestibular conflict situations. VoN Holst (1948) could demonstrate that the body inclination of laterally illuminated fishes is markedly enhanced when objects of high motivational valence (e.g., food) are presented. The animal, as it were, becomes "all eyes" and consequently rates the light source as a directional cue comparatively higher than he otherwise would, although the light source is not his object of attention at all and certainly has not become any more "reliable." The effect of light intensity upon the weight of optical directional cues (Curran and LANe, 1962) may be mentioned in this connection. Findings like these suggest that the correction principle should not be understood as a general postulate, but rather as a heuristic principle.

3. The vestibular-somesthetic influences upon the optic-vestibular weight ratio are, again, interpretable in "reliability" terms. According to observations of voN HoLsT (1950), shaking the water in an aquarium, simulating surf, is apt to enhance considerably the optical component with some fish species. In this experiment, the laterally illuminated animals inclined their bodies more and more towards the light source, only gradually returning to the previous position after the water movement had stopped. VoN HoLsT also noted that an increase in hydrostatic pressure tends to augment the weight of the vestibular component. This, too, can be understood teleonomically, since water pressure normally rises with depth and is thus positively correlated with the calmness of the water layer and, consequently, with the reliability of the vestibular positional messages.

The most important problem concerning vestibular control of the opticrestibular weight ratio is the dependence of the latter upon body inclination. 
Information about this dependence has been provided for head tilts up to $40^{\circ}$ by earlier authors (HofmanN, 1910; Vernon, 1935; Witkin and Asch, 1948; Witkin, 1949) and extended to $180^{\circ}$ by Bischof and Scheerer (1970) and SchöNE and Udo DE HAES (1971). According to the correction principle, the visual induction of the apparent vertical should be minimum in upright position, since with slight or no body tilt the precision of the statolith apparatus is maximal. This expectation was confirmed in all investigations cited. Additionally, however, one would predict a maximal visual induction effect in a body position of $150-180^{\circ}$, since in this range the A-deviation, the variance of the apparent vertical, the subjective uncertainty, and also the influence of various other directional cues, are all known to be maximal (cf. QuIx and ErJsvogel, 1929; BRown, 1961; Correta and Guedry, 1964; Schöne, 1964; Guedry, 1965; Benson and Bodin, 1966; Schöne and Udo de Haes, 1968, 1971; Udo de HaES and SchöNe, 1969; Udo DE HAES, 1970).

Actually, the results of SchöNE and Udo DE HAES (1971) seem to confirm this expectancy. They exposed to their subjects a stimulus pattern consisting of a single line and a striped field, both rigidly connected so that the stripes formed a fixed angle of either plus or minus 15 degrees with the line. The subject, that is, when adjusting the single line to his apparent vertical, had to move the striped field as well, which therefore kept appearing to him inclined by 15 degrees in clockwise, or counterclockwise direction. In both conditions, the settings for the apparent vertical differed, due to directional induction, and the angle between both settings turned out to be greatest with a body tilt of 150 degrees.

However, the authors call attention to their method being rather susceptible to the well-known effect (cf. p. 179) that the vestibular vertical can be equivocal with extreme body tilt. If, say, with $a=150^{\circ}$ the vestibular vertical has two different possible positions, it is difficult to tell from the data obtained by SсHÖNE and UDO DE HAES whether the visual induction of the apparent vertical was due to a flip-flop kind of effect, or to a greater tolerance of any one of both possible states against continuous deflection. This distinction can easier be made using the method of Bischof and ScheERER (1970). Actually, Fig. $6 \mathrm{f}$ (cf. p. 171) shows one case (lowest unbroken line) in which a temporary shift between two possible DC-states of the apparent-vertical might have occurred. Normally, however, there were no such shifts, and the optic-vestibular weight ratio, defined as the average range of oscillation, was most marked with body inclinations between 60 and 90 degrees (cf. Fig. 6). Surprisingly enough, the optic-vestibular weight ratio, when plotted against body tilt, rendered a curve that was highly correlated with the counter-torsion characteristic of the subject's eye (cf. Fig. 11).

Fig. 11. Mean range of oscillation of luminous beam setting ( $\psi=$ filled dots and solid lines) and ocular countertorsion ( $\rho=$ empty dots and broken lines), plotted against body tilt $(\alpha)$ for three Ss. Raw data and mean values (from BISchoF and ScHEERER, 1970). Ordinate scale ratio $\psi: \rho=1.48$ calculated such as to minimize square difference of means over all three Ss. Note that there is not only a satisfactory proportionality between $\psi$ and $\rho$ but that even the factor of proportionality can be taken to be the same in all three subjects: the $S$ with the highest amount of eye countertorsion $(\mathrm{Vp} \mathrm{H})$ also shows the widest oscillations of the apparent vertical in the presence of a rotating striped field. Considering the small number of Ss, the latter effect, of course, should not be generalized at the moment 


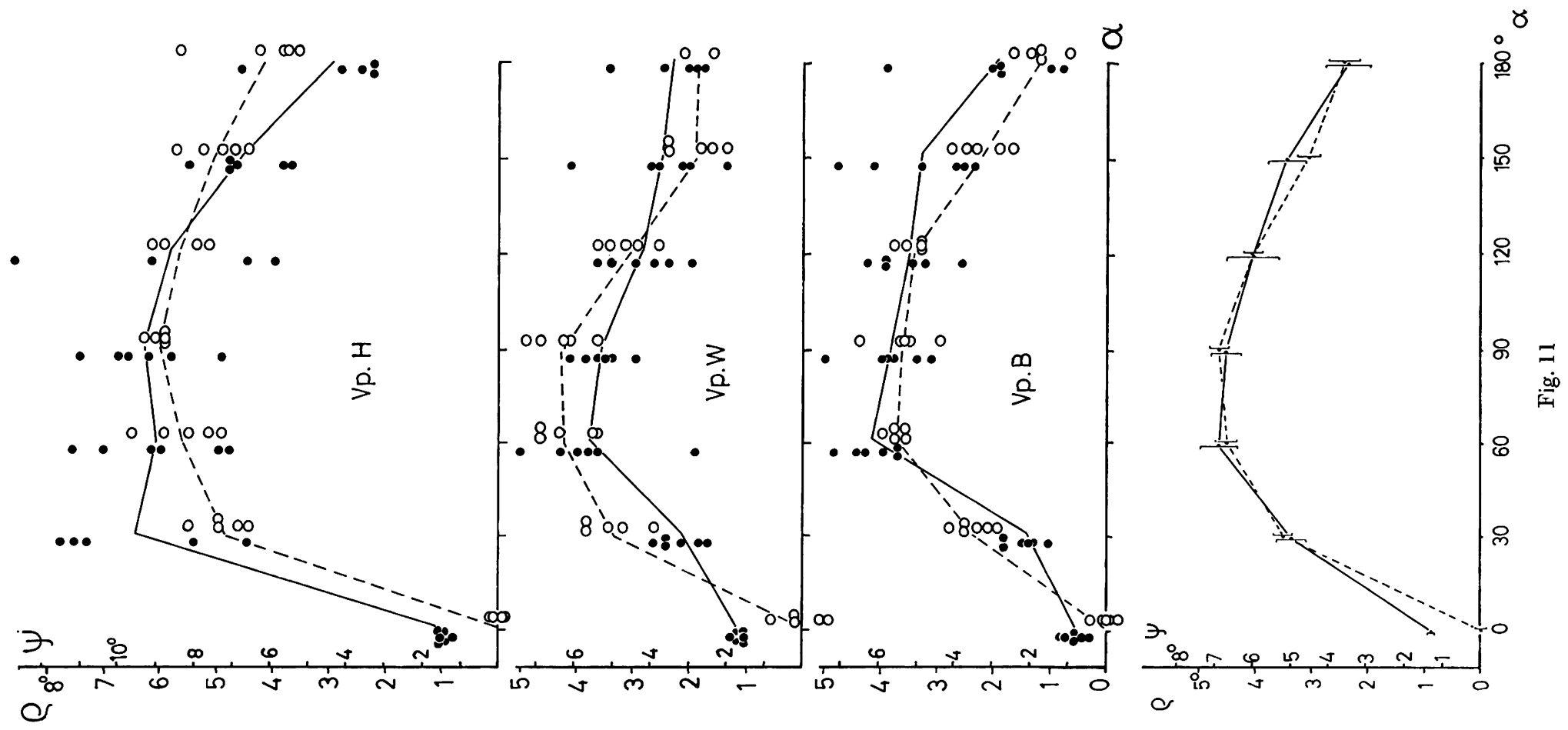


a)

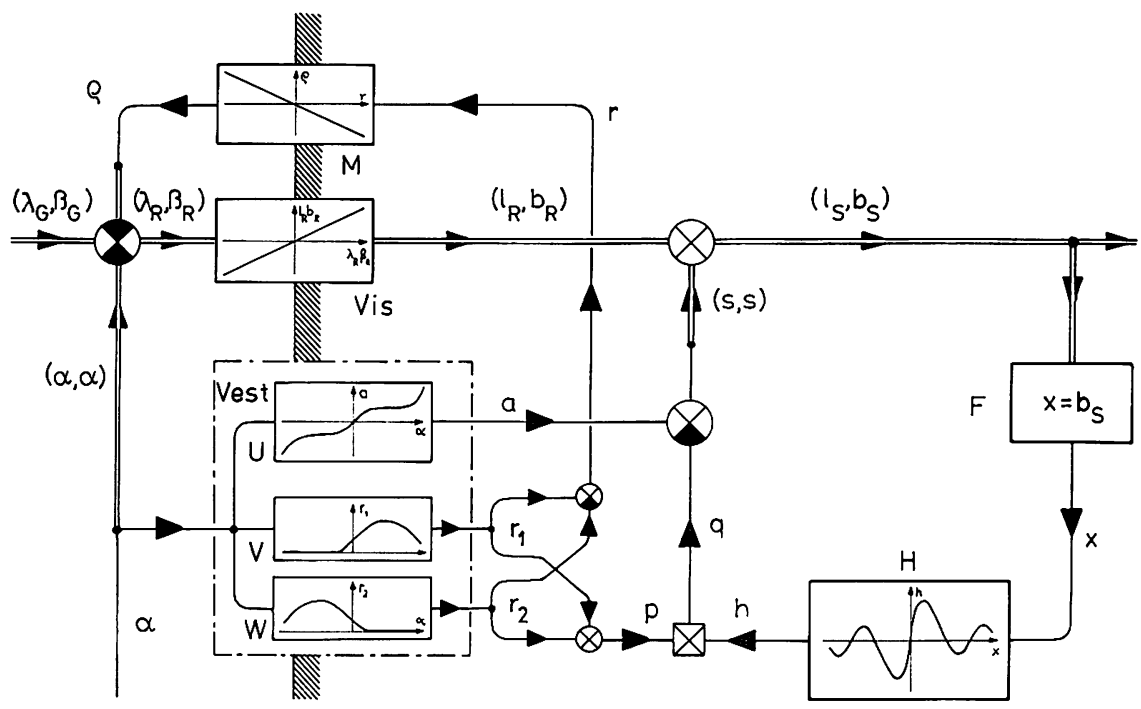

b)

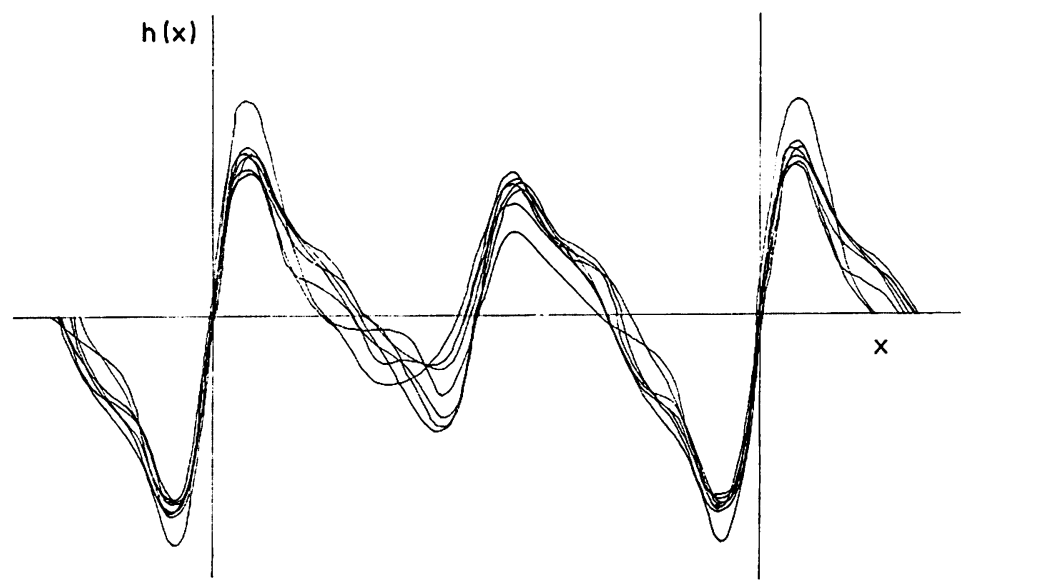

Fig. 12. a) Model of optic-vestibular orientation to the vertical. From Bisciof and Sche frer (1970). Double arrows represent two-component variables. Crossed square is multiplication symbol. For the remaining graphic symbols see the legends of Figs. 1 and 3. M: oculomotor system; Vis: visual system; Vest: vestibular system, split up into three subsystems $U, V$ and $W$, which can be distinguished functionally but must not necessarily be anatomically different. $\left(\lambda_{\mathrm{G}}, \beta_{\mathrm{G}}\right)$ : distal stimulus field, described by the inclination of light beam $(\lambda)$ and of primary axis of the striped field $(\beta)$ with respect to gravity (subscript $G) .\left(\lambda_{R}, \beta_{R}\right)$ : corresponding proximal stimulus field in retinal coordinates (subscript $R$ ), resulting from $\left(\lambda_{G}, \beta_{G}\right)$ by componentwise subtraction of head inclination $(a)$ and eye countertorsion $(\rho)$. $\left(l_{R}, b_{R}\right)$ : corresponding visual afference, operationally defined as a linear mapping of $\left(\lambda_{\mathrm{R}}, \beta_{\mathrm{R}}\right) .\left(l_{\mathrm{s}}, b_{\mathrm{s}}\right)$ : apparent inclination of light beam and striped field, issuing from $\left(l_{\mathrm{R}}, b_{\mathrm{R}}\right)$ by componentwise addition of a compensatory variable $(s, s)$. The latter can also be understood to act like a subjective frame of reference (subscript $\mathrm{S}$ ) into which $\left(l_{\mathrm{R}}, b_{\mathrm{R}}\right)$ is mapped to yield apparent contour inclinations. According to the model, $s$ results from arithmetic averaging of vestibular and optic direction cues, i.e., from a linear superposition of the vestibular tilt signal a (equivalent to $s$ in Fig. 3) and a quantity $q$ which itself is a product of a vestibular weight factor $p$ and an optical induction component $h$. The factor $p$ is operationally measured by the average range of oscillation $\psi$ as plotted in Fig. 11. It derives from the addition of two vestibular outputs $r_{1}$ and $r_{2}$, each of which reacts sinusoidally to head tilt to one side. The difference of $r_{1}$ and $r_{2}$ results in a command $(r)$ for eye countertorsion $(\rho)$. The apparent inclinations $\left(l_{\mathrm{s}}, b_{\mathrm{S}}\right)$ of the contours in the optic field are "filtered" by a mechanism F producing a quantity $x$ which 
The authors take this correlation as an indication that the optic-vestibular weight ratio as defined by them might be more than an arbitrary construction, and might refer to an actually existing physiological variable. ${ }^{5}$

Only in the upright position $\left(a=0^{\circ}\right)$ is there a significant difference between the two curves in Fig. 11, the countertorsion being zero in this case (and changing sign for negative abscissa values), whereas the mean range of oscillation does not vanish entirely (and remains positive when the body is inclined counterclockwise). This discrepancy is accounted for by BisCHOF and SCHEERER (loc.cit.) as being the effect of the subtraction or addition, respectively, of two separate otolith output components, one of which signals clockwise, the other counterclockwise head inclinations (for this distinction, cf. also MILLER, 1962, 1966, 1970; Terins, 1971).

Relying upon these assumptions and on systems-analytic elaborations previously cited, BISchoF and ScheERer summarize their theory about opticvestibular interaction in human perception of verticality in the flow diagram of Fig. 12. Because obtained from the investigation of only a limited number of subjects, this model can only claim the status of a preliminary hypothesis, the confirmation or refinement of which must be left to further research.

\section{References}

Adrian, E.D.: Discharges from vestibular receptors in the cat. J. Physiol. (Lond.) 101, 389 (1942).

Alexander, G., Barany, R.: Psychophysiologische Untersuchungen über die Bedeutung des Statolithenapparates für die Orientierung im Raume an Normalen und Taubstummen, nebst Beiträgen zur Orientierung mittels taktiler und optischer Empfindungen. Z. Psychol. 37, 312-362; 414-456 (1904).

ARNDTs, F.: Zur Frage nach der Lagewahrnehmung dienenden Sinnesfunktionen. Pflügers Arch. ges. Physiol. 204, 539-540 (1924).

Asch, S.E., Witrin, H.A.: Studies in space orientation. I. Perception of the upright with displaced visual fields. J. exp. Psychol. 38, 325 (1948a).

Asch, S.E., Witkin, H.A.: Studies in space orientation. II. Perception of the upright with displaced visual fields and with body tilted. J. exp. Psychol. 38, 455 (1948b).

Atrneave, F.: Some informational aspects of visual perception. Psychol. Rev. 61, 183-193 (1954).

AUBERT, H.: Eine scheinbare bedeutende Drehung von Objekten bei Neigung des Kopfes nach rechts oder links. Virchows Arch. 20, 381-393 (1861).

BECK, K.: Untersuchungen über den statischen Apparat von Gesunden und Taubstummen. Z. Psychol. 46, 362-378 (1912).

Bender, M.B., JunG, R.: Abweichungen der subjektiven optischen Vertikalen bei Gesunden und Hirnverletzten. Arch. Psychiat. Nervenkr. 181, 193-212 (1948).

Benjamins, C.E., Huizinga, E.: Untersuchungen über die Funktion des Vestibularapparates bei der Taube. Pflügers Arch. ges. Physiol. 217, 105 (1927).

5 Interpretable perhaps as the output of the utricles, which, due to their anatomical site. should yield afferent messages roughly proportional to the sine of head tilt (cf. vox HoLsT, 1950).

equals the apparent inclination of the striped field's primary axis. The optical induction quantity $h$, then, is a periodic function of $x . \mathrm{b}$ ) The model predicts that one single function $h(x)$ may be calculated from any given curve in Fig. 6 (see p. 170-171) by: 1. reassigning the ordinate values to the oblique co-ordinate system consisting of the diagonals and the abscissa in Fig. 6 ; 2. normalizing the transformed curve to the mean oscillation level; 3. dividing the resulting curve through its mean range of oscillation. Fig. $12 \mathrm{~b}$ shows that this prediction is ralid. Drawn are 6 curves calculated as described above from the mean-value curves for one Subject at 6 different body tilts. As is apparent, one single empirical curve $h(x)$ results. When $h(x)$ is inserted in block $H$ in Fig. $12 \mathrm{a}$, theoretical $\lambda_{\mathrm{G}}$-values yielding a permanent $l_{\mathrm{S}}=0$ can be computed; they are shown in white in Fig. 6 
Benson, A.J., Bodin, M.A.: Effect of orientation to the gravitational vertical on nystagmus following rotation about a horizontal axis. Acta oto-laryng. (Stockh.) 61, 517 (1966).

Beritofr, J.S. : Spatial orientation of man and animals. 22. Int. Kongr. Physiol. Sci. Excerpta Med. Int. Congr. Ser. 47, 3 (1962).

Beritoff, J.S.: Les mechanism nerveux de l'orientation spatiale chez l'homme. Neuropsychologia 1, 233 (1963).

Bertini, M.: Studio sulla natura dell'effeto "frame" nella percezione della verticale. Riv. Psicologia 58, 1-35 (1964).

BischoF, N.: Erkenntnistheoretische Grundlagenprobleme der Wahrnehmungspsychologie. In: Handbuch der Psychologie, Bd. 1/I, Bewußtsein und Wahrnehmung. W. MetzGer and H. Erke, Eds. pp. 21-78. Göttingen: Verlag f. Psychologie 1966a.

Bischof, N.: Psychophysik der Raumwahrnehmung. Ibid. P. 307-408, 1966 b.

Bischof, N.: Stellungs-, Spannungs- und Lagewahrnehmung. Ibid. P. 409-497, 1966 c.

Bischof, N., Scheerer, E.: Systemanalyse der optisch-vestibulären Interaktion bei der Wahrnehmung der Vertikalen. Psychol. Forsch. 34, 99-181 (1970).

BittermanN, M.E., Worchel, P.: The phenomenological vertical and horizontal in blind and sighted subjects. Amer. J. Psychol. 66, 588 (1953).

Boring, E.G.: Visual perception as invariance. Psychol. Rev. 59, 141. The Gibsonian visual field. Psychol. Rev. 59, 246 (1952).

BraEmer, W.: Verhaltensphysiologische Untersuchungen am optischen Apparat bei Fischen. Z. vergl. Physiol. 39, 374-398 (1957).

Braemer, W.: A critical review of the sun-azimuth hypothesis. Cold Spr. Harb. Symp. quant. Biol. 15, 413 (1960).

Brandt, U., Fludr, E.: Postural perceptions and compensatory displacements of the eye in respect to a presented force field. Acta oto-laryng. (Stockh.) 62, 252-264 (1966).

Brandt, U., FuUur, E.: Postural perceptions and eye displacements during the variation of a force field acting in the midfrontal plane. Acta oto-laryng. (Stockh.) 63, 49-64 (1967).

Brecher, G. A., Schubert, G.: Utber optische Lokalisation und Augenstellung bei Vor-Rückwärtsneigung oder exzentrischer Rotation des Körpers. Z. Sinnesphysiol. 65, 1 (1934).

Brown, L.: Orientation to the vertical during water immersion. Aerospace Med. 32, 209-217 (1961).

BRunswik, E.: Wahrnehmung und Gegenstandswelt. Leipzig, Wien: Deuticke 1934.

BRUnswik, E.: Thing constancy as measured by correlation coefficients. Psychol. Rev. 47, $68(1940)$.

Brunswik, E.: Perception and the representative design of psychological experiments. Berkeley: University of California Press 1956.

BRunswiK, E., Kardos, L.: Das Duplizitätsprinzip in der Theorie der Farbenwahrnehmung. Z. Psychol. 111, 315 (1929).

BüHLER, K.: Die Erscheinungsweisen der Farben. Jena: 1922.

Carpenter, R.H.S., Blakemore, C.: Interactions between orientations in human vision. Exp. Brain Res. 18, 287-303 (1973).

Clark, B., Graybiel, A.: Perception of the visual horizontal in normal and labyrinthine defective subjects during prolonged rotation. Amer. J. Psychol. 79, 608-612 (1966a).

Clark, B., Graybiel, A.: Factors contributing to the delay in the perception of the oculogravic illusion. Amer. J. Psychol. 79, 377-388 (1966 b).

Colenbrander, A.: Eye and otoliths: A centrifuge study on the ocular response to otolith stimulation. Aeromed. Acta (Soesterberg) 9, 45-91 (1963-1964).

Coltheart, M.: Visual feature-analyzers and after-effects of tilt and curvature. Psychol. Rev. 78, 114-121 (1971).

Correia, M.J., GuEDry, F.E.: Influence of labyrinth orientation relative to gravity on responses elicited by stimulation of the horizontal semicircular canals. U.S. Naval School of Aviat. Med. N.A.S.A. joint report, Pensacola, Fla., 1964.

Correia, M.J., Hixson, W.C., Nrven, J.: Otolith shear and the visual perception of force direction. Discrepancies and a proposed resolution. Nami-951, Nasa Order R-93. Pensacola, Fla: Naval Aerospace Med. Inst., 1965.

Culbert, S.S.: Directional after-effects following systematic distortion of the visual field. J. Psychol. (Provincetown) 37, 81-93 (1954). 
Curran, C.R., LANE, H.L.: On the relation of some factors that contribute to estimates of verticality. J. exp. Psychol. 64, 295 (1962).

DAY, R.H., WADE, N.J.: The reference for visual normalization. Amer. J. Psychol. 82, 191-267 (1969).

Derwort, A.: Utber vestibulär induzierte Dysmorphopsien. Dtsch. Z. Nervenheilk. 170, 295-325 (1953).

Duncker, K.: Über induzierte Bewegung. Psychol. Forsch. 12, 180 (1929).

Fischer, M.H.: Messende Untersuchungen über die Gegenrollung des Auges und die Lokalisation der scheinbaren Vertikalen bei seitlicher Neigung des Kopfes, des Stammes und des Gesamtkörpers. I. Neigungen bis zu 40․ Graefes Archiv 118, 633-680 (1927).

Fischer, M.H.: Messende Untersuchungen über die Gegenrollung der Augen und die Lokalisation der scheinbaren Vertikalen bei seitlicher Neigung des Gesamtkörpers bis zu $360^{\circ}$. II. Untersuchungen an Normalen. Graefes Archiv 123, 476-508 (1930a).

Fischer, M.H.: III. Untersuchungen an einem Ertaubten mit Funktionsuntüchtigkeit beider Vestibularapparate und einem einseitig Labyrinthlosen. Graefes Archiv 123, $509-531(1930 \mathrm{~b})$.

FluUr, E., Mellström, A.: Utricular stimulation and oculomotor reactions. Laryngoscope (St. Louis) 53, 1701-1712 (1970a).

FluUR, E., Mellström, A.: Saccular stimulation and oculomotor reactions. Laryngoscope (St. Louis) 53, 1713-1721 (1970 b).

Garten, S.: Ưber die Grundlagen unserer Orientierung im Raum. Abh. Math. Phy. Klasse, Sächs. Akad. 36, 431 (1920).

Geissler, H.G.: Zur Analyse adaptiver Prozesse bei der Orientierung im Raum. Z. Psychol. 171, (1965).

GeLB, A.: Die psychologische Bedeutung pathologischer Störungen der Raumwahrnehmungen. Ber. 9. Kongr. f. exp. Psychol. München. Jena 23-80, 1926.

Gibson, J.J.: Adaptation, after-effect, and contrast in the perception of tilted lines. II. Simultaneous contrasts and the areal restriction of the after-effect. J. exp. Psychol. 20, 553-569 (1937a).

Grbson, J.J.: Adaptation with negative after-effects. Psychol. Rev. 44, 222-244 (1937 b).

Grbson, J.J.: The perspective of the visual world. Boston: Houghton Mifflin Comp. 1950.

Gibson, J.J.: The relation between visual and postural determinants of the phenomenal vertical. Psychol. Rev. 59, 370-375 (1952).

Gibson, J.J.: The visual perception of objective motion and subjective movement. Psychol. Rev. 61, 304 (1954).

Gibson,J.J.:The senses considered as perceptual systems. Boston: Houghton Mifflin Comp. 1966.

Gibson, J.J., Mowrer, O.H.: Determinants of the perceived vertical and horizontal. Psychol. Rev. 45, 300 (1938).

Gibson, J.J., RADNER, M.: Adaptation, after-effect and contrast in the perception of tilted lines. J. exp. Psychol. 20, 452-467; 553-569 (1937).

GIRotTI, G.: La percezione dello spazio in rapporto alla neuropatologia. I. Determinazione della verticale visiva e del vertice acustico. Arch. Psicol. Neurol. Psichiat. 24, 175-336 (1963).

GIRotTi, G., Bordogna, A.: La determinazione della verticale e del piano mediano visivi nelle compressioni vestibulari. Riv. Psicologia 57, 301-339 (1963).

Graybiel, A., Clark, B.: Perception of the horizontal or vertical with head upright, on the side, and inverted under static conditions, and during exposure to centripetal force. Aerospace Med. 33, 147-155 (1962).

Graybiel, A., Mrller, E.F.II, Newsom, B.D., Kennedy, R. S.: The effect of water immersion on perception of the oculogravic illusion in normal and labyrinthine-defective subjects. Acta oto-laryng. (Stockh.) 65, 599-610 (1968).

Greenberg, G.: Visual induction of eye torsion, as measured with an after-image technique, in relation to visual perception of the vertical. Ph.D.Diss. Duke Univ., 1960.

GUEDRY, F.E.: Orientation of the rotation-axis relative to gravity: its influence on nystagmus and the sensation of rotation. Acta oto-laryng. (Stockh.) 60, 30 (1965).

HALPERn, L.: Sensorimotor induction in disturbed equilibrium. Arch. Neurol. Psychiat. (Chic.) 62, 330-354 (1949). 
Hasegawa, T.: Labyrinthreflexe nach Abschleuderung der Otolithenmembranen. Pflügers Arch. ges. Physiol. 236, 589 (1935).

Hofmann, F.B.: Über den Einfluß schräger Konturen auf die optische Lokalisation bei seitlicher Kopfneigung. Pfügers Arch. ges. Physiol. 136, (1910).

Hofmann, F.B., Bielschowsky, A.: Über die Einstellung der scheinbaren Horizontalen und Vertikalen bei Betrachtung eines von schrägen Konturen erfüllten Gesichtsfeldes. Pflügers Arch. ges. Physiol. 126, 453-475 (1909).

HoLsT, E. voN: Quantitative Untersuchungen über Umstimmungsvorgänge im Zentralnervensystem. I. Der Einfluß des "Appetits" auf das Gleichgewichtsverhalten bei Pterophyllum. Z. vergl. Physiol. 31, 134 (1948).

Holst, E. von: Die Arbeitsweise des Statolithenapparates bei Fischen. Z. vergl. Physiol. 32, 60-120 (1950).

Holst, E. von, Griesebach, E.: Einfluß des Bogengangssystems auf die "subjektive Lotrechte" beim Menschen. Naturwissenschaften 38, 67-68 (1951).

Holst, E. von, Mittelstaedt, H.: Das Reafferenzprinzip. Naturwissenschaften 37, 464 (1950).

Howard, I.P., Templeton, W.B.: The effect of steady fixation on the judgement of relative depth. J. exp. Psychol. 16, 193-203 (1964a).

Howard, I.P., Templeton, W.B.: Visually-induced eye torsion and tilt adaptation. Vision Res. 4, 433-437 (1964b).

Howard, I.P., Templeton, W.B.: Human spatial orientation. New York: Wiley 1966.

Hubel, D.H., Wiesel, T.N.: Receptor fields of single neurons in the cat's striate cortex. J. Physiol. (Lond.) 148, 574 (1959).

Huizinga, E.: The physiological and clinical importance of experimental work on the pigeon's labyrinth. J. Laryng. 69, 260 (1955).

Jongkess, L. B. W.: On the function of the sacule. Acta oto-laryng. (Stockh.) 38, 18-26 (1950).

JongKeES, L.B.W.: Some remarks on the function of the vestibular organ. Reports of the Institute of Laryng. Otol. 2, 1 (1952).

Kardos, L.: Dingfarbenwahrnehmung und Duplizitätstheorie. Z. Psychol. 108, 240 (1928).

Kardos, L.: Die "Konstanz" phänomenaler Dingmomente. In: E. Brunswik Ed. Beiträge zur Problemgeschichte der Psychologie (Bühler-Festschrift). Jena: 1929.

KellogG, R.S.: Dynamic counterrolling of the eye in normal subjects and in persons with bilateral labyrinthine defects. NASA Sp-77, 195-202 (1965).

Kleint, H.: Versuche über die Wahrnehmung. Z. Psychol. 138, 1 (1936); 140, 109 (1937); 141, 9 (1937); 142, 259 (1938); 143, 299 (1938); 148, 145 (1940); 149, 31 (1940).

KLIx, F.: Elementaranalysen zur Psychophysik der Raumwahrnehmung. VEB Dtsch. Verlag d. Wissensch., Berlin, 1962.

KLopp, H.W.: Über die Entwicklung und den Abbau des aufrechten Bildes. Fortschr. Neurol. Psychiat. 24, 27 (1956).

KöHLer, W., Wallach, H.: Figural after-effects. Proc. Amer. Phil. Sci. 88, 269-357 (1944).

Koffix, K.: Principles of Gestalt Psychology. Routledge and Kegan Paul: London, 1935.

KoHLER, I.: Úber Aufbau und Wandlungen der Wahrnehmungswelt. Sitzber. Österr. Akad. Wiss. 227, Wien, 1951.

Kohler, I.: Umgewöhnung im Wahrnehmungsbereich. Die Pyramide 3, 92 (1953).

Kohler, I.: Interne und externe Organisation in der Wahrnehmung. Psychol. Beitr. 6, 426 (1961).

Linschoten, J.: Experimentelle Untersuchung der sogenannten induzierten Bewegung. Psychol. Forsch. 24, 34-92 (1952).

Lowenstein, O.: Labyrinth and equilibrium. In: Physiol. Mechanisms in Animal Behav. Soc. exp. Biol. Symp. IV. Cambridge: Univ. Press 1950.

Lowenstein, O., Roberts, T.D.M.: The equilibrium function of the otolith organs of the Thornback Ray (Raja clavata). J. Physiol. (Lond.) 110, 392 (1950).

LoRenz, K.: Gestaltwahrnehmung als Quelle wissenschaftlicher Erkenntnis. Z. exp. angew. Psychol. 6, 118 (1959).

MacCorquodale, K., Meehl, P.E.: On a distinction between hypothetical constructs and intervening variables. Psychol. Rev. 55, 95-107 (1948).

McFarland, J.H., Clarkson, F.: Perception of orientation: Adaptation to lateral body-tilt. Amer. J. Psychol. 79, 265-271 (1966). 
MacKay, D.M.: Cerebral organization and the conscious control of action. In: Brain and conscious experience. J.C. Eccles, Ed. pp. 422-445, Berlin-Heidelberg-New York: Springer 1966.

MCNally, W.J.: Five lectures on the physiology of the ear. Ann. Otol. 38, 1180 (1929).

Magnus, R.: Körperstellung. Berlin: Springer 1924.

Mann, C.W.: Visual factors in the perception of verticality. J. exp. Psychol. 44, 460-464 (1952a).

Mann, C.W.: An analysis of the oculogyral effect. J. Aviat. Med. 23, 246-253 (1952 b).

Maxwell, S.S.: Labyrinth and Equilibrium. Philadelphia-London: 1923.

MetZGer, W.: Zur anschaulichen Repräsentation von Rotationsvorgängen und ihre Deutung durch Gestaltkreislehre und Gestalttheorie. Z. Sinnesphysiol. 68, 261 (1940).

Metzger, W.: Psychologie. Darmstadt: Steinkopff $1954^{2}$; $1968^{3}$.

Meyer zum Gottesberge, A., Plester, D.: Nachweis der statischen Funktion des Sacculus beim Menschen. Arch. Ohr.-, Nas.-, u. Kehlk.-Heilk. 185, 254-258 (1965).

Miller, E.F.II.: Counter-rolling of the human eyes produced by head tilt with respect to gravity. Acta oto-laryng. (Stockh.) 54, 479-501 (1962).

Miller, E.F.II.: Ocular counter-rolling. In: R.J. Wolfson, Ed. The vestibular system and its diseases. Philadelphia: Univ. of Pennsylvania Press, 229-241, 1966.

MILLER, E.F.II.: Evaluation of otolith organ function by means of ocular counter-rolling measurements. In: J. Stahle, Ed. Vestibular function on earth and in space. Oxford: Pergamon Press, 97-111, 1970.

Miller, E.F.II., Graybiel, A.: A comparison of ocular counter-rolling movements between normal persons and deaf subjects with bilateral labyrinthine defects. Ann. oto-rhinolaryng. 72, 885 (1963).

Miller, E.F.II., Graybiel, A.: Role of the otolith organs in the perception of horizontality. Amer. J. Psychol. 79, 24-37 (1966).

Mittelstaedt, H.: The analysis of behavior in terms of control systems. In: B. Schaffiner, Ed. Group Processes. Transactions of the 5. Conf. of the J. Macy Found. New York 45, 1960.

Mittelstaedt, H.: Basic solutions to a problem of angular orientation. In: R.F. Reiss, Ed. Neural Theory and Modeling, 259-272. Stanford Univ. Press 1964.

Mittelstaedt, H.: Grundprobleme der Analyse von Orientierungsleistungen. Jahrb. d. MaxPlanck-Ges. p. 121, 1966.

Morant, R.B., Aronoff, J.C.: Starting position, adaptation, and visual framework as influencing the perception of verticality. J. exp. Psychol. 71, 684-686 (1966).

Morant, R.B., Beller, H.K.: Adaptation to prismatically rotated visual fields. Science 148, $530(1965)$.

Morant, R.B., Harris, J.: Two different aftereffects of disposure to visual tilts. Amer. J. Psychol. 78, 218-226 (1965).

Morant, R.B., Mistovich, M.: Tilt after-effects between the vertical and horizontal axes. Percept. Mot. Skills 10, 75-81 (1960).

MüLLen, G.E.: Úbet das Aubertsche Phänomen. Z. Sinnesphysiol. 49, 109-246 (1916).

NaYlor, G.F.: Effects of stress on the perception of direction. Australian J. Psychol. 15, $17-28(1963)$.

NaYlor, G.F.K.: Subjective judgements of the vertical: An estimate of their nature and consistency. Australian J. Psychol. 17, 188-192 (1965).

ОншакI, S.: An investigation of figural adaptation: a study within the framework of sensorytonic field theory. Amer. J. Psychol. 74, 3-16 (1961).

Oppenheimer, E.: Optische Versuche über Ruhe und Bewegung. Psychol. Forsch. 20, 1-46 (1935).

Passey, G.E.: The perception of the vertical. IV. Adjustment to the vertical with normal and tilted visual frames of references. J. exp. Psychol. 40, 738-745 (1950).

Perlman, H. B.: The saccule, observations from a differentiated reinforced area of the saccular wall in man. Acta oto-laryngol. (Stockh.) 32, 678 (1940).

Quix, F.H., Eissvogel, M.H.: Experimente über die Funktion des Otolithenapparates beim Menschen. Z. Hals-, Nas.- u. Ohrenheilk. 23, 68-96 (1929). 
SchöNe, H.: Úber den Einfluß der Schwerkraft auf die Augenrollung und auf die Wahrnehmung der Lage im Raum. Z. vergl. Physiol. 46, 57-87 (1962).

ScHöNE, H.: On the Role of gravity in human spatial orientation. Aerospace Med. 35, 764 (1964).

Schöne, H., Parker, D.E.: Inversion of the effect of increased gravity on the subjective vertical. Naturwissenschaften 54, 288-289 (1967).

Schöne, H., Parker, D. E., Mortag, H.G.: Subjective vertical as a function of body position and gravity magnitude. Naturwissenschaften 54, 288 (1967).

SchöNe, H., Udo DE Haes, H.: Perception of gravity-vertical as a function of head and trunk position. Z. vergl. Physiol. 60, 440-444 (1968).

Schöne, H., Udo de HaEs, H.: Space orientation in humans with special reference to the interaction of vestibular, somaesthetic and visual inputs. Biokybernetik 3, 172-191 (1971).

SchNeIDER, C.W., Bartley, S.H.: A study of the effects of mechanically induced tension of the neck muscles on the perception of verticality. J. Psychol. (Provincetown) 54, 245-248 (1962).

StiGler, R.: Versuche über die Beteiligung der Schwereempfindung an der Orientierung des Menschen im Raume. Pflügers Arch. ges. Physiol. 148, 573-584 (1912).

Sutherland, N.S.: Figural after-effects and apparent size. Quart. J. exp. Psychol. 13, $222-228$ (1961).

SzentágothaI, J.: Die Rolle der einzelnen Labyrinthreceptoren bei der Orientation von Augen und Kopf im Raume. Budapest: Akadémiai Kiado 1952.

TAIT, J.: Is all hearing cochlear. Ann. Otol. (St. Louis) 41, 681 (1932).

TERINS, J.: Counter-rolling of the eyes in some unilateral vestibular disorders. In: J. STAHLE, Ed. Vestibular function on earth and in space. Oxford: Pergamon Press, 109-113, 1971.

UdO DE HAES, H.: Stability of apparent vertical and ocular coutertorsion as a function of lateral tilt. Perception \& Psychophysics 8, 137-142 (1970).

Udo DE HAES, H., SCHÖNE, H.: Interaction between statolith organs and semicircular canals on apparent vertical and nystagmus. Acta oto-laryng. (Stockh.) 69, 25-31 (1970).

Vernon, M.D.: The perception of inclined lines. Brit. J. Psychol. 25, 186 (1935).

Versteegh, L.: Ergebnisse partieller Labyrinthexstirpation bei Kaninchen. Acta oto-laryng. (Stockh.) 11, 393 (1927).

WALSH, E.G.: Perception of linear motion following unilateral labyrinth ectomy: variation of threshold according to the orientation of the head. J. Physiol. (Lond.) 153, 350 (1960).

WALSH, E.G.: Role of the vestibular apparatus in the perception of motion on a parallel swing. J. Physiol. (Lond.) 155, 506 (1961).

Werner, H., Wapner, S., Chandler, K.A.: Experiments on sensory-tonic field theory of perception. II. Effect of supported and unsupported tilt of the body on the visual perception of verticality. J. exp. Psychol. 42, 346 (1951).

Wertheimer, M.: Experimentelle Studien über das Sehen von Bewegung. Z. Psychol. 61, 161-265 (1912).

Wirkin, H.A.: The nature and importance of individual differences in perception. J. Personality 18, 145 (1949a).

WitkIN, H.A.: Sex differences in perception. Trans. N.Y. Acad. Soc. 12, 22 (1949 b).

Witkin, H.A., Asch, S.E.: Studies in space orientation. III. Perception of the upright in the absence of a visual field. J. exp. Psychol. 38, 603 (1948a).

Witkin, H.A., AscH, S.E.: Studies in space orientation. IV. Further experiments on perception of the upright with displaced visual fields. J. exp. Psychol. 38, 762 (1948b).

Witkin, H.A., Lewis, H.B., Hertzman, M., Machover, K., Meissner, P.B., Wapner, S.: Personality through perception. New York: Haper 1954.

Woellner, R.C., Graybiel, A.: Counterrolling of the eyes and its dependence on the magnitude of gravitational or inertial force acting laterally on the body. J. appl. Physiol. 14, 632-634 (1959).

Woon, R.W.: The "haunted-swing" illusion. Psychol. Rev. 2, 277-278 (1895).

Young, H.H.: Personality test correlates of orientation to the vertical: A test of Witkin's Field dependency hypothesis. J. abnorm. soc. Psychol. 59, 188-192 (1959).

Youna, H.H., MeIrI, J.L.: A revised dynamic otolith model. Aerospace Med. 39, 606-608 (1968). 


\section{Author Index}

Page numbers in italics refer to the bibliography

Aarons, L., s. Lachman, J. 365, | Angyal, A., Blackman, N. 365, 367

Abels, H. 369, 370, 383, 425, 443

Abend, W. K., s. Fernández, C. 532,575

Ackerman, U., Johnson, W. H., Thomas, E. L. 399, 402

Ades, H. W., s. Engström, H. 70,142

Ades, H. W., s. Gernandt, B. 434,445

Ades, H., s. Mickle, W. 7, 8, 14.9

Adey, W. R., Kado, R. T., Rhodes, J. M. 261, 263

Adrian, E. D. 69, 71, 136, 165, $185,285,315,423,443,452$, $454,460,464,484,517,573$

Ajuriaguerra, J. de, s. Hécaen, H. 218, 230

Akert, K., s. Scollo-Lavizzari, G. 612,620

Albe-Fessard, D., Donaldson, J. M. L. 609,615

Alden, F. D., Horton, M. O., Caldwell, G. M. 357

Alessi, D. 213, 229

Alexander, G., Bárány, R. 164, $185,435,443$

Alexander, S. J., Cotzin, M., Hill, C. J., Jr., Ricciuti, E. A., Wendt, G. R. 262, 263

Alltucker, D. S., s. Gualtierotti, T. $452,461,464,486$

Ambler, R. K., Guedry, F. E. 126,136

Ambler, R. K., s. Guedry, F. E. $116,126,129,130,131,144$

Ambler, R. K., s. Mann, C. W. 85,148

Ames, A. 566, 573

Anderson, A., s. Henriksson, N. G. 36,145

Andersson, S., Gernandt, B. 7, 136

Andersson, S., Nilsson, A., Ruuth, E., Smith, G. 36, 110,136 366

Ansom, B. J. 573

Aoki, M., s. Tokita, T. 355

Aoki, S., s. Tokita, T. 355

Aokia, S., s. Fukuda, T. 376, 377,385

Arlaschenko, N. I., Bokhov, B. B., Busygin, V. Ye., Volokhova, N. A., Grigoryev, Yu. G., Polyakov, B. I., Farber, Yu. V. 353

Arndts, F. 88, 136, 164, 185

Arnoult, M. 22, 136

Aronoff, J. C., s. Morant, R. B. 160,189

Aronson, L., s. Spiegel, E. A. 477,489

Arslan, M. 222, 229

Arslan, M., Molinari, J. A. 8, $136,475,484$

Arx, S. V., s. Pfaltz, C. R. 378, 387

Asch, S. E., Witkin, H. A. 160, 162,185

Asch, S. E., s. Witkin, H. A. $160,162,182,190$

Aschan, G. 376, 379, 383, 406, $409,410,419,425,426,443$

Aschan, G., Bergstedt, M. 62, $136,419,443$

Aschan, G., Bergstedt, M., Goldberg, L. 307, 315

Aschan, G. M., Bergstedt, M., Goldberg, L., Laurell, L. 307,315

Aschan, G., Bergstedt, M., Stahle, J. 200, 229

Aschan, G., Finer, B. L., Hagbarth, K. E. 365,366

Aschan, G., Nylén, C. O., Stahle, J., Wersäll, R. 29, 136, 429, 430, 443

Aschan, G., s. Grant, G. 205, 230

Aschoff, J. C. 217, 229

Aschoff, J. C., Cohen, B. 587, $597,598,615$
Aschoff, J. C., Conrad, B., Kornhuber, H. H. 199, 208, $210,229,587,606,615$

Aschoff, J. C., s. Kornhuber, H. H. $600,602,610,618$

Atema, J., s. Von Baumgarten, R. J. 558, 559, 560, 580

Attneave, F. 166, 185

Atwood, R. P., s. Braitenberg, V. 604, 615

Aubert, H. 82, 86, 136, 160, $161,185,241,263$

Aubert, H., Delage, Y. 408, $410,418,419,433,443$

Aubry, M., s. Claude, H. 361, 365,366

Austin, G. M., s. McCouch, G. P. 459,461

Auxter, D. M. 357

Azzena, G. B. 460, 460, 470, 481,484

Azzena, G. B., Giretti, M. L., Deriu, P. L. 475,484

Babinski, J., Weill, G. A. 272, 278

Babiyak, V. P., s. Kurashvili, A. Ye. 303,318

Babkin, B. P. 400

Babkin, B. P., Bornstein, M. B. 400,402

Babkin, B. P., Divorkin, S. 400, 402

Babskii, E. B., Gurfinkel, V. S., Romel, E. L. 359

Bach, L. 361, 366

Bader, W., Kornhuber, H. H. $222,229,587,615$

Baker, A. B. 227, 229

Baker, R. G., Mano, N., Shima$\mathrm{zu}$, H. 458, 460

Bakhvalova, T. D. 300,315

Baldenweck, L. 269, 271, 278

Baldrighi, G., s. Von Baumgarten, R. J. 558, 559, 560, 580

Bárány, J. W., Ismail, A. H., Manning, K. R. 359 
Bárány, R. 62, 93, 136, 220,|Batini, C., Moruzzi, G., Pom$229,269,270,271,274,276$, $278,303,315,353,357,361$, $366,369,383,405,410,415$, $418,421,427,444,451,460$, $483,484,590,615$

Bárány, R., Wittmaack, K. $270,271,278$

Bárány, R., s. Alexander, G. $164,185,435,443$

Barber, H. O., Wright, G. 201, $206,229,365,366$

Barbey, E. 353

Barcroft, H., Edholm, O. G. 393,402

Bard, P. $610,612,615$

Bard, P., Orias, O. 610, 615

Bard, P., Woolsey, C. N., Snider, R. S., Mountcastle, V. B., Bromiley, R. B. 607, 615

Bard, P., s. Tyler, D. B. 389, $390,391,393,404$

Barlow, J. S. 6, 7, 8, 90, 136, $495,496,500,573$

Barnes, G. R. 75, 112, 115, 136, $290,312,315,315$

Barnes, G. R., s. Benson, A. J. $111,112,137,290,311,312$, 316

Barness, C. D., Pompeiano, 0. 585,615

Barness, C. D., s. Pompeiano, 0. 585, 619

Barnothy, I. M., s. Torok, N. 220,232

Baron, J. 353

Baron, J. B. 356

Baron, J. B., s. Soulairac, A. 356

Barré, J. A. 436, 444

Barrera, S. E., s. Northington, P. $471,472,488$

Barrett, G. V., Thorton, C. L. 119,136

Barry, W., s. Melvill Jones, G. $45,52,53,54,148,283,296$, 319

Bartels, M. 211, 229

Bartley, S., s. Graybiel, A. 25, 58,143

Bartley, S. H., s. Schneider, C. W. 163,190

Baruk, H., s. Claude, H. 361, 365,366

Bass, R. I. 353, 359

Bass, R. L. 357 peiano, $0.478,481,484$

Batini, C., Pompeiano, 0. 478, 484

Bauermeister, M. 85, 89, 94, $136,241,263$

Bauermeister, M., Werner, H., Wapner, S. 85, 136

Von Baumgarten, R. J. 555, $567,579,580$

Von Baumgarten, R. J., Atema, J., Hukuhara, J., Rocker, M. 580

Von Baumgarten, R. J., Baldrighi, G., Atema, J., Shillinger, G. L. 558, 559, 560, 580

Bechinger, D., Kongehl, G., Kornhuber, H.H. 56, 58, 136

Bechinger, D., Kongehl, G., Kornhuber, H. H., Walther, C. 594,615

Bechinger, D., Kriebel, J., Schlager, M. 196, 229

Bechterew, $W$. von 451, 456, $460,463,464,465,466,468$, $471,472,479,484$

Beck, K. 164, 185, 357

Beck, O., Blach, P. 276, 278 615

Becker, W., Deecke, L., Grözinger, B., Kornhuber, H. H. 601

Becker, W., Fuchs, A. F. 591, 596,615

Becker, W., Hoehne, O., Iwase, K., Kornhuber, H. H. 600 , 615

Becker, W., Jürgens, R. 595, 615

Becker, W., Klein, H. M. 199, 229

Beckwith, F. D., s. Kennedy, R. S. 345,352

Beerens, A. J. J. 423, 444

Begbie, G. H. 357

Behr, K., Preber, L., Silfverskiold, D. F. 444

Von Behrman, W. 304, 315

Beischer, D. E., s. Graybiel, A. 575

Beischer, D. E., s. Meek, J. C. 427, 448

Von Békésy, G. 24, 25, 33, 34, $44,68,74,75,106,153,362$, $366,416,427,429,432,444$
Becker, W. 588, 592, 594, 596,
Belanger, F., Mayne, R. 29, 137,573

Belanger, F., s. Mayne, R. 517, $521,522,530,577$

Beller, H. K., s. Morant, R. B. 169,189

Bender, M. B., Jung, R. 162, 186

Bender, M. B., Shanzer, S. 216, 217, 229, 590, 615

Bender, M. B., Weinstein, E. A. 214,229

Bender, M. B., s. Cohen, B. 586, 616

Bender, M. B., s. Pasik, P. 217, 232

Benfari, R. C. 119, 137

Benjamins, C. E., Huizinga, E. 165,186

Benson, A. J. $6,14,39,42,44$, $45,72,111,115,123,127$, $13 \%, 294,295,296,297,299$, $300,301,310,311,312,313$, $314,316,378,383,550,573$

Benson, A. J., Barnes, G. R. 111, 112, 137, 290, 311, 312, 316

Benson, A. J., Bodin, M. 111, $112,115,118,123,137,182$, $186,234,256,263,288,292$, $293,294,295,309,310,311$, $316,546,550,573$

Benson, A. J., Brand, J. L. 36, 137, 365, 366

Benson, A. J., Diaz, E., Farrugia, P. 75, 111, 113, 137

Benson, A. J., Goorney, A. B., Reason, J. T. 36, 137, 365, 366

Benson, A. J., Guedry, F. E. $45,53,54,113,128,137$

Benson, A. J., Guedry, F. E., Melvill Jones, G. 111, 112, $116,137,287,288,290,316$, $548,549,552,553,566,567$, 574

Benson, A. J., Sternfeld 312

Benson, A. J., Whiteside, T. C. D. $262,263,299,300,316$, 550,573

Benson, A. J., s. Guedry, F. E. 128,144

Benson, A. J., s. Reason, J. T. 36,150

Bergmann, F., Gutman, J. 364, 366 
Bergstedt, M. 131, 137, 256,|Blohmke, A., s. Sattler, C. H. 263, 291, 300, 303, 304, 307, $316,351,561,574$

Bergstedt, M., s. Aschan, G. 62, $136,200,229,307,315,419$, 443

Bergstedt, M., s. Fregly, A. R. 347,351

Beritov, I. S. $8,90,137,156$, $186,501,574$

Berkeley 571

Berman, A. J., s. Taub, E. 134, 152

Berry, C. 393, 398, 402, 403

Berry, C. A., Homick, G. L. 402,402

Berry, C. A., s. Graybiel, A. 103, 104, 143, 242, 244, 264

Berry, N., s. Mann, C. W. 88, 147

Berthelow-Berry, N. H., s. Mann, C. W. 84, 86, 88, 147

Bertini, M. 160, 186

Best, C. H., Taylor, N. B. 400, 403

Bethe, A. 466,484

Bickford, R. G., s. Mahoney, J. L. $362,367,374,386$

Bielschowsky, A., s. Hofmann, F. B. 160,188

Billingham, H. T. 554, 556, 574

Billingham, J. 298, 316, 573

Billingham, J., s. Graybiel, A. $103,104,143,242,244,264$

Birren, J. E. 95, 137, 353, 357

Birren, J. E., s. Fisher, M. B. 355,358

Bischof, N. 157, 158, 159, 160, $163,165,166,177,178,186$, 414,444

Bischoff, N., Scheerer, E. 117, $137,159,160,161,169,170$, $174,176,177,178,180,182$, $184,185,186$

Bittermann, M. E., Worchel, P. 162,186

Bizzi, E. 586, 612, 615

Blach, P., s. Beck, O. 276, 278

Blackburn, L. H., s. Cohen, M. M. 107,140

Blackman, N., s. Angyal, A. 365,366

Blair, S. M., s. Westheimer, G. 587, 599, 620

Blakmore, C., s. Carpenter, R. H. S. 162,186 211,232

Bodin, M. A. 295, 296, 310, 312, 316

Bodin, M., s. Benson, A. J. 111, $112,115,118,123,137,182$, $186,234,256,263,288,292$, 293, 294, 295, 309, 310, 311, $316,546,550,573$

Bokhov, B. B., s. Arlaschenko, N. I. 353

Bordogna, A., s. Girotti, G. 164, 187

Boring, E. G. $160,186,566,574$

Borison, H. L., Wang, S. C. 399,403

Bornhardt, A. 463, 465, 468, 484

Bornschein, V. H., Schubert, G. 120,137

Bornstein, M. B., s. Babkin, B. P. 400,402

Borry, W., s. Jones, G. M. 429, 447

Bos, J. H. 437, 444

Bos, J. H., Jongkees, L. B. W., Philipszoon, A. J. 316

Bos, J. H., Philipszoon, A. J. $410,410,437,444$

Bourdon, B. 79, 86, 88, 137

Bowsher, D., s. Walberg, F. $268,274,280$

Brady, J. F., s. Newsom, B. D. 354,359

Braemer, W. 156, 178, 180, 181, 186

Braitenberg, V. 604, 615

Braitenberg, V., Atwood, R. P. 604,615

Braitenberg, V., Onesto, N. 604,616

Brand, J. J. 365,366

Brand, J. L., s. Benson, A. J. $36,137,365,366$

Brandt, Th., Dichgans, J. 118, 119,138

Brandt, Th., Dichgans, J,. Koenig, E. 118, 119, 138

Brandt, Th., Wist, E., Dichgans, J. 119, 125, 138

Brandt, Th., s. Dichgans, J. $116,117,118,119,125,141$, 401,403

Brandt, U. 426, 444

Brandt, U., Fluur, E. 102, 138, $159,416,444$
Braun, G. I., s. Hellebrandt, F. A. 360

Bray, P. F., Ziter, F. A., Lahey, M. E., Myers, G. G. 213, 229

Brecher, G. A., Schubert, G. 160,186

Breuer, 7, 17, 68, 235

Breuer, J. 276, 278, 414, 416, 425,444

Brindley, B. G. S. 604, 616

Van den Brink, G., s. Miller, E. F. $86,94,149,241,264$

Brodal, A. 126, 138, 574, 589

Brodal, A., Pompeiano, O., Walberg, F. 268, 278, 565, 574

Brodal, A., s. Pompeiano, 0. 268, 280

Brodal, A., s. Walberg, F. 268, 274,280

Bromiley, R. B., s. Bard, P. 607,615

Brown, J. H. 41, 42, 43, 46, 59, $138,373,383,574$

Brown, J. H., Crampton, G. H. $61,62,131,138,377,380$, 383

Brown, J. H., Marshall, J. E. 370,383

Brown, J. H., Wolfe, J. W. 60 , 138

Brown, J. H., s. Marshall, J. E. $131,148,365,367,376,377$, 381,387

Brown, J. L. 91, 92, 138, 235, 249,263

Brown, K. R., s. York, E. 359

Brown, L. 182, 186

Brown, M. B., s. Ritvo, E. R. 365,368

Brown, R. H., Guedry, F. E. $379,380,383$

Brown, R. H., Imus, H., Niven, J. I., Graybiel, A. 23, 138

Brown, R. H., s. Graybiel, A. $75,82,107,143,508,542$, 575

Brucher, J. M. 611, 612, 616

Bruck, A. 357

Brun, E., Knudson, E., Raaschov, F. 393, 403

Brunia, C. H. M., Hoppenbrouwers, T. 271,278

Brunner, H. 428, 444

Bruns, O. 406, 410, 444

Brunswik, E. 156, 177, 180, 186 
Brunswik, E., Kardos, L. 157, Carpenter, R. H. S., Blakmore, 186

Bryanov, I. I., s. Yuganov, E. M. 554, 556, 580

Buddenbrock, W. von 465, 484

Bühler, K. 156, 157, 186

Bürgi, S. 353

Burke, U. L., s. Maxwell, S. S. $371,372,373,387$

Burtt, N. E. 85, 138

Buser, P., Imbert, M. 600, 616

Van Buskirk, W. C. 579

Busygin, V. Ye., s. Arlaschenko, N. I. 353

Buxton, C. E., s. Seashore, R. H. 356

Buys, E. $62,138,415,418,420$, 444

Buys, E., Dohlman 426

Byford, G. H. 22, 23, 35, 117, $138,380,383$

Byford, G., s. Hallpike, C. S. $25,145,429,446$

Cairns, H., s. Hallpike, C. S. 576

Cajal 217

Caldwell, G. M., s. Alden, F. D. 357

Callahan, F. E. 358

Camarda, V., s. Caporale, R. 376,383

Camis, M. 283, 316, 470, 471, 484,485

Candland, D. K., s. Vernon, J. A. 35.9

Canella, C. J., s. Mann, C. W. 35,147

Cannon, W. B. 574

Cannon, W. B., Haimovici, H. 459,460

Cannon, W. B., Rosenblueth, A. 459,460

Cantrell, R. P. 357

Caporale, R., Camarda, V. 376, 383

Cappel, K. 58, 138, 508, 574

Capps, M. J., Collins, W. E. $370,371,373,383$

Carlstrom, D. 16, 138

Carmichael, E. A., Dix, M. R., Hallpike, C. S. 222, 229

Carpenter, M. B. 616

Carpenter, M. B., Fabrega, H., Glinsmann, W. 479, 485

Carpenter, M. S. 358

Carpenter, R. H. S. 589, 616
C. 162,186

Cawthorne, T., Dix, M., Hallpike, C., Hood, J. 43, 52, $138,506,574$

Cawthorne, T. E., Fitzgerald, G., Hallpike, C. S. 451, 454, $460,472,483,485$

Cawthorne, T., Hallpike, C. S. 437,444

Cenacchi, V., Fenu, G., Gabrielli, L. 364, 366

Ceran, S. J., s. Guedry, F. E. $43,45,46,50,58,59,144$, 506,575

Chambers, W. W., Sprague, J. M. 478,485

Chambers, W. W., s. Liu, C. N. 459,461

Chambers, W. W., s. Sprague, J. M. 478, 48.9

Chandler, K. A., s. Werner, H. $94,154,163,190,241,266$

Chinn, H., Smith, P. 389, 403

Chow, K. L. Riesen, A. H., Newell, F. W. 211, 229

Christian, P. 25, 138

Chusid, .J. G., Gutiérry-Mahoney, G. G. de 482,485

Chutorian, A. M., s. Solomon, G. E. 213,232

Cipriani, A. 391, 403

Citron, C., Hallpike, C. S. 437, 444

Clark, B. 23, 25, 72, 82, 86, 138 , 139

Clark, B., Graybiel, A. 56, 72, $86,90,94,96,107,108,110$, $139,164,175,186,247,249$, $263,325,351,353,399,401$, $403,542,57$.

Clark, B., Graybiel, A., MacCorquodale, K. 25, 13.9

Clark, B., Stewart, J. D. 23, 25, $26,27,28,30,35,42,55,58$, $59,63,117,139,380,383$

Clark, B., s. Graybiel, A. 22, 82, $86,93,95,131,143,162$, $179,187,247,263,392,403$, $567,5 \% 5$

Clark, G., Lashley, K.S.612,616

Clark, L. B. 465,485

Clark, Wilbur, C. 573

Clarke, M., s. Precht, W. 452, 461

Clarkson, F., s. McFarland, J. H. 175,188
Claude, H., Baruk, H., Aubry, M. $361,365,366$

Clegg, W. C., Dunfield, N. M. $72,85,139$

Clynes, M. 571, 574

Coats, A. C., Smith, S. Y. 304, 305,316

Cobb, S., s. Schaltenbrand, G. 476,489

Coermann, R. R. 359

Cohen, B. 229

Cohen, B., Henn, V. 217, 229, 590,616

Cohen, B., Highstein, S. M. 115, 126,139

Cohen, B., Suzuki, J., Bender, I. B. 586,616

Cohen, B., Takemori, S. 116, 126,140

Cohen, B., Takemori, S., Uemura, T. $119,125,140$

Cohen, B., s. Aschoff, J. C. 587, $597,598,615$

Cohen, B., s. Goto, K. 362, 367

Cohen, B., s. Uemura, T. 203, $205,221,232,475,489$

Cohen, L. A. 206, 229, 584, 616

Cohen, M. M., Crosbie, R. J., Blackburn, L. H. 107, 140

Colbert, E. G., Koegler, R. R., Markham, C. H. 365, 366

Colehour, J. K. 401

Colehour, J. K., Graybiel, A. 400,403

Colehour, J. K., s. Graybiel, A. $134,143,338,342,352,567$, 575

Colenbrander, A. 100, 140, 159, $186,241,263$

Collard, M., s. Thiébaut, F. 356

Collewijn, H. 588, 599, 616

Collewijn, H., Van der Mark, F. 587,616

Collins, V. D., Howe, E. C. 353 , 355

Collins, W. E. $36,44,46,66,67$, $115,118,124,132,134,140$, $316,363,364,365,366,370$, $371,372,373,374,375,376$, $378,379,380,381,382,383$, $384,425,444,574$

Collins, W. E., Crampton, G. H., Posner, J. B. 362, 366

Collins, W. E., Guedry, F. E. $53,54,59,60,62,135,140$, $363,366,381,384,423,444$ 
Collins, W. E., Guedry, F. E., Posner, J. B. 363, 366, 375, 384

Collins, W. E., Mertens, R. A. $378,380,384$

Collins, W. E., Poe, R. H. 365, 366

Collins, W. E., Posner, J. B. 362,366

Collins, W. E., Schroeder, D. J., Gilson, R. D., Guedry, F. E. 130,140

Collins, W. E., Schroeder, D. J., Hill, R. J. 130, 140

Collins, W. E., Schroeder, D. J., Mertens, R. A. 376, 381, 384

Collins, W.E., Schroeder, D. J., Rice, N., Mertens, R. A., Kranz, G. 547, 574

Collins, W. E., Updegraff, B. P. $370,373,384$

Collins, W. E., s. Capps, M. J. $370,371,373,383$

Collins, W. E., s. Gilson, R. D. 130,142

Collins, W. E., s. Guedry, F. E. $60,61,62,65,118,131,132$, $135,144,145,363,365,367$, $374,377,378,379,381,386$

Collins, W. E., s. Mertens, R. A. $370,371,372,373,387$

Collins, W. E., s. Schroeder, D. J. 130, 151

Coltheart, M. 162, 186

Conrad, B., s. Aschoff, J. C. 199, 208, 210, 229, 587, 606, 615

Conraux, C., s. Greiner, G. F. 223,230

Conraux, C., s. Thiébaut, F. 356

Corlett, B. M. A., s. Money, K. E. $285,288,308,319$

Correia, M. J. 85, 140, 574

Correia, M. J., Guedry, F. E. $75,111,113,115,140,182$, 186, 290, 292, 309, 310, 311, $316,365,367,392,403,546$, 574

Correia, M. J., Hixson, W. C., Niven, J. I. 98, 99, 100, 101, $103,140,164,165,186$

Correia, M. J., Money, K. E. $112,140,312,316,551,574$

Correia, M. J., s. Hixson, W. C. $10,12,13,15,120,146$

Correia, M. J., s. McLeod, M. E. 304,319
Correia, M. J., s. Niven, J. I. 75, $77,106,111,150,308,310$, $311,319,391,404,506,561$, 578,579

Corso, J. I. 36, 140

Corvera, J., Hallpike, C. S., Schuster, E. H. J. 17, 140

Cotzin, M., s. Alexander, S. J. 262,263

Cowey, A., s. Latto, R. 612, 618

Cramer, D. B., s. Fregly, A. R. 322,351

Cramer, D. B., s. Graybial, A. $259,261,262,264,333,352$

Cramer, R. L. 33, 140, 517, 574

Cramer, R. L., s. Dowd, P. J. 377,384

Cramer, R. L., s. Guedry, F. E. $61,63,64,145$

Cramer, R. L., s. Mathog, R. H. 577

Crampton, G. H. 286, 287, 300 , $316,364,367,370,371,373$, $384,400,403,482,485,508$, $550,552,565,574,575$

Crampton, G. H., Gall, K. 60, 140,575

Crampton, G. H., Schwam, W. J. $362,367,373,384$

Crampton, G. H., Young, F. A. 119,140

Crampton, G. H., s. Brown, J. H. $61,62,131,138,377,380$, 383

Crampton, G. H., s. Collins, W. E. 362,366

Crickmar, S. D., s. Ross, H. E. 91,151

Critchley, M. 8, 141

Crosbie, R. J., s. Cohen, M. M. 107,140

Crosbie, R. J., s. Gray, R. F. 299,317

Crosby, E. C., Humphrey, T., Lauer, E. W. 7, 8, 141

Crosby, E. C., s. Henderson, J. W. 612,617

Culbert, S. S. 169, 186

Cullen, J. F., Harper, C. R. 104, 141

Cunningham, D. R. 358

Cunningham, D. R., Goetzinger, C. P. 358

Cummings, M., s. Guedry, F. E. $60,63,64,145$

Cureton, T. K. 358
Curran, C. R., Lane, H. L. 181, 187

Cyon, E. 463, 465, 485

Dain, C. A. 358

Dallenbach, K. M., s. Worchel, P. 354

Dallos, P. J., Jones, R. W. 589, 616

Dal Ri, H., Schaefer, K. P. 479, 481,485

Dandy, W. E. $353,439,444$

Dauterive, H. J., s. Mann, C. W. 84, 86, 88, 147

Davey, P. R. 358

Davies, J. D., s. Dearnaley, E. J. 378,384

Day, M. A. C. 359

Day, R., Wade, N. 72, 141, 174, 187

Day, R. H., s. Wade, N. J. 72, 153

Deane, F. R., s. Graybiel, A. 342,352

Dearnaley, E. J., Reason, J. T., Davies, J. D. 378, 384

Decher, H. 223, 229

Deecke, L., Scheid, P., Kornhuber, H. H. 600, 616

Deecke, L., s. Becker, W. 601

Deecke, L., s. Kornhuber, H. H. $600,601,618$

De Haan, P. 357

Deitlein, L. F., s. Graybiel, A. $103,104,143,242,244,264$

De Lage 7, 408

Delage, Y., s. Aubert, H. 408, $410,418,419,433,443$

Demanez, J. P., s. Ledoux, A. 222,231

Dèmetriades, T. D., s. Spiegel, E. A. $451,456,462,475,489$

Denny-Brown, D. 610, 611, 612,616

Deriu, P. L., s. Azzena, G. B. 475,484

Derwort, A. 162, 187

Diaz, E., s. Benson, A. J. 75, $111,113,137$

Diaz, E., s. Reason, J. T. 120, $125,132,150$

Dichgans, J. 118

Dichgans, J., Brandt, Th. 116, $117,118,119,125,141,401$, 403

Dichgans, J., Held, R., Young, L., Brandt, Th. 119, 125, 141

40 Hb. Sensory Physiology, Vol. VI/2 
Dichgans, J., Jung, R. 117, 141

Dichgans, J., Körner, F., Voigt, K. 117,141

Dichgans, J., Kornhuber, H. H. 208, 211, 229

Dichgans, J., s. Brandt, Th. $118,119,125,138$

Dichgans, J., s. Körner, F. 117, 146

Dichgans, J., s. Schmidt, C. L. 607, 620

Di Giorgio, A. M. 476, 485

Di Giorgio, A. M., Manni, E. 475,485

Von Diringshofen, H. 119, 153

Von Diringshofen, H., Kessel, G., Osypka, P. 25, 153

Van Dishoeck, H. A. E., Spoor, A., Nijhoff, P. 8, 22, 35, $117,153,380,384,416,444$, 579

Dittler, R. 417, 444

Divorkin, S., s. Babkin, B. P. 400, 402

Dix, M. R., Hallpike, C. S. 206, $230,437,444$

Dix, M. R., Hood, J. D. 375, $376,377,384$

Dix, M. R., s. Carmichael, E. A. 222,229

Dix, M., s. Cawthorne, T. 43, $52,138,506,574$

Dobie, T. B. 42,141

Dockeray, F. C., Isaacs, S. 353

Dockstader, S. L. 30, 141

Dodge, R. 25, 58, 141, 361, 367, $374,382,384,418,434,444$

Dodge, R., s. Travis, R. C. 44, $77,78,152$

Dohlman, G. 220, 230, 451, 460, $513,514,561,573,575$

Dohlman, s. Buys, E. 426

Dolley, W. L. 465, 485

Dolowitz, D. A. 420, 425, 445

Dolowitz, D. A., Forssman, B., Henriksson, N. G. 269, 278

Dolowitz, D. A., s. Forssman, B. $374,378,380,385$

Dolowitz, D. A., s. Henriksson, N. G. $226,230,269,279$

Domagk, G. F., Zippel, H. P. 482,485

Donaldson, J. M. L., s. AlbeFessard, D. 609, 615

Donoso, M., s. HernándezPéon, R. 67, 145

Doty, R. I. 28, 30, 141, 582
Douglas, W. K. 358

Douglas, W. K., s. Minners, H. A. 358

Douglass, C. G., s. Green, R. E. 353

Dow, R. S. 485

Dowd, P. J. 364, 365, 367

Dowd, P. J., Cramer, R. L. 377, 384

Drake, C. G., Stavraky, G. W. 459,460

Draper, C. S., Wrigley, W., Hovorka, J. 496, 575

Dreyfuss, R. 469, 485

Duensing, F., Schaefer, K. P. $69,141,287,317,452,453$, $454,460,464,469,485,586$, 590,616

Duensing, F., Schaefer, K. P., Trevisan, C. 484,486

Duffy, F. H., Lombrose, C. T. 130,141

Dumont, S. 287, 317

Duncker, K. 178, 179, 187

Dunfield, N. M., s. Clegg, W. C. $72,85,139$

Dunlap, K. 371, 373, 384

Dusek, E. R. 357,358

Dzendolet, E. 359, 555, 556, 575

Eberhart, H. D., Inman, V. T. 359

Eccles, J. C., Ito, M., Szentágothai, J. 604, 616

Eckel, W. 285, 317, 452, 454, $460,464,486$

Ectors, L., s. Kennard, M. A. $611,612,617$

Edholm, O. G., s. Barcroft, H. 393,402

Edwards, A. S. 355

Van Egmond, A. A. J., Groen, J. J., Hulk, J., Jongkees, L. B. W. $425,430,445$

Van Egmond, A. A. J., Groen, J. J., Jongkees, L. B. W. 19, $20,25,28,29,30,33,34,44$, $60,121,153,285,317,415$, $420,423,425,428,430,432$, $445,455,462,472,483,486$, $502,506,507,579$

Van Egmond, A. A. J., Jongkees, L. B. W., Groen, J. J. 428,445

Egyed, J., s. Spiegel, E. A. 8, 152
Eijsvogel, M. H., s. Quix, F. H. 182,189

Einstein 103, 104

Ek, J., Jongkees, L. B. W., Klijn, J. 23, 30, 58, 141, $423,425,432,445$

Ek, J., s. Klijn, J. A. J. 427, 447

Ekvall, L., s. Grant, G. 205, 230

Elftman, H. 359

Elsner, W. 42, 141

Emel'ianov, M. D., s. Galle, R. R. 126,142

Engen, T., Ross, B. M. 40, 141

Engström, H., Lindeman, $\mathrm{H}$. H., Ades, H. W. 70, 142

Engström, H., Wersäll, J. 69, 141

Erikson, J. H., s. Lachman, J. 365,367

Eriksson, A. W., s. Vliet, A. G. M. van 211,232

Eriksson, L., s. Fluur, E. 200, 230

Escher, F. 472, 486

Eviatar, A., s. Ritvo, E. R. 365, 368

Ewald 430

Ewald, J. R. 291, 317, 451, 452, $460,463,464,465,466,467$, $468,471,472,482,486$

Van Eyck, M. 451, 462

Fabrega, H., s. Carpenter, M. B. 479,485

Farber, Yu. V., s. Arlaschenko, N. I. 353

Farmer, T. W., Mustian, V. M. 353

Farrugia, P., s. Benson, A. J. $75,111,113,137$

Fearing, F. S. $355,361,367$, $373,384,421,445$

Fearing, F. S., Mowrer, O. H. $361,367,373,384$

Fearing, F., s. Halstead, W. 373,386

Feilchenfeld, H. 93, 142

Feldmann, H. 445

Fender, D. H., s. St.-Cyr, G. J. 589,620

Fenu, G., s. Cenacchi, V. 364, 366

Feoktistov, Yugatov 556

Fernández, C. 205, 230

Fernández, C., Fredrickson, J. M. $115,126,142$ 
Fernández, C., Goldberg, J. M. $19,39,142,507,509,510$, $512,515,527,552,575$

Fernández, C., Goldberg, J. M., Abend, W. K. 532, 575

Fernández, C., Lindsay, J. R. $408,410,445$

Fernández, C., Schmidt, R. 370,385

Fernández, C., s. Fredrickson, J. M. 221, 230

Fernández, C., s. Goldberg, J. M. $60,62,143,452,461$, $509,510,512,515,524,575$

Fernández, C., s. Henriksson, N. G. $370,371,373,386$

Fernández, C., s. Proctor, L. R. $370,373,387$

Fernández C. s. Reding, G. R. 261,265

Ferreri, G. 414, 445

Figge, U., s. Fredrickson, J. 8, 142

Finer, B. L., s. Aschan, G. 365, 366

Finney, L. M., s. White, W. J. 359

Fischer, J. J. 353

Fischer, M. H. 93, 142, 159, $163,164,179,187,417,418$, $425,435,445,464,465,471$, $472,480,486$

Fischer, M. H., Veits, C. 418, 435,445

Fischer, M. H., Wodak, E. 269, $270,271,272,274,276,278$, $429,433,445$

Fischer, M. H., s. Wodak, E. 270,280

Fisher, M. B., Birren, J. E., Leggett, A. L. 355, 358

Fiske, D. 353

Fitts, P. M., s. Jones, R. E. 85, 146

Fitzgerald, G., Hallpike, C. S. 222,230

Fitzgerald, G., s. Cawthorne, T. E. $451,454,460,472$, 483,485

Fleishman, E. A. 72, 85, 142, 358

Floberg, I. E., Hamburger, C. A., Hydén, H. 482, 486

Flock, A., Wersäll, J. 519, 575

Flourens, J. P. M. 291, 307, $317,405,410,445,463,465$, 486

$40^{*}$
Fluur, E. 17, 102, 142, 451, 452, $454,460,486$

Fluur, E., Eriksson, L. 200, 230

Fluur, E., Mellström, A. 69, $102,142,163,165,187,235$, 263

Fluur, E., Mendel, L. 374, 378, 385

Fluur, E., s. Brandt, U. 102, $138,159,416,444$

Foerster, O. 609, 616

Ford, F. R., Walsh, F. B. 353

Forsius, H., s. Vliet, A. G. M. 211,232

Forssman, B. 376, 378, 380, $385,426,445$

Forssman, B., Henriksson, N. G., Dolowitz, D. A. 374, $378,380,385$

Forssman, B., s. Dolowitz, D. A. 269,278

Forssman, B., s. Henriksson, N. G. $226,230,269,279$

Fowler, E. P., Jr., s. Glorig, A. 353

Franks, W. R., s. Johnson, W. H. $390,391,392,403,558$, 576

Franseen, E. B., s. Hellebrandt, F. A. 276, 279, 360

Franzen, R., s. McFarland, R. A. 356

Fredrickson, J. M., Fernández, C. 221,230

Fredrickson, J., Figge, U., Scheid, P., Kornhuber, H. H. 8, 142

Fredrickson, Kornhuber, Schwarz 159

Fredrickson, J. M., Schwarz, D., $72,142,287,317$

Fredrickson, J. M., Schwarz, D. Kornhuber, H. H. 230, 287, $317,584,609,616$

Fredrickson, J. M., s. Fernández, C. 115, 126, 142

Freedman, S. J. 134, 142

Fregly, A. R., Bergstedt, M., Graybiel, A. 347, 351

Fregly, A. R., Graybiel, A. 250, $263,321,322,323,324,328$, $330,333,336,345,346,350$, 351

Fregly, A. R., Graybiel, A., Smith, M. J. 322, 333, 338, 351
Fregly, A. R., Kennedy, R. S. 344,351

Fregly, A. R., Oberman, A., Graybiel, A., Mitchell, R. E. 324,351

Fregly, A. R., Smith, M. J., Graybiel, A. 322, 338, 351

Fregly, A. R., Smith, M. J., Wood, C. D., Cramer, D. B. 322,351

Fregly, A. R., s. Graybiel, A. $134,143,234,235,261,262$, $263,264,321,322,323,324$, $333,338,342,350,351,352$, 567,575

Fregly, A. R., s. Igarashi, M. 321,352

Fregly, A. R., s. McClure, J. A. 399,404

Fregly, A. R., s. Miller, E. F. $86,93,94,95,96,149,241$, $264,325,352$

French, R. S., s. Newsom, B.D. 354

Frenzel, H. 198, 200, 204, 221, $230,438,439,445,454,460$, $482,483,486$

Freud 570, 614

Friedberg, J., s. Money, K. E. $399,400,404,407,411,448$

Fries, E. C., s. Hellebrandt, F. A. 360

Frisina, R. 358

Fuchs, A. F. 589, 616

Fuchs, A. F., Kornhuber, H. H. $586,598,599,616$

Fuchs, A. F., Luschei, E. S. $586,590,617$

Fuchs, A. F., s. Becker, W. 591, 596,615

Fuchs, A. F., s. Robinson, D.A. $592,612,619$

Fujimoto, T., s. Tokita, T. 355

Fujita, Y., Rosenberg, J., Segundo, J. P. 452, 460

Fukuda, T. 270, 273, 278, 354, 584,617

Fukuda, T., Hinoki, M., Tokita, T. $373,378,385$

Fukuda, T., Tokita, T. 353, 354, 357

Fukuda, T., Tokita, T., Aokia, S., Watanabe, T., Hishida, K., Tashiro, K., Miyata, H., Mazuoka, U. 376, 377, 385

Furukawa, R., s. Honjo, S. 357 
Gabrielli, L., s. Cenacchi, V. 364,366

Gaeffke, H. 592, 593, 617

Galambos, R., s. Rupert, A. 452,461

Galebsky, A. 6, 142

Gall, K., s. Crampton, G. H. 60, 140,575

Galle, R. R., Emel'ianov, M. D. 126,142

Galle, R. R., Yemel'yanov, M. D. 359

Garcin, R., s. Rademaker, G.G. J. 277, 280, 584, 619

Garner, W. R. 57, 142

Garner, W. R., Hake, H. W. 56, 57,142

Garten, S. 88, 90, 142, 164, 187

Gastaut, H. 215, 230

Gazenko, 0. 254, 263

Gear, R. J., s. Grieve, D. W. 360

Geissler, H. G. 175, 187

Gelb, A. 162, 187

Geldard, F. A. 7, 142

Gernandt, B. E. 72, 142, 268, $279,284,285,286,287,317$, $426,445,452,454,460,586$, 617

Gernandt, B., Igarashi, E. M., Ades, H. W. 434, 445

Gernandt, B. E., Thulin, C. A. $268,279,452,454,460,464$, 486

Gernandt, B., s. Andersson, S. 7,136

Gescheider, G. A., Wright, J. H. 85, 142

Ghent, L., s. Semmes, J. 8, 151

Gibson, J. J. 156, 162, 166, 168, $173,178,181,187$

Gibson, J. J., Mowrer, O. H. $109,119,142,160,162,187$

Gibson, J. J., Radner, M. 160, $162,169,187$

Gierke 527

Gierke, H. E. von, s. Harris, C. S. 358

Gierke, H. E. von, s. Nixon, C. W. 359

Gilbreth, D. A. 575

Gildenberg, P. L., Hassler, R. 475,486

Gillingham, K. K. 365, 367

Gillingham, K., s. McCabe, B. F. 426,448
Gilson, R. D., Guedry, F. E., Gorshikov, A. L., s. Yuganov, Stockwell, C. W. 131, 142

Gilson, R. D., Schroeder, D. J., Collins, W. E., Guedry, F.E. 130,142

Gilson, R. D., Stockwell, C. W., Guedry, F. E. 56, 62, 142

Gilson, R. D., s. Collins, W. E. 130,140

Gilson, R. D., s. Guedry, F. E. $45,53,56,108,145$

Gilson, R. D., s. Schroeder, D. J. 130,151

Gilson, R. D., s. Stockwell, C. W. 65,152

Giretti, M. L. 476, 478, 486

Giretti, M. L., s. Azzena, G. B. 475,484

Giretti, M. L., s. Manni, E. 475, 488

Girotti, G. 164, 187

Girotti, G., Bordogna, A. 164, 187

Glinsmann, W., s. Carpenter, M. B. 479,485

Glorig, A., Fowler, E. P., Jr. 353

Goble, G. J., s. Newsom, B. D. 354,359

Goetzinger, C. P. 358

Goetzinger, C. P., s. Cunningham, D. R. 358

Goetzinger, C. P., s. Scanlon, S. L. 359

Goldberg, J. M., Fernández, C. $60,62,143,452,461,509$, $510,512,515,524,575$

Goldberg, J. M., s. Fernández, C. $19,39,1+2,507,509,510$, $512,515,527,532,552,575$

Goldberg, L. 276, 279, 355, 359

Goldberg, L., s. Aschan, G. M. 307,315

Goldberg, M. E., s. Wuri\%, R. H. $217,232,604,620$

Goldfien, A., s. York, E. 359

Goltz, F. 463, 464, 465, 466, 479,486

Gonshor, A. 134, 604, 617

Gonshor, A., Melvill Jones, G. 131,143

Gonshor, A., s. Melvill Jones, G. 131,148

Goodson, J. E., s. Miller, J. W. $119,120,149$

Goorny, A. B., s. Benson, A. J. $36,137,365,366$
E. M. 554, 556, 580

Goto, K. 357

Goto, K., Tokumasu, K., Cohen, B. 362,367

Goto, T., s. Tokita, T. 355

Grahe 79

Grahe, K. 434, 445

Grant, G., Aschan, G., Ekvall, L. 205,230

Grant, W. T. 355

Gray, R. F., Crosbie, R. J. 299, 317

Graybiel, A. 75, 143, 165, 234, $244,256,263,324,325,330$, $350,351,390,392,401,403$, $426,429,445,573$

Graybiel, A., Brown, R. H. 75, $82,107,143,508,542,575$

Graybiel, A., Clark, B. 82, 86, $93,95,143,162,179,187$, $247,263,325,351$

Graybiel, A., Clark, B., MacCorquodale, K., Hupp, D. 22,143

Graybiel, A., Clark, B., Zarriello, J. J. 131, 143, 353, $392,403,567,575$

Graybiel, A., Fregly, A. R. 234, $263,321,322,323,350,351$

Graybiel, A., Guedry, F. E., Johnson, W. H., Kennedy, R. $378,380,381,385$

Graybiel, A., Hupp, D. I. 22, $23,143,380,385$

Graybiel, A., Johnson, W. H. $143,262,263,309,317,325$, 351,550

Graybiel, A., Kellogg, R. S. $103,143,254,263,555,575$

Graybiel, A., Kennedy, R. S., Knoblock, E. C., Guedry, F. E., Mertz, W., McLeod, M. E., Colehour, J. K., Miller, F. F., Fregly, A. R. $134,143,338,352,567,575$

Graybiel, A., Kerr, W., Hupp, D., Bartley, S. 25, 58, 143

Graybiel, A., Meek, J. C., Beischer, D. E., Riopelle, A. J. 575

Graybiel, A., Miller, E. F. 75, $143,234,257,262,263,264$

Graybiel, A., Miller, E. F., Billingham, J., Waite, R., Berry, C. A., Deitlein, L. F. 103, 104, 143, 242, 244, 264 
Graybiel, A., Miller, E. F., Newsom, B., Kennedy, R. $91,96,143,164,187,237$, $247,256,264$

Graybiel, A., Niven, J. I., MacCorquodale, K. 299, $317,416,434,445$

Graybiel, A., Patterson, J. L. $81,85,143,247,252,264$

Graybiel, A., Schuknecht, H. F., Fregly, A. R., Miller, E. F. II., McLeod, M. E. $235,264,324,333,352$

Graybiel, A., Smith, C. R., Guedry, F. E., Jr., Miller, E. F. II., Fregly, A. R., Cramer, D. B. 261, 262, 264, 333,352

Graybiel, A., Stockwell, C. W., Guedry, F. E., Jr. 234, 262, 264

Graybiel, A., Thompson, A. B., Deane, F. R., Fregly, A. R., Colehour, J. K., Ricks, E. L. 342,352

Graybiel, A., Whiteside, W. H. 575

Graybiel, A., Wood, C. D. 402, 403

Graybiel, A., Wood, C. D., Miller, E. F. II., Cramer, D. B. 257,264

Graybiel, A., s. Brown, R. H. 23,138

Graybiel, A., s. Clark, B. 25, 56, $72,86,90,94,96,107,108$, $110,139,164,175,186,247$, $249,263,325,351,353,399$, $401,403,542,574$

Graybiel, A., s. Colehour, J. K. 400,403

Graybiel, A., s. Fregly, A. R. $250,263,321,322,323,324$, $328,330,333,336,338,345$, $346,347,350,351$

Graybiel, A., s. Guedry, F. E. 131, 132, 144, 145, 344, 352, $373,377,378,381,382,386$, 567,576

Graybiel, A., s. Harris, C. S. 365,367

Graybiel, A., s. Johnson, W. H. $399,403,500,576$

Graybiel, A., s. Kellogg, R. S. 304, 318

Graybiel, A., s. Kennedy, R. S. $345,352,354$
Graybiel, A., s. Lansberg, M.P. $256,264,300,302,318,550$, 577

Graybiel, A., s. McClure, J. A. 399,404

Graybiel, A., s. McMitchael, A. E. 578

Graybiel, A., s. Meek, J. C. 427, $44 S$

Graybiel, A., s. Miller, E. F. 86, $93,94,95,96,100,103,149$, $159,164,165,175,179,189$, $234,235,239,240,241,242$, $251,252,257,259,262,264$, $265,325,330,352,525,526$, 578

Graybiel, A., s. Minners, H. A. 358

Graybiel, A., s. Niven, J. I. 262, $265,354,472,483,488$

Graybiel, A., s. Reason, J. T. $110,120,123,131,133,151$

Graybiel, A., s. Roman, A. J. 298, 320

Graybiel, A., s. Whiteside, T.D. M. $35,154,256,266$

Graybiel, A., s. Woellner, R. C. $159,190,239,266,525,580$

Green, R. E., Douglass, C. C. 353

Greenberg, G. 178, 187

Greene, D., s. Smith, K. U. 360

Greiner, G. F., Conraux, C., Picart, P. 223, 230

Griesbach, E., s. Holst, E. von 163,188

Grieve, D. W., Gear, R. J. 360

Griffith, C. R. $361,367,371$, $375,376,378,381,385,581$, 617

Grigoryev, Yu. G., s. Arlaschenko, N. I. 353

Grimes, R. H., s. White, W. J. 359

Grippo, J., s. Precht, W. 458, 461

Groebbels, F. 465, 486

Groen, J. J. 6, 60, 62, 65, 67, $120,143,144,294,296,317$, 408, 410, 416, 419, 424, 425, $426,429,430,445,446$

Groen, J. J., Jongkees, L. B. W. $25,28,29,31,34,44,45,46$, $144,362,367,378,385,421$, $446,506,575$
Groen, J. J., Lowenstein, O., Vendrick, A. J. H. 19, 59, $62,144,283,317,415,423$, $446,502,508,509,510,511$, $512,518,575$

Groen, J. J., s. Van Egmond, A. A. J. 19, 20, 25, 28, 29, $30,33,34,44,60,121,153$, $285,317,415,420,423,425$, $428,430,432,445,455,462$, $472,483,486,502,506,507$, 579

Groen, J. J., s. Jongkees, L. B. W. $71,73,77,78,79,80,87$, $146,417,418,419,436,447$, 516,576

Grözinger, B., s. Becker, W. 601

Gualtierotti, T., Alltucker, D. S. $452,461,464,486$

Guedry, F. E. $9,23,48,56,60$, $61,66,74,75,77,87,92$, $106,111,112,113,114,115$, $116,119,120,123,124,125$, $126,127,130,131,132,133$, $134,144,182,187,234,264$, $290,294,295,309,310,317$, $325,352,365,367,373,375$, $376,377,378,379,380,381$, $382,385,386,392,403,446$, 541, 546, 576

Guedry, F. E., Ambler, R. K. $116,126,129,130,131,144$

Guedry, F. E., Benson, A. J. 128,144

Guedry, F. E., Ceran, S. J. 43, $45,46,50,58,59,144,506$, 575

Guedry, F. E., Collins, W. E. $60,61,62,65,135,144,381$, 386

Guedry, F. E., Collins, W. E., Graybiel, A. 131, 132, 145. $377378,381,386$

Guedry, F. E., Collins, W. E., Sheffey, P. L. 118, 145, 363, $365,367,374,378,379,381$, 386

Guedry, F. E., Cramer, R. L., Koella, W. P. 61, 63, 64, 145 Guedry, F. E., Graybiel, A. $131,132,144,373,377,378$, $382,386,567,576$

Guedry, F. E., Graybiel, A., Collins, W. E. $377,378,381$, 386 
Guedry, F. E., Harris, C. S. 74, $77,87,105,106,107,145$, $308,317,541,576$

Guedry, F. E., Holmes, J. T. 130,145

Guedry, F. E., Jr., Kennedy, R. S., Harris, C. S., Graybiel, A. 344, 352

Guedry, F. E., Lauver, L. S. 44, $58,59,60,145,363,367,381$, 386

Guedry, F. E., Montague, E. K. $120,123,124,145,378,380$, $386,527,554,576$

Guedry, F. E., Owens, G. G., Cummings, M., Norman, J. W. $60,63,64,145$

Guedry, F. E., Owens, G. G., Norman, J. W. 44, 49, 58, 145

Guedry, F. E., Richmond, G. $27,28,145$

Guedry, F. E., Stockwell, C. W., Gilson, R. D. 45, 53, 56, 108, 145

Guedry, F. E., Stockwell, C. W., Norman, J. W., Owens, G. G. $44,47,48,51,52,56,108$, 145

Guedry, F. E., s. Ambler, R. K. 126,136

Guedry, F. E., s. Benson, A. J. $45,53,54,111,112,113$, $116,128,137,290,292,309$, $310,311,316,548,549,552$, $553,566,567,574$

Guedry, F. E., s. Brown, R. H. $379,380,383$

Guedry, F. E., s. Collins, W. E. $53,54,59,60,62,130,135$, $140,363,366,375,381,384$, 423,444

Guedry, F. E., s. Correia, M. J. $75,111,113,115,140,182$, $186,365,367,392,403,546$, 574

Guedry, F. E., s. Gilson, R. D. $56,62,130,131,142$

Guedry, F. E., s. Graybiel, A. 134, 143, 234, 261, 262, 264, $333,338,352,378,380,381$, $385,567,575$

Guedry, F. E., s. Harris, C. S. 365,367

Guedry, F. E., Jr., s. Lansberg, M. P. 256, 264, 300, 302, $318,550,577$
Guedry, F. E., s. Mann, C. W. $22,117,148$

Guedry, F. E., s. Passey, G. E. $72,85,150$

Guedry, F. E., s. Schroeder, D. J. 130, 151

Guedry, F. E., s. Stockwell, C. W. $65,108,109,110,152$, $256,265,311,320$

Günther, W. 195, 230

Güttich, A. 270, 274, 279, 437, 446,486

Guignard, J. C. 360

Guillemen, V., s. Torok, N. 220, 232

Gulick, W. I., s. Vernon, J. A. 359

Gurfinkel, V. S., s. Babskii, E. B. 359

Gurnee, H. 77, 78, 145

Gutierry-Mahoney, G. G. de, s. Chusid, J. G. 482, 485

Gutman, J., s. Bergmann, F. 364,366

Guttich, A. 361, 367

Haber, R. N. 134, 145

Hagbarth, K. E., s. Aschan, G. 365,366

Haimovici, H., s. Cannon, W. B. 459,460

Hakas, P., Kornhuber, H. H. 222,230

Hake, H. W., s. Garner, W. R. $56,57,142$

Hallgren, B. 35.3

Hallpike, C. S. 291,317

Hallpike, C. S., Cairns, H. 5\%6

Hallpike, C. S., Hood, J. D. 35, $43,52,63,64,145,425,429$, 446

Hallpike, C. S., Hood, J., Byford, G. $25,145,429,446$

Hallpike, C. S., s. Carmichael, E. A. 222,229

Hallpike, C., s. Cawthorne, T. $43,52,138,437,444,451$, $454,460,472,483,485,506$, 574

Hallpike, C. S., s. Citron, C. 437,444

Hallpike, C. S., s. Corvera, J. 17,140

Hallpike, C. S., s. Dix, M. R. $206,230,437,444$

Hallpike, C. S., s. Fitzgerald, G. $222,2.30$
Halpern, L. 162, 187

Halstead, W. 373, 382, 386

Halstead, W., Yacorzynski, G., Fearing, F. 373, 386

Hamburger, C. A., Hydén, $H$. 482,486

Hamburger, C. A., s. Floberg, I. E. 482,486

Hamersma, H. 222, 230, 425, 434,446

Hammer, L. R. 103, 145

Hampson, J., Harrison, C., Woolsey, C. 598, 617

Hancock, J. A. 353

Harden Jones, F. R. 559, 560, 576

Harlan, W. L., s. Mahoney, J. L. $362,367,374,386$

Harper, C. R., s. Cullen, J. F. 104, 141

Harris, C. S., von Gierke, H. E. 358

Harris, C. S., Guedry, F. E, Graybiel, A. 365, 367

Harris, C. S., Sommer, H. S. 358

Harris, C. S., s. Guedry, F. E. $74,77,87,105,106,107$, $145,308,317,344,352,541$, 576

Harris, C. S., s. Nixon, C. W. 359

Harris, J., s. Morant, R. B. 162, 189

Harrison, C., s. Hampson, J. 598,617

Hasegawa, T. 165,188

Hassler, R. 217, 230

Hassler, R., s. Gildenberg, P.L. 475,486

Hauty, G. T., s. Pearson, R. G. $72,85,150$

Havill, C. D., s. Sadoff, M. 25, 37,151

Hawkins, W. R., s. Minners, H. A. 358

Haygood, Robert C., s. Lindholm, Ernest 573

Head, H. 353, 358

Heath, S. R. 358

Hebb, D. O. 36, 145

Hécaen, H., Ajuriaguerra, J. de 218,230

Hein, A., s. Held, R. 134, 145

Held, R. 134, 135, 145

Held, R., Hein, A. 134, 145 
Held, R., s. Dichgans, J. 119, 125,141

Hellebrandt, F. A., Braun, G.I. 360

Hellebrandt, F. A., Franseen, E. B. $276,279,360$

Hellebrandt, F. A., Riddle, K. S., Larsen, E. M., Fries, E. C. 360

Helmholtz 157

Hemingway, A. 389, 399, 403

Henderson, J. W. 371, 386

Henderson, J. W., Crosby, E. C. 612,617

Henkes, H. E., s. Hulk, J. 446

Henmon, V. A. C. 353

Henn, V., s. Cohen, B. 217, 229, 590,616

Hennebert, P. E. 272, 276, 279, 420,446

Henriksson, N. G. 220, 226, 230

Henriksson, N. G., Dolowitz, D. A., Forssman, B. 226, 230, 269, 279

Henriksson, N. G., Forssman, B., Dolowitz, D. A. 269, 279

Henriksson, N. G., Johansson, G., Olsson, L. G., Östlund, H. 276, 279, 360

Henriksson, N. G., Kohut, R., Fernández, C. 370, 371, 373, 386

Henriksson, N. G., Lundgren, A., Tibbling, L., Nilsson, A., Anderson, A. 36, 145

Henriksson, N. G., s. Dolowitz, D. A. 269,278

Henriksson, N. G., s. Forssman, B. $374,378,380,385$

Henriksson, N. G., s. Nilsson, A. 36,150

Hering 157

Hernández-Péon, R., Donoso, M. 67,145

Hershey, Daniel, Ed. 562, 576

Hertzberg, O. E. 358

Hertzman, M., s. Witkin, H. A. 181,190

Heschl 438

Hess, W. R. 612, 617

Hicks, S. A. 358

Highstein, S. M., s. Cohen, B. $115,126,139$

Hilding, A. C. 25,146

Hill, C. J., Jr., s. Alexander, S. J. 262, 263
Hill, R. J., s. Collins, W. E. 130, 140

Hill, R. M., s. Horn, G. 130, 146

Hiltz, F. F. 566,576

Hinchcliffe, R. 380, 386, 434, 446

Hinoki, M. 354

Hinoki, M., Kitahara, M. 360

Hinoki, M., Kurosawa, R. 437, 446

Hinoki, M., s. Fukuda, T. 373, 378,385

Hinsdale, C. 356

Hirsch, C. 272, 273, 279, 354

Hishida, K., s. Fukuda, T. 376, 377,385

Hitzig 369

Hixson, W. C. 39, 146

Hixson, W. C., Niven, J. I. 66, $128,146,502,507,576$

Hixson, W. C., Niven, J. I., Correia, M. J. 10, 12, 13, 15 120,146

Hixson, W. C., s. Correia, M. J. 98, 99, 100,101, 103, 140, $164,165,186$

Hixson, W. C., s. Niven, J. I. $66,75,77,106,111,150$, $308,310,311,319,391,404$, $506,561,578,579$

Hoehne, O., s. Becker, W. 600, 615

Hofman, F. B. 182,188

Hofmann, F. B., Bielschowsky, A. 160,188

Holmes, J. T., s. Guedry, F. E. 130,145

Holsopple, J. Q. 376, 386

Von Holst, E. $68,98,153,178$, $180,181,185,188,464,466$, $473,486,581,582,612,617$

Holst, E. von, Griesbach, E. 163,188

Holst, E. von, Mittelstaedt, H. $156,158,169,188,416,426$, $446,584,617$

Homick, G. L., s. Berry, C. A. 402, 402

Honjo, S., Furukawa, R. 357

Hood, J. D. 419, 446

Hood, J. D., Pfaltz, C. R. 362, $367,373,386$

Hood, J., s. Cawthorne, T. 43, $52,138,506,574$

Hood, J. D., s. Dix, M. R. 375, $376,377,384$
Hood, J. D., s. Hallpike, C. S. $25,35,43,52,63,64,145$, 429,446

Hoppenbrouwers, T., s. Brunia, C. H. M. 271, 278

Horcholle-Bossavit, Tyć-Dumont 586

Horn, G., Hill, R. M. 130, 146

Horton, M. O., s. Alden, F. D. 357

House, W. F. 333, 352

Hovorka, J., s. Draper, C. S. 496, 575

Howard, I. P., Templeton, W. B. $7,17,72,82,86,94,95$, $117,119,120,146,160,165$, 178,188

Howe, E. C., s. Collins, V. D. 353,355

Howland, Howard, C. 573

Hubbard, A. W., Stetson, R.H. 360

Hubel, D. H., Wiesel, T. N. 172,188

Huddleston, O. L. 371, 373, 386

Hudspath, W. J. 482, 487

Huizinga, E. 165, 188, 465, 487

Huizinga, E., s. Benjamins, C. E. 165,186

Hukuhara, J., s. Von Baum. garten, R. J. 580

Hulk, J., Henkes, H. E. 446

Hulk, J., Jongkees, L. B. W. $29,146,406,410,420,430$, 432,446

Hulk, J., s. Van Egmond, A. A. J. $425,430,445$

Hulk, J., s. Jongkees, L. B. W. $430,431,447$

Humphrey, T., s. Crosby, E. C. $7,8,141$

Hunter, J., s. Taylor, N. B. J. 401, 404

Hupp, D., s. Graybiel, A. 22. $23,25,58,143,380,385$

Husband, R. W. 356

Hyden, Holger, Ed. 566, 567, 576

Hydén, H., s. Floberg, I. E. 482,486

Hydén, H., s. Hamburger, C. A. 482,486

Ibid 577

Igarashi, E. M., s. Gernandt, B. 434,445 
Igarashi, M. 17, 146, 283, 317, Johnson, W. H., Stubbs, R. A., $507,510,516,576$

Igarashi, M., Fregly, A. R., Tokita, T. 321, 352

Imamura, H., s. Takebayshi, H. 354

Imbert, M., s. Buser, P. 600, 616

Imus, H., s. Brown, R. H. 23, 138

Inman, V. T., s. Eberhart, H. D. 359

Ireland, P. E., s. Nito, Y. 319

Irwin, J. A. 405, 410, 427, 446

Isaacs, S., s. Dockeray, F. C. 353

Isch, F., s. Thiébaut, F. 356

Ismail, A. H., s. Bárány, J. W. 359

Ito, M. 604,617

Ito, M., Nisimaru, N., Yamamoto, M. 586, 617

Ito, M., Yoshida, M. 587, 617

Ito, M., Yoshida, M., Obata, K. $587,605,617$

Ito, M., s. Eccles, J. C. 604, 616

Iwase, K., s. Becker, W. 600, 615

Jackson, M. M., Sears, C. W. 298,317

James, s. Nagel 7

James, W. 90, 146, 405, 410, 446

Janeke, J. B. 294, 308, 310, 315,317

Janeke, J. B., Oosterveld, W. J. 302,317

Janeke, M. 551, 576

Jansen, J., s. Nyby, O. 602, 619

Jatho, K. 223, 230, 439, 446

Johansson, G., s. Henriksson, N. G. 276, 279, 360

Johner, C. H., Perlman, H. B. $353,365,367$

Johnson, D. D., Torok, N. 375, 386

Johnson, W. H. 392, 400, 403, 568

Johnson, W., Jongkees, L. B. W. 427

Johnson, W. H., Mayne, J. W. $403,607,617$

Johnson, W. H., Meek, J. C., Graybiel, A. 399, 403, 500, 576
Kelk, G. F.. Franks, W. R. $390,391,392,403,558,576$

Johnson, W. H., Taylor, N. B. J. 390,403

Johnson, W. H., s. Ackerman, U. 399, 402

Johnson, W. H , s. Graybiel, A. $143,262,263,309,317,325$, $351,378,380,381,385,550$

Johnson, W. H., s. Money, K. E. $285,288,308,319$

Johnson, W. H., s. Nito, Y. 319 Johnson, W. H., s. Sunahara, F. A. $393,404,408,411,449$

Johnson, W. H., s. Taylor, N. B. J. 401, 404

Johnson, W. H., s. Taylor, W. J. R. 393, 397, 404

Johnston, J. B. 582, 617

Jones, E. G. 611

Jones, E. G., Powell, T. P. S. $600,610,617$

Jones, G. M. 415, 447

Jones, G. M., Borry, W., Kowalsky, W. 429,447

Jones, G. M., Spells, K. E. 585, 617

Jones, G. M., s. Michael, J. 589, 61.9

Jones, I. H. 353

Jones, R. E., Milton, J. L. Fitts, P. M. 85,146

Jones, R. W., s. Dallos, P. J. 589,616

De Jong, J. M. B. V. 206, 230, $436,437,447$

De Jong, R. N. 353

Jongkees, L. B. WV. 17, 146, $163,164,165,188,226,230$, $291,299,304,305,306,318$, $353,413,414,434,436,447$

Jongkees, L. B. W., Groen, J.J. $71,73,77,78,79,80,87$, $146,417,418,419,436,447$

Jongkees, L. B. W., Hulk, J. $430,431,447$

Jongkees, L. B. W., Klijn, J. A. J. 447

Jongkees, L. B. W., Philipszoon, A. J. 234, 258, 264, $308,318,364,367,447$

Jongkees, L. B. W., s. Bos, J. H. 316
Jongkees, L. B. W., s. Van Egmond, A. A. J. 19, 20, 25, $28,29,30,33,34,44,60$, $121,153,285,317,415,420$, $423,425,428,430,432,445$, $455,462,472,483,486,502$, $506,507,579$

Jongkees, L. B. W., s. Ek, J. $23,30,58,141,423,425$, 432,445

Jongkees, I. B. W., s. Groen, J. J. 25, 28, 29, 31, 34, 44, $45,46,144,362,367,378$, $385,421,446,506,516,575$, 576

Jongkees, L. B. W., s. Hulk, J. $29,146,406,410,420,430$, 432,446

Jongkees, L. B. W., s. Johnson, W. 427

Jonsson, R., Steen, B. 360

Jordan, P. 273, 274, 279, 354

Joseph, J. 360

Jürgens, R., s. Becker, W. 595, 615

Jung, R. 220, 230, 482, 487

Jung, R., Kornhuber, H. H. $212,216,231,482,483,484$, $487,587,589,617$

Jung, R., s. Bender, M. B. 162, 186

Jung, R., s. Dichgans, J. 117, 141

Kado, R. T., s. Adey, W. R. 261,263

Kahn, A., s. Torok, N. 271, 280

Kamath, R., s. Pfaltz, C. R. 451,461

Kamei, T., Kornhuber, H. H. $200,201,204,231$

Karbowski, K. 408, 410, 447

Kardos, L. 157, 188

Kardos, L., s. Brunswik, E. 157,186

Kasyian, I. I., s. Yuganov, E. M. 554, 556, 580

Kate, J. H. 508, 576

Kato, N., s. Saito, I. 310,320

Keidel, Plattig 596, 603, 606

Kelk, G. F., s. Johnson, W. H. $390,391,392,403,558,576$

Keller, E. L., Robinson, D. A. 586,617

Kellogg, R. S. 103, 146, 159, $18 S, 525,526,528,530,531$, 554,576 
Kellogg, R. S., Graybiel, A. | Kleyn, A. de 437, 468, 487, 586, Kopanev, V. I., s. Yuganov, E. 304,318 618

Kellogg, R. S., s. Graybiel, A. Kleyn, A. de, Magnus, R. 284, $103,143,254,263,555,575$

Kellogg, R. S., s. Miller, E. F. $103,149,239,240,252,257$, 262,265

Kelly, C. F., s. Winget, C. M. 373,388

Kemp, J. M., Powell, T. P. S. 602,617

Kempinsky, W. H. 8, 146

Kennard, M. A. 612, 617

Kennard, M. A., Ectors, L. 611, 612,617

Kennedy, R. S. 67, 110, 146

Kennedy, R. S., Graybiel, A. 354

Kennedy, R. S., Graybiel, A., McDonough, R. C., Beckwith, F. D. 345, 352

Kennedy, R. S., s. Fregly, A.R. 344,351

Kennedy, R., s. Graybiel, A. $91,96,134,143,164,187$, $237,247,256,264,338,352$, $378,380,381,385,567,575$

Kennedy, R. S., s. Guedry, F. E. 344,352

Kerr, W., s. Graybiel, A. 25, 58, 143

Keser, H. 223, 225, 231

Kessel, G., s. Von Diringshofen, H. 25, 153

Khilov, K. L. 292, 318

Kimble, G. A., Perlmuter, L.C. $5,135,146$

Kimura, K., s. Owada, K. 320

King 291

King, B. G. 371, 386

Kinsbourne, M. 130, 146

Kiørboe, F. 291, 318

Kirstein, R. 220, 231

Kishi, M., s. Takebayshi, H. 354

Kislyakov, V. A., Orlov, I. V. 318

Kitahara, M. 277, 279, 360

Kitahara, M., Sato, T. 357

Kitahara, M., Uno, R. 110, 146, 414,447

Kitahara, M., s. Hinoki, M. 360

Klein, H. M., s. Becker, W. 199, 22.9

Kleinknecht, F. 85, 146

Kleint, H. 160, 163, 178, 179, 180,188 318

Kleyn, A. de, Versteegh, C. 211 , $231,277,279,307,318,407$, 410,447

De Kleyn, A., s. Magnus, R. $464,465,471,472,488$

Klijn, J. A. J., Ek, J. 427, 447 Klijn, J. A. J., s. Ek, J. 23, 30, $58,141,423,425,432,445$

Klijn, J. A. J., s. Jongkees, L. B. W. 447

Klinke, R., Schmidt, C. I. 119, 146

Klix, F. 163, 180, 188

Klopp, H. W. 167, 188

Knapp, E. 202, 231

Knapp, H. 561, 576

Knoblock, E. C., s. Graybiel, A. $134,143,338,352,567$, 575

Knoblock, E. C., s. Minners, H. A. 358

Knudson, E., s. Brun, E. 393, 403

Koch, G., s. Seashore, H. G. 354

Koegler, R. R., s. Colbert, E. G. 365,366

Köhler, W., Wallach, H. 162, 188

Koella, W. 292, 295, 296, 309, 310,318

Koella, W. P., s. Guedry, F. E. $61,63,64,145$

Koenig, E., s. Brandt, Th. 118, 119,138

Körner, F., Dichgans, J. 117, 146

Körner, F., s. Dichgans, J. 117, 141

Körner, F., s. Schiller, P. H. 604,619

Koffka, K. 168, 188

Kohler, J. 160, 166, 167, 188

Kohut, R., s. Henriksson, N.G. $370,371,373,386$

Kolb, G. 466, 467, 469, 473, $475,476,480,482,487$

Kolosov, I. A., s. Yuganov, E. M. 554, 556, 580

Von Kongehl, G., Kornhuber, H. H. 56, 57, 153

Kongehl, G., s. Bechinger, D. $56,58,136,594,615$
M. 554, 556, 580

Kornhuber, H. H. 126, 146 , $197,198,203,205,206,207$, $209,210,211,212,213,214$, $216,218,219,220,225,226$, $231,439,447,464,471,482$, $487,566,573,576,583,584$, $585,587,588,589,590,596$, $598,599,602,603,604,605$, $606,607,608,611,613,614$, 618

Kornhuber, H. H., Aschoff, J. C. $600,602,610,618$

Kornhuber, H. H., Deecke, L. $600,601,618$

Kornhuber, H. H., Krejcova, Schmidt 591

Kornhuber, H. H., Waldecker, G. 195,231

Kornhuber, H. H., s. Aschoff, J. C. 199, 208, 210, 229, 587, 606,615

Kornhuber, H. H., s. Bader, W. $222,229,587,615$

Kornhuber, H. H., s. Bechinger, D. $56,58,136,594,615$

Kornhuber, H. H., s. Becker, W. $600,601,615$

Kornhuber, H. H., s. Deecke, L. 600,616

Kornhuber, H. H., s. Dichgans, J. 208, 211, 229

Kornhuber, H. H., s. Fredrickson, J. 8, 142, 159, 230, $287,317,584,609,616$

Kornhuber, H. H., s. Fuchs, A. F. $586,598,599,616$

Kornhuber, H. H., s. Hakas, P. 222,230

Kornhuber, H. H., s. Jung, R. $212,216,231,482,483,484$, $487,587,589,617$

Kornhuber, H. H., s. Kamei, T. 200, 201, 204, 231

Kornhuber, H. H., s. Von Kongehl, G. 56, 57, 153

Kornhuber, H. H., s. Lange, G. $204,231,454,461,483,484$, 487

Kottenhoff, H., Lindahl, L. 119,146

Kowalsky, N., s. Melvill Jones, G. $45,52,53,54,148,283$, 296,319

Kowalsky, W., s. Jones, G. M. $429,44 \pi$ 
Kragh, J. 269, 271, 279

Kranz, G., s. Collins, W. E. 547, 574

Kreidl, A. 95, 147, 358, 405, $410,447,470,487$

Krejcova, s. Kornhuber, H. H. 591

Kriebel, J., s. Bechinger, D. 196,229

Krieger, H. P., s. Pollack, M. 365,368

Krijger, R. 406, 408, 410, 425, 448

Kurashvili, A. Ye., Babiyak, V. P. 303,318

Kurihara, M., s. Takebayshi, H. 354

Kuriyama, T., s. Takebayshi, H. 354

Kuroda, W., s. Tokita, T. 355

Kurosawa, R., s. Hinoki, M. 437,446

Kuypers, H. G. J. M., Lawrence, D. G. 612,618

Kuypers, H. G. J. M., s. Pandya, D. N. 600, 610, 612, 619

Van der Laarse, W. D., s. Oosterveld, W. J. 298, 302, 304, 306, 319

Lachman, J., Aarons, L., Erikson, J. H. 365, 367

Lahey, M. E., s. Bray, P. F. $213,22.9$

Lane, H. L., s. Curran, C. R. 181,187

Lange, B. 477, 478, 487

Lange, G., Kornhuber, H. H. $204,231,454,461,483,484$, 487

Langelaan, J. W. 426, 448

Langova, J. 356

Lansberg, M. P. 77, 78, 106, $120,126,147$

Lansberg, M. P., Guedry, F. E., Jr., Graybiel, A. 256, 264, $300,302,318,550,577$

Larsen, E. M., s. Hellebrandt, F. A. 360

Lashley, K. S., s. Clark, G. 612, 616

Latto, R., Cowey, A. 612, 618

Lauer, E. W., s. Crosby E. C. $7,8,141$

Laurell, L., s. Aschan, G. M. 307,315
Laurens, H., Miles, A. 472, 487 $\mid$ Löwenberg, D. 477, 487

Lauver, L. S., s. Guedry, F. E. $44,58,59,60,145,363,367$, 381,386

Lawrence, D. G., s. Kuypers, H. G. J. M. 612,618

Lebeden, V. I., s. Yuganov, E. M. $554,556,580$

Ledoux, A. 60, 62, 69, 147, 283, $284,285,287,318,452,461$

Ledoux, A., Demanez, J. P. 222,231

Le3, F. S. $463,487,560,577$

Leggenhager, K. 400, 403

Leggett, A. L., s. Fisher, M. B. 355,358

Lehman, P., s. McEachern, D. $391,399,400,401,404$

Leiri, E. 413, 448

Leonard, J. A. 358

Letko, W., Stone, R. W. 554, 577

Letko, W., s. Stone, R. W. 112 , $113,152,544,545,546,579$

Levin, P. M. $354,482,487$

Lewis, H. B., s. Witkin, H. A. 181,190

Licklider, J. C. R. 36, 147

Lidvall, H. F. $362,363,367$, $374,378,380,381,386,406$, $410,411,448$

Lilly, J. C. 609,618

Lindahl, L., s. Kottenhoff, $\mathrm{H}$. 119,146

Lindeman, H. H. 69, 147, 290, 318

Lindeman, H. H., s. Eng. ström, H. 70, 142

Lindholm, Frnest, Haygood, Robert, C. 573

Lindsay, J. R., s. Fernández, C. $408,410,445$

Lindsley, D. B., Schreiner, I. H., Magoun, H. W. 478, 487

Linschoten, J. 178, 188

Liu, C. N., Chambers, W. W. 459,461

Liu, C. N., s. MeCouch, G. P. 459,461

Liu, C. Y., s. McCouch, G. P. 459,461

Llinás, R., Precht, W. 607, 618

Ilinás, R., Wolfe, J. W. 599, 608,618

Llinás, R., s. Precht, W. 452, 461

Loeb, J. 466, 487
Lombrose, C. T., s. Duffy, F.H 130,141

Long, G. M. 109, 110, 147

De Long, M. R. 608, 618

Lorente de Nó, R. 217, 231, $284,309,318,428,448,451$, $461,469,487,590,618$

Lorenz, K. 166, 188

Lowenstein, $0.15,60,147,165$, $188,282,284,285,287,318$, $448,466,472,487,552,553$, 573,577

Lowenstein, O., Roberts, T. D. M. 18, 69, 71, 147, 163, 188, $283,290,319,517,518,519$, $520,522,524,525,526,530$, $531,545,559,577$

Lowenstein, O., Sand, A. 283, $284,319,452,461,464,487$, 586,618

Lowensteir, O., Thornhill, R. A. 496,577

Lowenstein, O., s. Groen, J. J. $19,59,62,144,283,317$, $415,423,446,502,508,509$, $510,511,512,518,575$

Luciani, K. 477, 488

Ludvigh, E., s. Miller, J. W. 130,149

Lüdtke, H. 465, 488

Lumpkin, R. C. 371, 386

Lundgren, A., s. Henriksson, N. G. 36,145

Luschei, E. S., s. Fuchs, A. F. $586,590,617$

Maanen, J. C. D. van 405,406 , $408,409,411,426,4.18$

MacCorquodale, K. 25, 147

MacCorquodale, K., Meehl, P. E. 160,188

MacCorquodale, K., s. Clark, B. 25,139

MacCorquodale, K., s. Graybiel, A. 22, 143, 299, 317, $416,434,445$

Mach, E. 7, 17, 24, 25, 30, 31, $68,74,75,76,77,78,79,95$, $104,147,157,319,414,416$, $429,435,448$

Machover, K., s. Witkin, H. A. 181,190

MacKay, D. M. 156, 189, 197

Maekawa, K., Simpson, J. E. $590,604,618$ 
Magnus, R. 68, 147, 163, 178, $189,437,451,456,461,464$, $468,469,470,471,472,473$, 474, 475, 477, 478, 481, 482, 488,618

Magnus, R., De Kleyn, A. 464, $465,471,472,488$

Magnus, R., Storm van Leeuwen, W. 584, 618

Magnus, R., s. Kleyn, A. de 284,318

Magoun, H. W., s. Lindsley, D. B. 478,487

Mahoney, J. L., Harlan, W. L., Bickford, R. G. 362, 367, 374,386

Maitland, T. G. 400,403

Makoto 516

Malcolm, R., Melvill Jones, G. $42,56,60,62,64,147,296$, $306,319,508,509,510,512$, $515,516,552,577$

Malecki, J. 427, 448

Mann, C. W. 24, 72, 84, 89, 90, $93,94,96,110,147,160$, 189,354

Mann, C. W., Berry, N. 88, 147

Mann, C. W., Berthelow-Berry, N. H., Dauterive, H. J. 84, $86,88,147$

Mann, C. W., Canella, C. J. 35, $14 \pi$

Mann, C. W., Dauterive, H. J. $84,88,147$

Mann, C. W., Guedry, F. E., Ray, J. T. 22, 117, 148

Mann, C. W., Passey, G. E. 72, $85,88,147$

Mann, C. W., Passey, G. E., Ambler, R. K. 85, 148

Mann, C. W., Ray, J. T. 25, 26, $27,72,85,147$

Mann, L. 354

Manni, E., Giretti, M. L. 475, 488

Manni, E., s. Di Giorgio, A. M. 475,485

Manning, G. 391, 404

Manning, G. W., Stewart, W. G. 390,404

Manning, K. R., s. Bárány, J. W. 359

Mano, N., s. Baker, R. G. 458, 460

Marant, R. B., s. Wapner, S. 23,153
Marchiafava, P. L., Pompeiano, McClure, C. L. 496, 578

O. 130,148

Van der Mark, F., s. Collewijn, H. 587, 616

Markaryan, S. S. 292, 302, 319

Markham, C. H., Precht, W., Shimazu, H. 459, 461

Markham, C. H., s. Colbert, E. G. 365,366

Markham, C. H., s. Precht, W. $452,453,454,455,456,457$, $458,459,461,465,475,479$, 488

Markham, C. H., s. Ritvo, E.R. 365,368

Marr, D. 604, 619

Marshall, J. E., Brown, J. H. $131,148,365,367,376,377$, 381,387

Marshall, J. E., s. Brown, J. H. 370,383

Martinez, A., s. RiescoMacClure, J. S. 221, 232

Mason, A., s. Ritvo, E. R. 365, 368

Matheson, F. A., s. Sadoff, M. $25,37,151$

Mathog, R. H., Cramer, R. L. 577

Maurer, W., s. Meyer zum Gottesberge, A. 472, 483, 488

Maxwell, S. S. 165, 189, 291, 319

Maxwell, S. S., Burke, U. L., Reston, C. 371, 372, 373, 387

Mayne, J. W., s. Johnston, W. H. $403,607,617$

Mayne, R. 5, 6, 20, 22, 38, 148 , $281,319,495,501,502,507$, $528,529,530,533,554,555$, $560,566,568,577,585,619$ Mayne, R., Belanger, F. 517, $521,522,530,577$

Mayne, R., Mead, R. 566, 577

Mayne, R., s. Belanger, F. 29, 137,573

Mazuoka, U., s. Fukuda, T. $376,377,385$

McCabe, B. F. 308, 319, 376, 387,448

McCabe, B. F., Gillingham, K. 426,448

McCabe, B. F., Ryu, J. H. 475, $479,483,488$

McCabe, B. F., Ryu, I. H., Sekitani, T. $453,459,461$
McClure, J. A. 399, 404

McClure, J. A., Fregly, A. R., Molina, E., Graybiel, A. 399, 404

McCollom, I. N., s. Seashore, R. H. 356

McCouch, G. P., Austin, G. M., Liu, C. N., Liu, C. Y. 459, 461

McDermid, C. D., s. Smith, K. U. 360

McDonough, R. C., s. Kennedy, R. S. 345,352

McEachern, D., Morton, G., Lehman, P. 391, 399, 400, 401, 404

McFarland, J. H., Clarkson, F. 175,188

McFarland, J. H., Wapner, S., Werner, H. 89, 148

McFarland, R. A., Franzen, R. 356

McGill, T. E., s. Vernon, J. A. 359

McIntyre, A. K. 586, 619

McLeod, M. E., Correia, M. J. 304, 319

McLeod, M. E., Meek, J. C. 324, 352

McLeod, M. E., s. Graybiel, A. $134,143,235,264,324,333$, $338,352,567,575$

McMitchael, A. E., Graybiel, A. 578

McNally, W. H., Stuart, G. 389, 404

McNally, W. J. 68, 148, 165, 189

McNally, W. J., Stuart, E. A. $7,17,68,115,148$

McNally, W. J., Tait, J. 277, $279,466,488,584,619$

McNally, W. J., s. Tait, J. 543, 579

McNally, W. S., s. McNaughton, I. P. S. 559, 578

McNaughton, I. P. S., McNally, W. S. 559,578

Mead, R., s. Mayne, R. 566, 577

Meda, E. 120, 148, 381, 387, 392,404

Meehl, P. E., s. MacCorquodale, K. 160, 188

Meek, J. C., Graybiel, A., Beischer, D. E., Riopelle, A. J. 427,448 
Meek, J. C., s. Graybiel, A. 575

Meek, J. C., s. Johnson, W. H. $399,403,500,576$

Meek, J. C., s. McLeod, M. E. 324,352

Meiry, J. L. 25, 27, 28, 30, 68, $71,73,74,75,79,98,148$, $206,223,225,231,283,319$

Meiry, J., s. Young, L. 71, 74, $154,165,190,502,524,525$, $530,539,546,580$

Meissner, P. B., s. Witkin, H. A. 181,190

Mellström, A., s. Fluur, E. 69 , $102,142,163,165,187,235$, 263

Melvill Jones, G. 6, 20, 69, 71, $127,148,285,319,502,527$, $547,553,565,573,578$

Melvill Jones, G., Barry, W., Kowalsky, N. 45, 52, 53, 54, $148,283,296,319$

Melvill Jones, G., Gonshor, A. 131,148

Melvill Jones, G., Milsum, J. H. $19,38,60,148,285,319$, $502,510,578$

Melvill Jones, G., Spells, K. E. $5,38,148,502,508,578$

Melvill Jones, G., s. Benson, A. J. $111,112,116,137,288$, $290,316,548,549,552,553$, $566,567,574$

Melvill Jones, G., s. Gonshor, A. 131,143

Melvill Jones, G., s. Malmcolm, R. $42,56,60,62,64,147$, $296,306,319,508,509,510$, $512,515,516,552,577$

Melvill Jones, G., s. Milsum, J. H. 290,319

Melvill Jones, G., s. Sugie, N. 579

Mendel, L., s. Fluur, E. 374, 378,385

Menzio, P. 476, 488

Mertens, R. A., Collins, W. E. $370,371,372,373,387$

Mertens, R. A., s. Collins, W. E. $376,378,380,381,384,547$, 574

Mertz, W., s. Graybiel, A. 134, $143,338,352,567,575$

Meshman, V. F. 130, 14.9

Mettler, F. A. 608, 611, 619 Netzger, W. 166, 173, 179, 189
Meyer, D. L., s. Schaefer, K. P. $469,473,474,476,478,480$, $481,482,488$

Meyer zum Gottesberge, A., Maurer, W. 472, 483, 488

Meyer zum Gottesberge, A., Plester, D. 165, 189

Michael, J., Jones, G. M. 589, 619

Mickle, W., Ades, H. 7, 8, 149

Miehlke, A. 206, 231

Milbled, G., s. Nayrac, P. 356

Miles, A., s. Laurens, H. 472, 487

Miles, W. R. 276, 279, 356

Miller, E. F. II. 159, 163, 185, $189,234,235,239,240,264$, $324,333,352,525,526,531$, 578

Miller, E. F., Fregly, A. R., Van den Brink, G., Gray. biel, A. 86, 94, 149, 241, 264

Miller, E. F., Fregly, A. R., Graybiel, A. 93, 94, 95, 96, 149, 241, 264, 325, 352

Miller, E. F., Graybiel, A. 86, $93,94,100,149,159,164$, $165,175,179,189,234,235$, 239, 240, 241, 242, 251, 257, $259,262,264,265,324,330$, $333,338,352,525,526,578$

Miller, E. F., Graybiel, A., Kellogg, R. S. 103, 149, 239, 240,265

Miller, E. F. II., Graybiel, A., Kellogg, R. S., O'Donnell, R. D. 252, 257, 262, 265

Miller, E. F. II., Pulec, J. L., Wilcox, J. G., Graybicl, A. 235,265

Miller, E. F., s. Graybiel, A. 75, $91,96,103,104,134,143$, $164,187,234,235,237,242$, $244,247,256,257,259,261$, $262,263,264,567,575$

Miller, G. A. 57, 58, 149

Miller, J. W., Goodson, J. E. $119,120,149$

Miller, J. W., Ludvigh, E. 130, 149

Miller, N. E. 572, 578

Milojevic, B. 200, 231

Milojevic, B., Voots, R. J. 304, 319

Milojevic, B., Watson, J. L. $273,279,354$
Milsum, J. H., Melvill Jones, G. 290,319

Milsum, J. H., s. Melvill Jones, G. $19,38,60,148,285,319$, $502,510,578$

Milton, J. L., s. Jones, R. E. 85, 146

Minners, H. A., Douglas, W. K., Knoblock, E. C., Graybiel, A., Hawkins, W. R. 358

Minners, H. A., White, S. C., Douglas, W. K., Knoblock, E. C., Graybiel, A. 358

Minsky, M. 578

Mishkin, M., s. Teuber, H. L. 8,152

Misovich, M., s. Morant, R. B. 162,189

Mitchell, R. E., s. Fregly, A. R. 324,351

Mittelstaedt, H. 164, 173, 189, 465,488

Mittelstaedt, H., s. Holst, E. von $156,158,169,188,416$, $426,446,584,617$

Mittermaier, R. 428, 433, 434, $448,451,461,464,483,488$

Miyata, H., s. Fukuda, T. 376, 377,385

Mizutani, T., s. Tokita, T. 355

Moffet, R., s. Spiegel, E. A. 8, 152

Molina, E., s. McClure, J. A. 399,404

Molinari, J. A., s. Arslan, M. 8, $136,475,484$

Money, K. E. 310, 319, 389, $391,399,401,404,550,551$, $568,569,573,578$

Money, K. E., Friedberg, J. $399,400,404,407,411,448$

Money, K. E., Johnson, W. H., Corlett, B. M. A. 285, 288, 308,319

Money, K. E., Scott, J. W. 308, $319,543,544,561,578$

Money, K. E., Sokoloff, M., Weaver, R. S. 319

Money, K. E., Wood, J. D. 126, 149

Money, K. E., s. Correia, M. J. $112,140,312,316,551,574$

Money, K. E., s. Nito, Y. 319

Monnier, M., s. Montandon, P. 130,149

Monrad-Krohn, G. H. 354 
Montague, E. K., s. Guediy, Nagel, James 7 F. E. $120,123,124,145$, $378,380,386,527,554,576$

Montandon, A., Russbach, A. $25,149,223,231$

Montandon, P., Monnier, M. 130,149

Montandon, W. 405, 411, 420, 448

Moore, J. W., s. Pezzoli, J. A. 360

Morant, R. B., Aronoff, J. C. 160,189

Morant, R. B., Beller, H. K. 169,189

Morant, R. B., Harris, J. 162, 189

Morant, R. B., Misovich, M. 162,189

Morimoto, M. 319

Morrison, A. R., Pompeiano, O. 130,149

Morsh, J. E. 357

Morsh, J. R. 357

Mortag, H. G., s. Schöne, H. $99,100,105,106,151,163$, 165,190

Morton, D. J. 360

Morton, G., s. McEachern, D. $391,399,400,401,404$

Moruzzi, G., s. Batini, C. 478 , 481,484

Moss, F. S. 357

Mountcastle, V. B., s. Bard, P. 607,615

Mountcastle, V., s. Walzi, E. $7,8,153$

Moushegian, G., s. Rupert, A. 452,461

Mowrer, O. H. 27, 118, 149, 361, $362,367,371,373,375,376$, $387,452,461,464,488$

Mowrer, O. H., s. Fearing, F. S. $361,367,373,384$

Mowrer, O. H., s. Gibson, J. J. $109,119,142,160,162,187$

Müller, G. E. $86,149,160,161$, $175,189,241,265$

Mulder, W. 30, 149, 415, 448

Muskens, L. J. J. 217, 231, 413, 448

Mustian, V. M., s. Farmer, T. W. 353

Myers, G. G., s. Bray, P. F. 213, 229

Mygind, S. H. 68, 149, 269, 279

Myklebust, H. R. 359
Nagel, W. A. 89, 149

Nakayama, S., s. Tokita, T. 355

Nashner, L. M. 251, 265, 360

Nauta 612

Naylor, G. F. 160, 189

Naylor, G. F. K. 189

Nayrac, P., Milbled, G., Parquet, $\mathrm{Ph}$. J. 356

Neal, M. 6, 149

Nelson, J. G. 88, 90, 149

Nelson, J. R. 333, 352

Newell, A. 578

Newell, F. W., s. Chow, K. L. 211,229

Newsom, B. D., Brady, J. F., Goble, G. J. 354, 359

Newsom, B. D., Brady, J. F., Shafer, W. A., French, R. S. 354

Newsom, B., s. Graybiel, A. 91, $96,143,164,187,237,247$, 256, 264

Nieuwenhuysen, J. H. 405, 406, $407,411,426,448$

Nieuwenhys, R. 582, 619

Nijhoff, P., s. Van Dishoeck, H. A. E. 8, 22, 35, 117, 153, $380,384,416,444,579$

Nijhoff, P., s. Roggeveen, L. J. $25,35,151$

Nilsson, A., Henriksson, N. G. 36,150

Nilsson, A., s. Andersson, S. 36, 110,136

Nilsson, A., s. Henriksson, N. G. 36,145

Nisimaru, N., s. Ito, M. 586, 617

Nito, Y., Johnson, W. H., Money, K. E., Ireland, P. E. 319

Niven, J. I., Graybiel, A. 354 , $472,483,488$

Niven, J. I., Hixson, W. C. 66, 150

Niven, J. I., Hixson, W. C., Correia, M. J. 75, 77, 106, $111,150,308,310,311,319$, $391,404,506,561,578,579$

Niven, J. I., Whiteside, T. C. D., Graybiel, A. 262, 265

Niven, J. I., s. Brown, R. H. 23, 138

Niven, J. I., s. Correia, M. J. 98, $99,100,101,103,140,164$, 165,186
Niven, J. I., s. Graybiel, A. 299, $317,416,434,445$

Niven, J. I., s. Hixson, W. C. $10,12,13,15,66,120,128$, $146,502,507,576$

Niven, J. I., s. Whiteside, T. D. M. 35, 154, 256, 266

Nixon, C. W., Harris, C. S., von Gierke, H. E. 359

Noble, R. L. 389, 390, 391, 404

Noble, R. L., Taylor, N. B. J. 393,404

Norman, J. W., s. Guedry, F. E. $44,47,48,49,51,52,56,58$, $60,63,64,108,145$

Northington, P. 482, 488

Northington, P., Barrera, S. E. $471,472,488$

Nyberg, J. W., s. White, W. J. $35 ?$

Nyby, O., Jansen, J. 602, 619

Nylen, C. O. 204, 231

Nylén, C. O., s. Aschan, G. 29, $136,429,430,443$

Nyman, H. 270, 277, 279

Obata, K., s. Ito, M. 587, 605, 617

Oberman, A., s. Fregly, A. R. 324,351

O'Donnell, R. D., s. Miller, E. F. II. 252, 257, 262, 265

Östlund, H., s. Henriksson, N. G. $276,279,360$

Ohm, J. 210, 231

Ohwaki, S. 160,189

Okubu, K., s. Owada, K. 320

Olsson, L. G., s. Henriksson, N. G. $276,279,360$

Oman, C. M., s. Young, L. 42, $56,64,154,296,306,320$, $509,515,516,580$

Omwake, K. T. 357

Onesto, N., s. Braitenberg, V. 604,616

Oosterveld, W. J. 307, 319

Oosterveld, W. J., Van der Laarse, W. D. 298, 302, 304, 306,319

Oosterveld, W. J., s. Janeke, J. B. 302,317

Oppenheimer, E. 179, 189

Orias, O., s. Bard, P. 610, 615

Orlov, I. V., s. Kislyakov, V.A. 318

Orma, E. J. 356 
Ornitz, E. M. 6, 126, 150, 365, |Pendleton, M. E., Paine, R. S. 368

Ornitz, E. M., s. Ritvo, E. R. 365,368

Osterhammel, P., Terkildsen, K., Zilstorff, K. 375, 376, 377,387

Osypka, P., s. Von Diringshofen, H. 25, 153

Outerbridge, J. S. 19, 29, 59, 150

Owada, K., Okubu, K. 320

Owada, K., Shiizu, S., Kimura, K. 320

Owen, E. P., s. Ross, H. E. 91, 151

Owens, G. G., s. Guedry, F. E. $44,47,48,49,51,52,56,58$, $60,63,64,108,145$

Padden, D. A. 90, 150

Paine, R. S., s. Pendleton, M. E. 362,368

Pandya, D. N., Kuypers, H. G. J. M. $600,610,612,619$

Parker, D. E., s. Schöne, H. 99, $100,103,151,163,165,190$

Parker, D. M. 120, 150

Parquet, Ph. J., s. Nayrac, P. 356

Parsons, R. D. 40, 41, 42, 43, $50,56,63,150$

Pasik, P., Pasik, T. 216, 218, 232, 612, 619

Pasik, P., Pasik, T., Bender, M. B. 217,232

Pasik, P., s. Pasik, T. 216, 232

Pasik, T., Pasik, P. 216, 232

Pasik, T., s. Pasik, P. 216, 217, $218,232,612,619$

Passey, G. E. 88, 150, 160, 189

Passey, G. E., Guedry, F. E. $72,85,150$

Passey, G. E., s. Mann, C. W. $72,85,88,147,148$

Patterson, John, D. 573

Patterson, J. L., s. Graybiel, A. $81,85,143,247,252,264$

Pearson, R. G., Hauty, G. T. $72,85,150$

Peiper, A. 123, 150

Peitersen, E. 273, 274, 275, 279, 354,355

Peitersen, E., Zilstorff-Pedersen, K. 272, 274, 275, 276, 280,355

Peitersen, E., s. Zilstorff-Pedersen, K. 273, 274, 280, 355 362,368

Penfield, W. 7, 8, 150, 438, 448

Penman, K. A. 356

Perlman, H. B. 165, 189

Perlman, H. B., s. Johner, C. H. $353,365,367$

Perlmuter, L. C., s. Kimble, G. A. $5,135,146$

Perrin, F. A. C. 359

Peters, G., s. Thauer, R. 466, 467. 473, 480, 489

Peterson, B. W. 452, 461

Peto, A. 6, 126, 150

Pezzoli, J. A., Moore, J. W. 360

Pfaltz, C. R., Arx, S. V. 378, 387

Pfaltz, C. R., Kamath, R. 45l, 461

Pfaltz, C. R., s. Hood, J. F. 362, $367,373,386$

Pfeiffer, Henry, March 573

Philipszoon, A. J. 410, 411, 414, 448

Philipszoon, A. J., s. Bos, J. H. $316,410,410,437,444$

Philipszoon, A. J., s. Jongkees, L. B. W. $234,258,264,308$, $318,364,367,447$

Picart, P., s. Greiner, G. F. 223, 230

Pichler, H. J. 424, 448

Pike, F. H., s. Wilson, T. G. 468,490

Pilz, G. F. 371,387

Plattig, s. Keidel 596, 603, 606

Plester, D., s. Meyer zum Gottesberge, A. 165, 189

Ploog, D. 612, 619

Poe, R. H., s. Collins, W. E. 365,366

Pollack, M., Krieger, H. P. 365, 368

Pollak 7

Pollak, J. 405, 411, 448

Polyakov, B. I., s. Arlaschenko, N. I. 353

Pompeiano, O. 268, 280

Pompeiano, O., Barness, C. D. 585,619

Pompeiano, O., Brodal, A. 268, 280

Pompeiano, O., s. Barness, C. D. 585, 615

Pompeiano, O., s. Batini, C. $478,481,484$
Pompeiano, O., s. Brodal, A. 268, 278, 565, 574

Pompeiano, O., s. Marchiafava, P. L. 130,148

Pompeiano, O., s. Morrison, A. R. 130,149

Popov, A. P. 300, 320

Popov, N. I., s. Yuganov, E.M. $554,556,580$

Portman, G. 561, 579

Portman, M. 579

Posner, J. B., s. Collins, W. E. $362,363,366,375,384$

Poulton, E. C. 40,150

Powell, T. J. 554, 579

Powell, T. P. S., s. Jones, E. G. $600,610,617$

Powell, T. P. S., s. Kemp, J. M. 602,617

Preber, L. 378, 387, 406, 411, 448

Preber, L., s. Behr, K. 444

Precht, W., Grippo, J., Richter, A. 458, 461

Precht, W., Llinás, R., Clarke 452,461

Precht, W., Richter, A., Grippo, A. 458,461

Precht, W., Shimazu, H. 459, 461

Precht, W., Shimazu, H., Markham, C. H. 452, 453, 454, $455,456,457,458,459,461$, $465,475,479,488$

Precht, W., s. Llinás, R. 607, 618

Precht, W., s. Markham, C. H. 459,461

Precht, W., s. Shimazu, H. 60, $151,290,320,452,453,454$, $457,459,462,464,489$

Prescott, J. W. 6, 126, 150

Pribram, K. H. 611, 619

Price, R. H. 36, 150

Proctor, D. F. 400, 404

Proctor, L. R., Fernández, C. $370,373,387$

Pruyser, P. W. 573

Pulec, J. L., s. Miller, E. F. II. 235,265

Purkinje, J. E. 119, 150, 267 $280,291,320,408,411,449$

Quix, F. H. 17, 68, 80, 150, 405, $406,411,435,436,449$

Quix, F. H., Eijsvogel, M. H. 182,189 
Raaschov, F., s. Brun, E. 393, 403

Rademaker, G. G. J. 354, 584, 619

Rademaker, G. G. J., Garcin, R. 277, 280, 584, 619

Rådmark, K. 277, 280

Radner, M., s. Gibson, J. J. $160,162,169,187$

Raikovits, K., s. Szentágothai, J. 475,489

Rashbass, C. 590,619

Ratliff, F., Riggs, L. A. 199, 232

Ratner, S. C. 382,387

Rauch, S. 507, 579

Rawlinson, H. E. 400, 404

Ray, J. T., s. Mann, C. W. 22, $25,26,27,72,85,117,147$, 148

Reason, J. T. 36, 120, 150

Reason, J. T., Benson, A. J. 36, 150

Reason, J. T., Diaz, E. 120, $125,132,150$

Reason, J. T., Graybiel, A. 110, $120,123,131,133,151$

Reason, J. T., s. Benson, A. J. $36,137,365,366$

Reason, J. T., s. Dearnaley, E. J. 378,384

Reding, G. R., Fernández, C. 261, 265

Reston, C., s. Maxwell, S. S. $371,372,373,387$

Reynolds, B. 357

Rhodes, J. M., s. Adey, W. R. 261,263

Ricaldoni, M. A. 357

Ricciuti, E. A., s. Alexander, S. J. 262, 263

Rice, N., s. Collins, W. E. 547, 574

Richmond, G., s. Guedry, F. E. $27,28,145$

Richter, A., s. Precht, W. 458, 461

Ricks, E. L., s. Graybiel, A. 342,352

Riddle, K. S., s. Hellebrandt, F. A. 360

Riesco-MacClure, J. S., Martinez, A. 221, 232

Riesen, A. H. 211, 232

Riesen, A. H., s. Chow, K. L. 211,229
Riggs, L. A., s. Ratliff, F. 199, 232

Riopelle, A. J., s. Graybiel, A. 575

Riopelle, A. J., s. Meek, J. C. 427,448

Ritvo, E. R., Ornitz, E. M., Eviatar, A., Markham, C. H., Brown, M. B., Mason, A. 365,368

Roberts, T. D. M. 18, 95, 151

Roberts, T. D. M., s. Lowenstein, 0. 18, 69, 71, 147, 163, $188,283,290,319,517,518$, $519,520,522,524,525,526$, $530,531,545,559,577$

Robinson, D. A. 586, 587, 588, $589,590,591,592,604,612$, 619

Robinson, D. A., Fuchs, A. F. $592,612,619$

Robinson, D. A., s. Keller, E. L. 586,617

Robinson, D. A., s. Ron, S. 591, 599,619

Robinson, D. A., s. Skavenski, A. A. 589,620

Rocker, M., s. Von Baumgarten, R. J. 580

Roggeveen, L. J., Nijhoff, P. $25,35,151$

Rohrer, F. 58, 151

Roman, A. J., Warren, B. H., Graybiel, A. 298, 320

Romberg, M. H. 276, 280, 354 Romel, E. L., s. Babskii, E. B. 359

Ron, S., Robinson, D. A. 599, 619

Ron, S., Robinson, D. A., Skavenski, A. A. 591, 619

Rosenberg, J., s. Fujita, Y. 452, 460

Rosenblueth, A., s. Cannon, W. B. 459,460

Ross, B. M., s. Engen, T. 40, 141

Ross, D. A. $283,284,320$

Ross, H. E., Crickmar, S. D., Sills, N. V., Owen, E. P. 91, 151

Ross, J. A. 452, 461

Rossum, A. van 408, 411, 429, 432, 449

Rupert, A., Moushegian, G., Galambos, R. 452, 461

Ruppert, J. 361, 368, 369, 387 Schilder, P. 6, 151
Rushmer, R. F. 397, 404

Russbach, A., s. Montandon, A. $25,149,223,231$

Russel, I. S. R. 481, 482, 488

Russell, P. E. 573

Ruttin, E. 435, 449, 472, 483, 488

Ruuth, E., s. Andersson, S. 36, 110,136

Ryu, I. H., s. McCabe, B. F. $453,459,461,475,479,483$, 488

Sadoff, M., Matheson, F. A., Havill, C. D. 25, 37, 151

Saito, I., Wada, H., Yagura, S., Kato, N. 310, 320

Sala, O. 285, 320, 373, 387

Sand, A., s. Lowenstein, O. 283, $284,319,452,461,464,487$, 586,618

Sandström, J. 205, 207, 232

Sasaki, K. 458, 461

Sato, G., s. Spiegel, E. A. 451, 458,462

Sato, T., s. Kitahara, M. 357

Sattler, C. H., Blohmke, A. 211, 232

Scanlon, S. L., Goetzinger, C.P. 359

Schaefer, K. P. 458, 461

Schaefer, K. P., Meyer, D. L. $469,473,474,476,478,480$, 481, 482, 488

Schaefer, K. P., Wehner, H. 482,488

Schaefer, K. P., s. Dal Ri, H. $479,481,485$

Schaefer, K. P., s. Duensing, F. $69,141,287,317,452,453$, $454,460,464,469,484,485$, $586,590,616$

Schaltenbrand, G., Cobb, S. $476,48.9$

Scheerer, E., s. Bischoff, N. 117, $137,159,160,161,169,170$, $174,176,177,178,180,184$, 185,186

Scheid, P., s. Deecke, L. 600, 616

Scheid, P., s. Fredrickson, J. 8 , 142

Schierbeek, P. 406, 411, 430, 449

Schierbeek, P., s. De Vries, Hl. 25,141 
Schillcr, P. H. 217, 232, 612, 619

Schiller, P. H., Körner, F. 604, 619

Schilpp, P. A. 104, 151

Schlager, M., s. Bechinger, D. 196,229

Schmaltz, G. 222, 232, 419, 434, $449,502,506,579$

Schmidt 79

Schmidt, s. Kornhuber, H. H. 591

Schmidt, C. L., Wist, E. R., Dichgans, J. 607, 620

Schmidt, C. L., s. Klinke, R. 119,146

Schmidt, R., s. Fernández, C. 370,385

Schmidt, R. S. 285, 320, 607, 619

Schmitt, F. O., Worden, F. G. $602,606,607,611,613$

Schneider, C. W., Bartley, S. H. 163,190

Schock, G. J. D. 248, 265

Schoen, L. 69, 151, 452, 461, $464,466,472,489$

Schöne, H. 68, 86, 91, 92, 93, $94,98,99,100,103,109$, $151,159,160,163,164,165$, $182,190,235,241,265,435$, $44.9,465,489$

Schöne, H., Mortag, H. G. 105, 106,151

Schöne, H., Parker, D. E. 99, $100,103,151,165,190$

Schöne, H., Parker, D. E., Mortag, H. G. 99, 100, 151, 163, 165,190

Schöne, H., Udo de Hacs, H. $72,85,100,109,125,151$, $160,163,164,165,175,182$, 190

Schöne, H., s. Udo de Haes, H. $92,109,153,163,175,179$, $182,190,294,320$

Schreiner, L. H., s. Lindsley, D. B. 478,487

Schroeder, D. J. $365,368,378$, 379,387

Schroeder, D. J., Gilson, R. D., Guedry, F. E., Collins, W. E. 130,151

Schroeder, D. J., s. Collins, W. E. $130,140,376,381,384$, 547,574
Schroeder, D. J., s. Gilson, R. D. $130,1 \pm 2$

Schubert, G. 120, 151, 408, 411, 449

Schubert, G., s. Bornschein, V. H. 120,137

Schubert, G., s. Brecher, G. A. 160,186

Schuknecht, H. F. 291, 320

Schuknecht, H. F., s. Graybiel, A. $235,264,324,333,352$

Schuster, E. H. J., s. Corvera, J. 17,140

Schwab, R. S. 401, 404

Schwam, W. J., s. Crampton, G. H. $362,367,373,384$

Schwartz, R. P., Vaeth, W. 360

Schwarz, D., s. Fredrickson, J. M. 72, 142, 159, 230, 287, $317,584,609,616$

Schwickhart, s. Titov 557

Scolley, C. M. 249,265

Scollo-Lavizzari, G., Akert, K. 612,620

Scott, J. W., s. Money, K. E. $308,31.9,54.3,544,561,578$

Sears, C. W., s. Jackson, M. M. 298,317

Seashore, H. G. 356, 357, 359

Seashore, H. G., Koch, G. 354

Seashore, R. H. 356

Seashore, R. H., Buxton, C. E., McCollom, I. N. 356

Segundo, J. P., s. Fujita, Y. 452,460

Sekitani, T., s. McCabe, B. F. 453, 459, 4 ij1

Sellers, E. A., s. Taylor, W. J. R. $393,397,404$

Selye, H. 571, 579

Semmes, J., Winestein, S., Ghent, L., Teuber, H. L. 8, 151

Shafer, W. A., s. Newsom, B.D. 354

Shames, I. H. 13, 151

Shanzer, S., s. Bender, M. B. $216,217,229,590,615$

Sharpless, S. K. 135, 151

Sheffey, P. L., s. Guedry, F. E. $118,145,363,365,367,374$, $378,379,381,386$

Sherrington, C. S. 579

Shideman, F. E., s. Smith, K. U. 360

Shiizu, S., s. Owada, K. 320
Shillinger, G. L., s. Von Baumgarten, R. J. 558, 559, 560, 580

Shimazu, H., Precht, W. 60, $151,290,320,452,453,454$, $457,459,462,464,489$

Shimazu, H., s. Baker, R. G. 458,460

Shimazu, H., s. Markham, C. H. 459,461

Shimazu, H., s. Precht, W. 452, $453,454,455,456,457,458$, $459,461,465,475,479,488$

Shiraki, T., s. Tokita, T. 355

Shubert, E. 85, 151

Silfverskiold, D. F., s. Behr, K. 444

Sills, N. V., s. Ross, H. E. 91, 151

Simpson, J. E., s. Maekawa, K. $590,604,618$

Sinecori 119

Singleton, G. T. 115, 126, 151, 425,449

Sirkis, Murray, D. 573

Sjöberg, A. A. 262, 265, 405, $411,449,555,579,607,620$

Skavenski, A. A., Robinson, D. A. 589,620

Skavenski, A. A., s. Ron, S. 591,619

Skoglund, J. E. 356

Slater-Hammel, A. T. 357

Smith, A. H., s. Winget, C. M. $370,373,388$

Smith, C. R. 330, 352

Smith, C. R., s. Graybiel, A. $261,262,264,333,352$

Smith, G., s. Andersson, S. 36, 110,136

Smith, K. U., Greene, D. 360

Smith, K. U., McDermid, C. D., Shideman, F. E. 360

Smith, K. U., Smith, W. M. 6, 134,152

Smith, M. J., s. Fregly, A. R. $322,333,338,351$

Smith, P., s. Chinn, H. 389, 403

Smith, S. Y., s. Coats, A. C. $304,305,316$

Smith, W. M., s. Smith, K. U. $6,134,152$

Smythies, J. R. 126, 152

Snider, R. S., s. Bard, P. 607, 615

Sokoloff, M., s. Money, K. E. 319 
Sokolovski, A. $365,368,429$, 449

Solodovnik, F. A., s. Yuganov, E. M. $554,556,580$

Solomon, G. E., Chutorian, A. M. 213,232

Sommer, H. S., s. Harris, C. S. 358

Soulairac, A., Baron, J. B. 356

Spamer, C. 463, 464, 465, 477, 489

Speers 503

Spells, K. E. 289, 320

Spells, K. E., s. Melvill Jones, G. $5,38,148,502,508,578$, 585,617

Spiegel, E. A. 392, 404, 477, 489

Spiegel, E. A., Aronson, L. 477, 489

Spiegel, E. A., Dèmètriades, T. D. $451,456,462,475,489$

Spiegel, E. A., Egyed, J., Szekely, E. 8, 152

Spiegel, E. A., Sato, G. 45̃, 458,462

Spiegel, E. A., Szekely, E. G., Moffet, R. 8, 152

Spiegel, E. A., Teschler, L. 477, 489

Spoendlin, H. H. 17, 69, 152, $290,320,515,517,518,579$

Spoor, A., s. Van Dishoeck, H. A. E. $8,22,35,117,153$, $380,384,416,444,579$

Sprague, J. M., Chambers, W. W. 478,489

Sprague, J. M., s. Chambers, W. W. 478,485

Stahle, J. 291, 294, 296, 320

Stahle, J., s. Aschan, G. 29, 136, $200,229,429,430,443$

Stark, G. 223, 225, 232

Stark, L., Vossius, G., Young, L. R. 589, 620

Stark, L., s. Young, L. R. 587, 594,620

Stavraky, G. W., s. Drake, C. G. 459,460

St.-Cyr, G. J., Fender, D. H. 589,620

Steele, J. E. 120, 123, 152, 401, 404

Steen, B., s. Jonsson, R. 360

Steer, R. W. 112, 152, 507, 510, $548,550,552,579$

Steer, R. W., Jr. 288, 310, 311, 320
Stein, S. von $277,280,357$

Steiner, F. A., s. Weber, G. 586, 620

Steinhausen, W. 69, 70, 71, 152, $415,449,502,504,513,579$

Stenger, H. H. 204, 206, 232, $437,449,451,458,462,482$, $483,484,489$

Sternfeld, s. Benson, A. J. 312

Stetson, R. H., s. Hubbard, A. W. 360

Stevens, S. S. $39,43,152$

Stewart, J. D., s. Clark, B. 23, $25,26,27,28,30,35,42,55$, $58,59,63,117,139,380,383$

Stewart, W. G., s. Manning, G. W. 390,403

Stigler, R. 88, 91, 93, 152, 164, 190

Stockwell, C. W., Gilson, R. D., Guedry, F. E. 65, 152

Stockwell, C. W.. Guedry, F. E. $108,109,110,152,256,265$

Stockwell, C. W., Turnipseed, G. T., Guedry, F. E. 311, 320

Stockwell, C. W., s. Gilson, R. D. $56,62,131,142$

Stockwell, C. W., s. Graybiel, A. 234, 262, 264

Stockwell, C. W., s. Guedry, F. E. $44,45,47,48,51,52,53$, $56,108,145$

Stone, R. W., Letko, W. 112, $113,152,544,545,546,579$

Stone, R. W., s. Letko, W. 554, 577

Storm van Leeuwen, W., s. Magnus, R. 584, 618

Struppler, A., s. Wigand, M. E. 276,280

Stuart, E. A., s. McNally, W. J. $7,17,68,115,148$

Stuart, G., s. McNally, W. H. 389,404

Stubbs, R. A., s. Johnson, W. H. 390, 391, 392, 403, 558, 576

Stuteville, P., s. Welch, K. 612, 620

Suganuma, Y., s. Tokita, T. 355

Sugie, N., Melvill Jones, G. 579

Sunahara, F. A., Johnson, W. H., Taylor, N. B. G. 393, $404,408,411,449$

Sutherland, N. S. 162, 190
Suzuki, J., Totsuka, G. 374, 387

Suzuki, J., s. Cohen, B. 586, 616

Swets, J. A. 36, 152

Szekely, E., s. Spiegel, E. A. 8, 152

Szentágothai, J. 69, 152, 165, $190,232,291,320$

Szentágothai, J., Raikovits, K. 475,489

Szentágothai, J., s. Eccles, J.C. 604,616

Tait, J. 165, 190, 277, 280

Tait, J., McNally, W. J. 543, 579

Tait, J., s. McNally, W. J. 277, $279,466,488,584,619$

Takebayshi, H., Kuriyama, T., Imamura, H., Kurihara, M., Kishi, M. 354

Takemori, S., s. Cohen, B. 116, $119,125,126,140$

Takeuchi, T., s. Tokita, T. 355

Talpis, L. 270, 280

Tashiro, K., s. Fukuda, T. 376, 377,385

Taub, E. 134, 135, 152

Taub, E., Berman, A. J. 134, 152

Taylor, N. B. J., Hunter, J., Johnson, W. H. 401, 404

Taylor, N. B., s. Best, C. H. 400,403

Taylor, N. B. J., s. Johnson, W. H. 390,403

Taylor, N. B. J., s. Noble, R. L. 393,404

Taylor, N. B. G., s. Sunahara, F. A. $393,404,408,411,449$

Taylor, W. J. R., Johnson, W. H., Sellers, E. A. 393, 397, 404

Templeton, W. B., s. Howard, I. P. $7,17,72,82,86,94,95$, $117,119,120,146,160,165$, 178,188

Ten Kate, J. H. 59, 152

Ter Braak, J. W. G. 284, 320

Terins, J. 185, 190

Terkildsen, K., s. Osterhammel, P. $375,376,377,387$

Teschler, L., s. Spiegel, E. A. 477, 489

Teuber, H. L. 7, 8, 52, 94, 130 , $152,470,489$

41 Hb. Sensory Physiology, Vol. VI/2 
Teuber, H. L., Mishkin, M. 8, Travis, R. C., Dodge, R. 44, 77, |Vendrick, A. J. H., s. Groen, J. 152 78,152

Teuber, H. L., s. Semmes, J. 8, 151

Thauer, R., Peters, G. 466, 467, $473,480,489$

Thiébaut, F., Isch, F., Collard, M., Concraux, C. 356

Thomas, D. P., Whitney, R. J. 276, 280

Thomas, E. L., s. Ackerman, U. 399, 402

Thompson, A. B., s. Graybiel, A. 342,352

Thompson, Truet, B. 573

Thornhill, R. A., s. Lowenstein, O. 496,577

Thornval, A. 270, 280

Thorpe, W. H. 382, 387

Thorton, C. L., s. Barrett, G.V. 119,136

Thulin, C. A., s. Gernandt, B.E. $268,279,452,454,460,464$, 486

Tibbling, L. 6, 152

Tibbling, L., s. Henriksson, N. G. 36,145

Timm, C. 284,320

Titov, Schwickhart 557

Tokita, T. $355,356,434,435$, 449

Tokita, T., Aoki, S., Yonekura, E., Shiraki, T., Kuroda, W., Takeuchi, T., Nakayama, S., Fujimoto, T., Aoki, M., Goto, T., Mizutani, T., Suganuma, Y. 355

Tokita, T., s. Fukuda, T. 353, $354,357,373,376,377,378$, 385

Tokita, T., s. Igarashi, M. 321, 352

Tokumasu, K., s. Goto, K. 362, 367

Torok, N. 221, 232, 365, 368, $374,375,387$

Torok, N., Guillemen, V., Barnothy, I. M. 220, 232

Torok, N., Kahn, A. 271, 280

Torok, N., s. Johnson, D. D. 375,386

Totsuka, G., s. Suzuki, J. 374, 387

Toyne, M. J., s. Wilson, M. E. 596,620

Travis, R. C. 356
Trendelenburg, W. 479, 489

Trevisan, C., s. Duensing, F. 484,486

Trincker, D. 15, 68, 69, 152, $424,427,429,432,449,452$, 454,462

Tschermak, A. 408, 411, 416, 433,449

Tschiassny, K. 377, 387

Tsuiki, Y. 429, 449

Tullio 426

Tumarkin, I. A. 25, 153

Turnipseed, G. T., s. Stockwell, C. W. 311,320

Tyč-Dumont, s. HorcholleBossavit 586

Tyler, D. B., Bard, P. 389, 390, 391, 393, 404

Uchytil, B. 276, 280, 356

Udo de Haes, H. 159, 160, 161, 182,190

Udo de Haes, H., Schöne, H. $92,109,153,163,175,179$, $182,190,294,320$

Udo de Haes, H., s. Schöne, H. $72,85,100,109,125,151$, $160,163,164,165,175,182$, 190

Uemura, T., Cohen, B. 203, $205,221,232,475,489$

Uemura, T., s. Cohen, B. 119, 125,140

Uffenorde, K. 484, 490

Ulrich, H. 68, 69, 70, 75, 153, 291, 320

Ungar, G. 482, 490

Uno, R., s. Kitahara, M. 110, $146,414,447$

Unterberger, S. 226, 232, 272, $273,280,355,490$

Updegraff, B. P., s. Collins, W. E. $370,373,384$

Vaeth, W., s. Schwartz, R. P. 360

Vaglini, F. 354

Vallenstein, E. S. 580

Vanderwolf, C. H. 612, 620

Vasil'yev, P. V., Volynkin, Yu., K. 254, 266

Vazuka, F. A. 354

Veits, C. 222, 232, 415, 427, 449

Veits, C., s. Fischer, M. H. 418, 435,445 J. $19,59,62,144,283,317$, $415,423,446,502,508,509$, $510,511,512,518,575$

Vernon, J. A., McGill, T. E., Gulick, W. I., Candland, D. K. 359

Vernon, M. D. 182,190

Versteegh, C., s. Kleyn, A. de $211,231,277,279,307,318$, $407,410,447$

Versteegh, L. 165, 190

Vilstrup, G., Vilstrup, T. 69, 70, 153

Vilstrup, T. 514, 515, 579

Vilstrup, T., s. Vilstrup, G. 69 , 70,153

Van der Vis, K. 432, 449

Visser, S. L. 200, 201, 232

Vliet, A. G. M. van, Waardenburg, P. J., Forsius, H., Eriksson, A. W. 211, 232

Vogel, K. 484, 490

Vogelsang, C. J. 380, 387

Vogt, C., Vogt, O. 609, 620

Vogt, O., s. Vogt, C. 609,620

Vogts 609

Voigt, K., s. Dichgans, J. 117, 141

Voldrich, L. 562, 579

Volokhova, N. A., s. Arlaschenko, N. I. 353

Volynkin, Yu., K., s. Vasil'yev, P. V. 254, 266

Voogd, J. 434, 449

Voots, R. J., s. Milojevic, B. 304,319

Vossius, G., s. Stark, L. 589, 620

De Vries, HI. 25, 33, 69, 70, 71, $72,75,141,432,433,449$

De Vries, Hl., Schierbeek, P. 25,141

Waardenburg, P. J., s. Vliet, A. G. M. 211,232

Wada, H., s. Saito, I. 310,320

Wade, N. J. 72, 153

Wade, N. J., Day, R. H. 72, 153

Wade, N., s. Day, R. 72, 141, 174,187

Wagman, I. H. 232, 609, 620

Waite, R., s. Graybiel, A. 103, 104, 143, 242, 244, 264

Walberg, F., Bowsher, D., Brodal, A. 268, 274, 280

Walberg, F., s. Brodal, A. 268, $278,5(5,574$ 
Waldecker, G., s. Kornhuber, H. H. 195, 231

Wallach, H., s. Köhler, W. 162, 188

Walsh, E. G. 8, 71, 73, 74, 77, $78,79,80,82,87,153,163$, $190,436,449$

Walsh, F. B., s. Ford, F. R. 353

Walther, C., s. Bechinger, D. 594,615

Walzl, E., Mountcastle, V. 7, 8, 153

Wang, S. C., s. Borison, H. L. 399,403

Wapner, S., Werner, H., Marant, R. B. 23, 153

Wapner, S., Witkin, H. A. 356

Wapner, S., s. Bauermeister, M. 85,136

Wapner, S., s. McFarland, J.H. 89, 148

Wapner, S., s. Werner, H. 94, $154,163,190,241,266$

Wapner, S., s. Witkin, H. A. $181,190,356$

Warren, B. H., s. Roman, A. J. 298,320

Watanabe, I. 354

Watanabe, T., s. Fukuda, T. $376,377,385$

Watson, J. L., s. Milojevic, B. $273,279,354$

Weaver, R. S. 120, 153, 392, 404

Weaver, R. S., s. Money, K. E. 319

Weber, G., Steiner, F. A. 586, 620

Wehner, H., s. Schaefer, K. P. 482,488

Weill, G. A., s. Babinski, J. 272, 278

Weinstein, E. A., s. Bender, M. B. 214, 229

Von Weizäcker, V. 416, 449

Welch, K., Stuteville, P. 612, 620

Wendt, G. R. 7, 66, 153, 362, $368,374,375,376,382,388$, $389,390,391,404,426,449$, 450

Wendt, G. R., s. Alexander, S. J. 262,263

Werner, H., Wapner, S., Chandler, K. A. 94, 154, 163, 190, 241,266
Werner, H., s. Bauermeister, M. 85,136

Werner, H., s. McFarland, J.H. 89,148

Werner, H., s. Wapner, S. 23, 153

Wernicke 585, 614

Wersäll, J., s. Engström, H. 69, 141

Wersäll, J., s. Flock, A. 519, 575

Wersäll, R., s. Aschan, G. 29, $136,429,430,443$

Wertheimer, M. 160, 190

Westheimer, G. 590, 620

Westheimer, G., Blair, S. M. $587,599,620$

White, H. E. 11, 154

White, P. D., s. White, W. J. 359

White, S. C., s. Minners, H. A. 358

White, W. J., Nyberg, J. W., White, P. D., Grimes, R.H., Finney, L. M. 359

Whiteside, T. C. D., s. Benson, A. J. 262, 263, 299, 300, 316, 550,573

Whiteside, T. C. D., s. Niven, J. I. 262, 265

Whiteside, T. D. M., Graybiel, A., Niven, J. I. 35, 154, 256, 266

Whiteside, W. H., s. Graybiel, A. 575

Whitney, E. 359

Whitney, R. J., s. Thomas, D. P. 276, 280

Wiesel, T. N., s. Hubel, D. H. 172,188

Wigand, M. E., Struppler, A. 276,280

Wiggers, C. J. 570, 580

Wilcox, J. G., s. Miller, E. F. II. 235,265

Williams, D. J. 437, 438, 450

Wilson, M. E., Toyne, M. J. 596,620

Wilson, T. G., Pike, F. H. 468, 490

Winestein, S., s. Semmes, J. 8, 151

Winget, C. M., Smith, A. H. 370,388

Winget, C. M., Smith, A. H., Kelly, C. F. 373, 388

Winkler, C. 468, 490
Winston, J. 482, 490

Wirth, G. 354

Wist, E., s. Brandt, Th. 119, 125,138

Wist, E. R., s. Schmidt, C. L. 607,620

Witkin, H. A. 109, 110, 154, $160,162,165,182,190,241$, 266

Witkin, H. A., Asch, S. E. 160, $162,182,190$

Witkin, H. A., Lewis, H. B., Hertzman, M., Machover, K., Meissner, P. B., Wapner, S. 181, 190

Witkin, H. A., Wapner, S. 356

Witkin, H. A., s. Asch, S. E. $160,162,185$

Witkin, H. A., s. Wapner, S. 356

De Wit, G. 353, 390, 403, 406, $408,411,430,450$

Wittmaack, K., s. Bárány, R. $270,271,278$

Wodak, E. 268, 272, 275, 280, 418,450

Wodak, E., Fischer, M. H. 270, 280

Wodak, E., s. Fischer, M. H. $269,270,271,272,274,276$, $278,429,433,445$

Woellner, R. C., Graybiel, A. $159,190,239,266,525,580$

Wojatschek, W. 405, 411, 450

Wolfe, J. W. 115, 126, 154, 364, 368

Wolfe, J. W., s. Brown, J. H. 60,138

Wolfe, J. W., s. Llinás, R. 599, 608,618

Wood, C. D. 402, 404

Wood, C. D., s. Fregly, A. R. 322,351

Wood, C. D., s. Graybiel, A. 257, 264, 402, 403

Wood, J. D., s. Money, K. E. 126,149

Wood, R. W. 160, 190

Woolsey, C. N., s. Bard, P. 607, 615

Woolsey, C., s. Hampson, J. 598,617

Worchel, P., Dallenbach, K.M. 354

Worchel, P., s. Bittermann, M. E. 162,186 
Worden, F. G., s. Schmitt, F. | York, E., Brown, K. R., Gold-|Youngermann, W. M. 202, 232 O. $602,606,607,611,613$

Wrenn, L. G. 573

Wright, G., s. Barber, H. O. 201, 206, 229, 365, 366

Wright, J. H., s. Gescheider, G. A. 85,142 fien, A. 359

Yoshida, M., s. Ito, M. 587, 605, 617

Young, F. A., s. Crampton, G. H. 119,140

Young, H. H. 160, 190

Wrigley, W., s. Draper, C. S. 496,576

Wüst, H. 223, 232

Wulfften Palthe, P. M. van 406 , $411,425,450$

Wurtz, R. H., Goldberg, M. E. $217,232,604,620$

Yacorzynski, G., s. Halstead, W. 373,386

Yagura, S., s. Saito, I. 310, 320

Yamamoto, M., s. Ito, M. 586, 617

Yao, T. Li, s. Young, L. R. 502, $524,525,530,539,546,580$

Yemel'yanov, M. D., s. Galle, R. R. 359

Yonekura, E., s. Tokita, T. 355

Young, H. H., Meiri, J. L. 165, 190

Young, L. R. 109, 154, 282, 285, $320,530,580$

Young, L., Meiry, J. 71, 74, $154,530,580$

Young, L. R., Meiry, J. L., Yao, T. Li. 502, 524, 525, $530,539,546,580$

Young, L., Oman, C. M. 42, 56, $64,154,296,306,320,509$, $515,516,580$

Young, L. R., Stark, L. 587, 594,620

Yuganov, Ye. M. 298, 306, 320, $393,402,404$

Yuganov, E. M., Gorshikov, A. L., Kasyian, I. I., Bryanov, I. I., Kolosov, I. A., Kopanev, V. I., Lebeden, V. I., Popov, N. I., Solodovnik, F. A. $554,556,580$

Yugatov, s. Feoktistov 556

Zarriello, J. J., s. Graybiel, A. $131,143,353,392,403,567$, 575

Zilstorff, K., s. Osterhammel, P. 375, 376, 377, 387

Zilstorff-Pedersen, K., Peitersen, E., 273, 274, 280, 355

Zilstorff-Pedersen, K., s. Peitersen, E. 272, 274, 275, 276, 280,355

Young, L., s. Dichgans, J. 119, Zippel, H. P., s. Domagk, G. F. 125,141

Young, L. R., s. Stark, L. 589, 620 482,485

Ziter, F. A., s. Bray, P. F. 213, 229 


\section{Subject Index}

abducens motoneurons 458

-, nystagmus rhythms 586

- paralysis 8

ability to indicate vertical 91

ablation experiments and compensation 475

abnormal eye motions 239

- oculomotor syndrom 207

abnormally fatigable patients, vestibular responses of 361

absence of gravity 252,254

- of position sense 88

- of vision during rotation 116

Abweichreaktion, caloric stimulation 271

acapnia and motion sickness 400

accelerated free fall 555

acceleration, angular, see angular acceleration

-, centrifugal 417

-, centripetal $79,82,107,282,286,287$, $299,302,498,542$

-, Coriolis- 120, 283, 298, 315, 499

-, gravitational, see gravitational acceleration

-, high-magnitude linear 107

-, horizontal 255

-, - linear, changing 105,106

-, - - discrimination from tilt 105

-, illusory $543,548,557,561$

-, linear, see linear acceleration

-, multiplanar 392,393

一, rotatory 415

-, spurious 432

—, sustained $7,9,107,298,304$

-, tangential $282,283,286$

- , time varying linear 308,312

一, transient 540

-, measurement of 499,514

-, perception of 554

-, otolith response to 533

-, rotating linear vector of 546,548

-, sinusoidal input of 523

- -dependent otolith signals 563

- -step stimulus $20,24,523$

- receptors 282

- registrography 277,359

- vectors, angular 12,15

- - linear $12,286,289,290,546,548$ accelerators, horizontal, experiments with 106

acceleratory stimuli, nomenclature of 10

- - resolution of 13

accelerometer 359

-, angular $23,496,498,503,515,520$

-, conventional 563

-, differentiating $520,522,563$

-, integrating $503,520,530$

-, linear 496, 498, 520, 530

accommodation of nystagmus and turning sensation 134

accuracy of mean judgments 84

acetylcholine and motion sickness 401, 410

Achilles tendon reflex 276

achromatopsia, nystagmus in 211

acoustic neuroma $196,222,228,229,324$, 333,335

- trauma 336

actions, shifting focus of 614

activity, vestibular cortical 8

acuity, visual, see visual acuity

acute alcohol ataxia and intactness of vestibular apparatus 350

adaptation 173,369

-, heterolateral 425

-, homolateral 425

- to angular acceleration $58 \mathrm{ff}$

- in the caloric response 306

- of canal neurons 510,552

- of canal signals $294,508,509,512$

- to constant rotation 339

- for constant velocity 515

- of control of body movements 510

- effects $42,45,50$

-, endolymph flow/cupula 515

- model 64

- of nystagmus $134,508,510$

- to sea-sickness 406,408

-, Steinhausen model 506,508

- to tilt 72,90

- time constant 296, 297, 315

- of turning sensation 134

- in vestibular organs $369,423,424,567$

adaptive coupling, semicircular canal 296

ADH during motion sickness 401

adiadochokinesis 605

adjustment 464 
adjustment of nystagmus and turning sensation 134

adrenaline and motion sickness 397,410

- , recovery of nystagmus by 362

adversive seizures 215

A-effect, see Aubert effect

aerobatic pilots, vestibular habituation 376

aerospace flight and motion sickness 398, $400,401,402$

- navigation 494

- travel 392

aetiology of motion sickness 390

afferent neurons, primary, stimulation by linear acceleration 284

afferents, eye muscle- 598

- from limb joints 584

-, macular 290

- from mechanoreceptors 605

-, neck. 584

-, somato-sensory 479

-, spinoreticular 481

African parrot, nystagmus 370

aftereffect of alcohol on nystagmus 202

一, optokinetic 118, 119

-, rotation - 92

afterimages, visual 106

afternystagmus, optokinetic $125,225,226$, 371

after-reaction, primary 61

after-sensations, phasic secondary 433

-, primary 29

-, rhythmic 419

- of rotation 418,419

- cupulogram 429

agoraphobia and vertigo 438

agravitoinertial forces 236,237

aircrew, see astronauts

airplane autopilot, determination of the vertical 538

akinesia 601, 608, 609

akinetic mutism 613

Åland eye disease 211

alcohol and compensation of vestibular lesions 482

-, effect on otolith organ function 258

- and vertigo 437,438

-, effect on visual acuity 130

- aftereffects on nystagmus 202

- induced ataxia 346,350

- ingestion and stepping test 275

- intoxication $130,205,425$

- nystagmus 307,365

alerting stimulus 374

alertness control 362

Alexander's Law 308

alkali reserve during motion sickness 401

Ames MCRP devices 117 amphetamine, influence on compensatory processes 482

- and motion sickness 402

- and nystagmus 364,365

ampullar messages 163

- receptors 282, 312

- - , first- and second order neurons of 287

- - gravitational acceleration as adequate stimulus 291

- -, stimulation by linear acceleration 283

— - thermal stimulation 306

- responses, suppression of 302

anaemia, cerebral 398

- and vertigo 438

anesthesia, effect on habituation of rotationinduced head nystagmus 361

- and vestibular sensation 425

angle, phase-, see phase angle

— of tilt 242

angular acceleration $12,15,27,282,362$, 515

- - constant 24

- -, multi-planar, and motion sickness 392

- - pendular 223

- -, simple, subjective reactions to 21

- -, unidirectional 223

- -, adaptation to 58

- , axis of 16

- - and cupula deflection 21, 24, 26

- -, interaction with linear acceleration $281,284,312$

- -, magnitude of 16

- - modification of the response to - by linear acceleration $281 \mathrm{ff}$

$-\ldots$, pendular eye deviations during 211 , 212

-- and nystagmus $62,220,291,302$, 377

- - thresholds of perception $23 \mathrm{ff}$

- - and vestibular responses 223

- - vector 116

- accelerometer $23,496,498,503,515$, 520

- displacement estimation $44,49,51$

- distortion phenomenon 162

- impulse 20,121, 122

- momentum, changes in 120,121

- motion and motion sickness 391

- oscillation in the yaw 312,313

- -, whole-body 127

- position relative to gravity 18

- sensors 500, 501

- velocity, canal-generated 122,515

- - constant 113

- -, subjective $44,47,421,422$

-, , - , direct measures of 43 
angular velocity, subjective, and information theory 56

- _, - , magnitude estimation of $39 \mathrm{ff}$

-,,- , and nystagmus 66

- - impulses 20

- - information, otolith system 105,112

- - transducers 20

- - canal responses to 502

- - and cupula deflection 21, 421

- - perception of $13,18,56,125$

- - , sensation of 424

animal hypnosis 362

animals, foveate and nonfoveate, nystagmus in 594

-, labyrinthine-defective 501

-, compensation of vestibular lesions $463 \mathrm{ff}$

- with inoperative canals $543 \mathrm{ff}$

-, motion sickness in 405,427

-, spontaneous nystagmus in 211

-, vestibular habituation in 370

anisometropia 207

anomaly of foveal vision 208

anticompensatory reactions 543,544

antidiuresis and motion sickness 397,401

antigravity muscles 268

- stretch reflex 585

antihistamines and motion sickness 402, 410,570

anxiety 179

apathy 614

aphasia, frontal 614

-, Broca's 614

-, Wernicke's 614

apparent angle of tilt 242

- displacement of visual target 380

- horizontal 162, 241, 558

- motion, reversal in 68

- - of the environment $197,242,380$, 593

- tilt 119

- vertical $86,160,162,169,170,174,176$, $178,179,180,181,182,241$

- - as a function of lateral body tilt 161 , 242

- - in or out of water 248,249

apraxia 599,600

-, gaze - 217

-, oculomotor 218

appropriate stimulus for semicircular canals 415

- - of vestibular organ 414

arachnoiditis and vertigo 440

arc of uncertainty $84,85,86,88,89$

- — , see also $\mathrm{U}$ deg

archicerebellum and motion sickness $607 \mathrm{ff}$ archicerebellum, visual control of the vestibular-ocular reflex arc 590

area 8 (frontal eye field) 611,612

-, pretectal 588

-, Rolandic 609, 610

-, striate, destruction of 218

-, vestibular projection - 8

areas, cortical, and vestibular sensations 7

-, sensory association - 599

arm tonus reaction 227,270

Armtonusreaktion 227, 270

arousal 362

- effects 66

- nystagmus 261, 363

-, vestibular responses to $361 \mathrm{ff}$

artherosclerosis and vertigo 438,443

arteriosclerotic lesions 205

artery, vertebral 196

一, vertebro-basilar 207

association cortex 599

astronauts $104,244,254,261,290,298,324$, $402,555,556,557$

-, see also pilots

-, vestibular sensations 425

asymmetry index 235

- in vestibular influences on oculomotor nuclei 455

ataxia, alcohol-induced 346,350

-, cerebellar 277

-, compensated vestibular 328

-, induced vestibular 338,350

-, residual 345

-, rotation-induced 344

-, spontaneous vestibular $324,336,350$

-, vestibular, measurement in man $321 \mathrm{ff}$

- of visually guided hand movements 218

-, effect of age and sex on 324,325

- in normals 324

- test battery 322

- test methods, bibliography of 352

- tests in labyrinthine-defective subjects $324,326,327,328,329,330,331,333,335$, $336,344,345,346,347$

ataxiagraphic methods 355

ataxiametric methods 355

athetosis 608

atrophy, cerebellar 226

-, cerebellocortical $583,596,598,603,604$

—, Friedreich's 598

-, transneuronal, of oculomotor neurons 598

atropine and motion sickness 410

attacks of vertigo $195 \mathrm{ff}$

attention to vestibular sensations 67

-, visual 612

- habituation 135,136

- shifts and linear displacement estimation 106 
Aubert effect $\quad 86,94,96,161,241$

Aubert-Fleischl paradox 52

audiogyral illusion 432

- phenomena 417

audiometry 234

autistic children, nystagmus in 365

autocompensation $166,172,173$

-, feed-back - 176

-, visual 169

autogyral effect of body and visual reference $28,36,117,118$

autokinesis, rotatory 242

— for a point source of light 242

automatic holding 194

autonomic effects of motion sickness 392

- nervous system and motion sickness 399 avitaminosis and vertigo 438

awareness, cognitive, of vestibular information 135

axis, primary 169,170

-, secondary 169,170

- of angular acceleration 16

Babinski sign 218

balance, poor, during swimming 91

- reactions 277

- tests 90

ballism 608

barbecue rotation experiments 548

barbiturate anesthesia 584

barbiturates, intoxication by 205,590

Bárány test 423,427

basal ganglia 614

- - diseases of 601

- - inputs from motor cortex 602

- -, lesions in 608

- - as ramp generator 608

basic components of an inertial system 500

- principles of inertial navigation 498

Bechterew compensation $463,472,473,474$, 475,476

- compensatory nystagmus $456,457,483$, 484

bending 530

benign paroxysmal positional nystagmus 437, 439, 441

Bereitschaftspotential 600

bicomponent theory 164

bilateral labyrinthine defective persons (BL-Ds) 324, 326, 327, 328, 329, 330, 331, $336,338,344,345,346,347$

- loss of labyrinth function 164

- loss of vestibular function 332

binocular coordination 215

Biperiden 215

birds, compensation of vestibular lesions $463,465,472,477,479$ birds, nystagmus $\quad 219,370,371,372,373$, 378

- , static function of otolith organs 165

birth trauma 202

blepharospasm 440

blind, cortically 218

- spots of the labyrinths 417

- - of the otolithic organs $80,242,436$

blindfolded observers 90

blindfold walking 272

blindness and eye position $\quad 587$

-, involuntary spontaneous eye movements in 210

- and motion sickness 607

- and vestibular sensation 426

blood acetylcholine and motion sickness 401

- flow and motion sickness 394, 395

- in the perilymph, nystagmus 206

- pressure and motion sickness 393, 395

- - and vertigo 196, 438

- -supply, vertebro-basilar 228

blurred vision 195

Bode plot of canal responses 505

body, see also whole-body

-, displacement of 169

-, force field on 87

-, orientation relative to 85

- angle motions, frequency spectra of 251

- axis dependence 110

- control and vestibular system 500

- inclination 181

- movements, illusions of 563

- - path of 111

- orientation 156

- - unexpected perceived changes in 125

- position 170

- - , stabilization of 194,583

- rotation, perception of 118

- reference versus visual reference 106

- surface, pressure on 163

- -sway motion 253

- tilt 182, 242

- -, estimate of 83

- - influence on orthogonality of space perception 162

- tonus, asymmetric 163

brainstem 588, 601

- damage and spontaneous nystagmus 202

- disease, square-wave jerks 212

-, ischemia of 204

-, lesions of $196,202,216,226$

brain tumors and vertigo 440

Broca's aphasia 614

一, field 614

bulbar lesions 484

- palsy, progressive 228 
buoyancy cues 91

buttocks, anesthetizing of 87

butyryperazine 481

caffein 481,482

calcium, content during motion sickness 401

caloric habituation 372,373

- irrigation of the ear 115

- nystagmus, see nystagmus, caloric

- responses 113, 229

- -, acoustic neuroma $222,333,335$

- -, adaptive mechanisms of 306

- - evaluation of 220,221

- - influence of visual fixation 222

- -, misinterpretations 221

- - and recovery nystagmus 204

- stimulation $220,269,270,272,276,362$, $381,418,434,435$

- stimuli, measurement of vestibulo-spinal responses to 274

- test, head- and body position 115, 220

- - hemispheric lesions 222

- - in labyrinthine-defective subjects $331,335,483$

- - methods of $222,226,303$

canal, see also semicircular canal, canals

-, cross-section of 507

- afferents, positional responses 284, 285

- - primary, activity of 287

- -dependent cells $\mathbf{5 4 9}$

- - responses, suppression of 123

- - units, velocity information by 112

- function, subjective and objective indicants of 295

- -generated angular velocity 122

- inputs, convergence of 287

- model, see Steinhausen model

- neurons, primary $509,510,552$

- otolith interactions 121, 256, 259

- receptors 251

- response to angular velocity 502

- - to gravireceptor stimulation 295

- - to gravitational acceleration 292

- - after habituation 132

- - during head tilts 132

_ - mathematical model of 296

- -, postrotational 92

- -, suppression of 296

- - to weightlessness 298

- sickness 262

- system, natural frequency of

- units, activity of 287

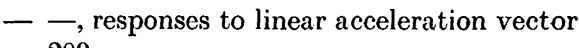
289

canals, horizontal, vestibular neurons $\mathbf{4 5 4}$

-, inoperative, in animals 543

-, lateral 121 canals, lateral, adaptation of the signal from 294

,,-- central suppression of the signals from 294

-, vertical, pathology of 432

carbon dioxide, content during motion sickness 401

cardiac action and motion sickness 393

cardiazole 482

carotid obstruction 196

cat, compensation of vestibular lesions 470 , $472,474,476,478$

-, with defective canals 544

-, nystagmus in $211,371,372,374$

-, response to linear acceleration $\mathbf{5 4 8}$

catatonic patients, vestibular responses 361

catecholamines, content during motion sickness 401

cells at the apex of the crista 515,553

-, canal-dependent 549

-, Ewaldian 286, 288

-, granular 603,605

-, non-Ewaldian 288

-, otolithic, see otolithic cells

-, Purkinje- 587, 603, 605, 608

-, rotation-dependent 549,567

central compensation of vestibular function 460

- factors, habituation 381

- nervous system, response to linear acceleration 548

- - - diseases and vertigo 438

centrifugal acceleration, sensation of 417

- forces 165

centrifugation under water 235

centrifuge $81,83,96,97,107,110,111,242$, $259,299,392,416,435,550$

-, counterrotating 111,549

- stimulus 79

— studies 95, 96, 235, 239

centripetal acceleration $79,82,107,282$, $286,287,299,302,498,542$

cerebellar ataxia 277

- atrophy 226

- cortex 588

- - , eye muscle afferent projection to 598

- - peripheral mossy afferents to 605

- - , removing of 583,587

- - , saccadic function of 602

- -, step generator 599

- disease, square-wave jerks 212

- encephalopathy, paraneoplastic 213

- extirpation in pigeons 477

- inhibition 453

- nodulus, lesions of 205

- nuclei 603 
cerebellar nuclei, analogy in function with vestibular nuclei 607

- $\ldots$ and eye movements $586,587,588$

- - , function of $605 \mathrm{ff}$

- - intoxication of 210

- -, lesions of, and nystagmus 199, 217

- step and holding functions 604

- tumor and saccades 596

- - and vertigo 440,441

cerebellectomy $584,586,589$

- in guinea-pigs 478

- and nystagmus 599

— and saccades 599

cerebellocortical atrophy $583,596,598$, 603,604

- lesions 589, 597, 605

cerebello-nuclear lesions 605

cerebellopontile arachnoiditis 440

cerebello-pontine angle, acoustic neuroma 228

cerebellum $115,116,217,475,582,588,614$

-, compensation of vestibular function 460

-, diseases of basic ganglia 601

- in emotional processes 126

-, influence on compensation of vestibular lesions $477 \mathrm{ff}$

-, inputs from motor cortex 602

-, lesions of 226,228

-, nuclear and cortical functions in 587

- and saccades 596, 598

-, second vestibular integration $\quad 589$

一, vestibular tracts in 390

- and visual inhibition of vestibular nystagmus 116

cerebral anaemia during aerospace flight 398

- concussion 204

- contusion 204

- cortex, influence on compensation of vestibular lesions $\quad 475 \mathrm{ff}$

- - influence on postural functions 475, 477,588

- - , influence on vestibular functions 475 , 603

- - influence on visual functions 475

- - visual regulation of eye position 587

- deficiency, compensation of $\mathbf{4 7 5}$

- hemispheres, vascular lesions in 484

- lesions, space coordinates 162

- potentials preceding voluntary movements 600,601

cerebrovascular accidents and vertigo $\mathbf{4 4 2}$

- insuffiency 195,336

cerebrum, removal of, and compensation 475

cervical nystagmus 436

- root lesions 206, 584

- vertigo 436 cervico-ocular reflex 223

change of gravity, response to 527

- in-orientation information, otolith system 105

- -in-position $\quad 90,92$

- - - memory of 90

- - - information $18,90,112$

- - units 72

changes in angular momentum 120

- in direction 111

- in the distal environment 169

changing horizontal linear acceleration 105 , 106,107

"channel capacity" for perception of angular velocity 56,57

chemical aspects of motion sickness 401

chimpanzee, motion sickness 427

-, spontaneous nystagmus 211

chlorpromazine 364,481

chorea 608

cinnarizine $258,364,410$

claustrophobia and vertigo 438

climbing fiber action, parametric gain adjustment via - 604

- sensation 123,125

clinging 179

clinical history of vertigo 195,197

clonic upward eye movements 215

clopenthixol 481

coarse saccade 596

cochlear symptoms 195

Cogan's syndrome and vertigo 440

cognitive awareness of vestibular information 135

color blindness 211

collicular lesions 217

colliculus, superior $217,596,612$

commissural fibers, cutting of 457

- inhibition, compensation of 459

- pathways 290

commissure, posterior 217

compensation 156

-, Bechterew - 463, 472, 473, 474, 475, 476

-, external and internal 159, 174

-, feed-back - 173,176

-, feed-forward - 173,174

-, latent 472

-, optical 177

-, Ruttin - 472

-, vestibular $177,451,460$

- of commissural inhibition 459

- of labyrinthectomy $463 \mathrm{ff}$

- of vestibular lesions $463 \mathrm{ff}$

-, time-course of 465

- principle $157,158,169$

compensatory errors 160

- eye movements 225,234 
compensatory function 158,159

- nystagmus 310

_ - Bechterew's 456, 457, 463

- oculogyral illusion 380,381

- righting reactions 277,543

- variable 173,177

- vestibular responses 295

compression of the vertebral artery 196

concept of threshold 35

concomitant squint 207,208

conditioning of a single neuron 567

conflict theory 568

congenital nystagmus 198, 202, 208, 209, $210,211,219,228,426$

conjugate deviation 454

consciousness 425

- in aerospace flight 398

conscious perception 418

consistent position signaling 112

constancy, directional 157

-, motion 172

-, vertical $157,166,172$

- of space perception 156

- of visual space 197

- problem $\mathbf{1 5 7}$

constant, Mulder's 30

- angular acceleration 24

- angular velocity 113

- speed off-vertical rotation 113

- stimulus of gravity $259 \mathrm{f}$

- velocity rotation 111,288

contour detection 172

conventional accelerometers 563

convergence of canal and gravireceptor inputs 287

- retractory nystagmus 217

- of somatic and vestibular afferents to motor cortex 610

convergent detection 177,178

convulsive disorders 195

coordinate systems, perceptual 164

Coriolis acceleration $120,283,298,315,499$

- cross-coupled reaction, vestibular 133

- - stimuli, vestibular 124, 125

- - - perceptual phenomena of 123

- effect $119,120,125,131,553,607$

- forces 423

- - and motion sickness 408

- illusion $553 \mathrm{ff}$

- nystagmus test 339

- stimulation $377,381,382,527,563$

- torque stimulus 133

- vestibular reaction 120

corneoretinal potential, drug effect on 364

corpus callosum, section of 216

correction 156

- principle $177,180,181,182$ correction saccades 594,596

cortex, cerebellar, see cerebellar cortex

-, cerebral, see cerebral cortex

-, cingulate 614

- , frontal 611,614

-, infero-temporal 611

-, motor - $217,600,602,609,610$

-, orbital 126, 613

-, sensorimotor 609

-, striate 611

-, tempero-basal 611

-, nystagmogenic zones of 475

cortical areas and vestibular sensations 7

- association areas 599

- evoked potentials 9

- lesions and gaze paralysis 216,217

- stimulation, influence on nystagmus 477

- vestibular representation 7

cortically blind 218

cortico-cortical association fibers 612

- connections from the striate cortex 611

- reflex arc 600

corticofugal fibers, lesion of $\mathbf{5 8 7}$

corticosteroids, content during motion sickness 401

cosmonauts, see astronauts

cosmos sickness 402

counterrolling, dynamic $68,525,526,527$, 528,546

-, ocular 68, 94, 103, 226, 234, 235, 239, 252, 259, 517, 525, 526, 554, 563

-, static 525,526

counterrotation 286

- on a centrifuge 111,549

countertorsion, ocular $159,174,178$

cranial nerve, eighth, and motion sickness 390

crista ampullaris 14

-, type I cells 515,553

-, type II cells 515

cristae, adequate stimulation of 284

-, response to gravity 284

-, stimulation by linear acceleration 284

cross-coupling effect $119,120,121,125,131$

- stimulation of the canals 554

cues, buoyancy - 91

-, kinesthetic 527

-, nonvisual, and visually perceived direction of space $\mathbf{2 4 1}$

-, postural direction $163 \mathrm{ff}$

-, somesthetic, eliminated 545

-, somatosensory $88,90,91,93,94,113$

-, vestibular and nonvestibular, reduced 90

cue system, postural 179

cupula 14

-, density of $285,552,553$

-, elasticity of 506,508 
cupula, hysteresis in 419

-, measurement of acceleration 514

-, measurement of velocity 514

-, model of 289

-, motion of 513

-, specific gravity of 285

-, time constant of 285

- deflection and angular acceleration $24,26,27,29$

- - and angular velocity 21

- - by centripetal acceleration 286

- - by gravity 294

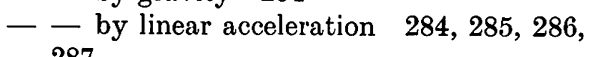
287

- -, peak - 38

- - and sustained nystagmus 301

- - threshold methods and working equations 37

- displacement $47,502,503$

- dynamics 25

— 's elastic restoring force 29

- endolymph loop 19

- - system $31,38,415$

- recovery, working equations 38

- return 29

- sensory cells, asymmetrical response 514

cupular stimulus, quantitative estimation 427

cupulogram $28,29,30,31,35,408,409$, $420,422,433$

- and adaptation 429

-, after-sensation - 429

-, nystagmus - 421,430

-, sensation - $421,422,423,428$

-, working equations 38

cupulometry $419,420,428,429,434$

-, clinical 415

-, sinusoidal 66

- after-reactions 433

cutting of commissural fibers $\mathbf{4 5 7}$

cyclic modulation 111,113

cyclizine, and motion sickness 402

damped spring system $19,33,38$

dancers, nystagmus in $369,376,377$

-, vestibular sensations in 425

data processing 500

deaf children 436

$-\operatorname{man} 90,95$

- mutes 7

- - and motion sickness 390,405

deafferented type I vestibular neurons 459

deafness, hereditary 436

-, long-standing 336

decay of the nystagmus $62,111,123$

decelcration from off-vertical rotation 113

-, nystagmus after 378,548 deceleration, sensations during 22

decerebellation and vestibular sensation 426 decerebration and vestibular sensation 426 deep reflexes to vestibular stimuli 276

- sea divers 324

- sensibility 88

deflection, utriculofugal 15

-, utriculopetal 15

- of the cupula, see cupula-deflection

degeneration of synaptic endings 459

dehydrogenase, content during motion sickness 401

Deiters' nucleus 268

delay time, cerebellar cortex fibers 604

- - in the initial tilt position 85

demyelination, dentate nuclei 213

dentate nuclei, demyelination 213

- nucleus and spontaneous eye movements 213

destruction of one striate area 218

- of the vestibular nerve 203

detection of angular acceleration by the canals 509

-, convergent 177,178

-, displacement - 34

-, rotation - 34

determination, see also perception, sensation

- of displacement $538 \mathrm{ff}$

- of linear velocity $538 \mathrm{ff}$

- of velocity and position $497 \mathrm{ff}$

- of the vertical $534 \mathrm{ff}$

deviations from ideal veridicality 161

diabetes and vestibular sensation 432,438

diencephalic lesions 214

- tumor 203, 214

difference limens 34

differentiating accelerometer $520,522,563$

diphenylhydantoin, intoxication by 205

diplopia and vertigo 438

direction, perverted, of caloric nystagmus 221

-, visually perceived, in space 238,241

- , changes in 111

-, memory of 104

- of linear acceleration 81

- of space, nonvisually perceived

- of spontaneous nystagmus 202

- of the vertical, sensed 542

- -reversing nystagmus 113

- cues, kinesthetic 163

- -, optical $163,166,178$

- -, postural $163 \mathrm{ff}$

- -, tactile 163

_ - vestibular 163, 164

- - for horizontality 169

— for verticality 169 
directional asymmetry 290

- constancy 157

- difference in dynamic vision

- - in nystagmus 127,129

- induction $160,178,182$

- predominance of nystagmus 452

- sensitivity 290

disequilibrium, postural 239, 257

disinhibition of primitive drives 613

disk protrusion 206

disorders, convulsive 195

-, psychogenic 336

disorientation due to head movements 556

displacement, angular 44, 49,51

-, linear 106

一, perceived 106

-, tangential 70

-, target - 106

-, true 106

— of the body 169

-, determination of $538 \mathrm{ff}$

- of the otolith membrane 17

- of otoliths 69,71

- detection 34

- measures, subjective 48

distal stimulus 158

distortion, angular 162

distribution of pressure on the body surface 163

disturbance of eye movements 215

- of optokinetic nystagmus 218

disturbances, reflex vestibular 257, 262

divers, deep-sea - 324

diving, sensation of 123

dizziness $119,369,438,443$

一, episodic 330

dog, compensation of vestibular lesions 471 , 472,479

-, spontaneous nystagmus 211

dorsal light reactions 178,180

- roots 479,584

dorsomedial nucleus, afferents from hypothalamus and limbic system 612

double vision 195

dramamine and motion sickness 410

drive to act 612,613

drop-attacks 195

drowsiness 212

drug intoxication 215

drugs and compensation of vestibular lesions 481

-, effect on nystagmus 364,365

-, effect on otolith organ function 258

-, suppression of motion sickness by 401 , 402,410

dynabalometer 356 dynamic counterrolling $68,525,526,527$, 528,546

- otolith stimuli 68

- responses of otolithic cells $519,520,525$, 532,533

dynamics of the otoliths 69,71

dysacousis and caloric stimulation 434

dysfunction, labyrinthine 87

dysmetria 609

- of saccadic eye movement 596, 598, 603

- of step movements 605

dysmorphosia 162

dystrophy, ocular muscle - 215

E $600 \quad 482$

ear, caloric irrigation of - 115

-, chronic processes in the -, and vertigo 442

-, inner, diseases of 202,275

-, -, vascular lesion 195

earth, reflex actions relativ to 18

- reference, otolith-detected 115

- -, vision-detected 115

eccentric gaze positions $\quad 589$

- rotation 299

E-effect, see Müller-effect

EEG, angular accelerations and 362

- and nystagmus 362

efferent vestibular system 285

egocentric orientation ability 91

- positioning of the line relative to the body 95

Einstein's equivalence principle 103, 104 elasmobranchs, canal responses 502, 508, $509,510,552$

-, otolith responses 519

一, vestibular receptors 284

elasticity of the cupula 506,508

electric stimulation and vertigo 438

electrobasometer, force plates - 359

electronystagmography 200

electrooculogram 199, 200

elevator, motion sickness 391

- illusion 262

ellipse of uncertainty, head-up position 89

emesis 396,401

emotional processes, cerebellum in 126

encephalitis, square-wave jerks 212

- and vertigo 439,442

-, viral, and ocular myoclonus 213

encephalopathy, cerebellar 213

endolymph 14

一, density of $285,552,553$

-, protein content of 562

-, redistribution of 288

- , specific gravity of 16,303 
endolymph, viscosity of 507,562

- displacement 502,552

- flow, utriculopetal and utriculofugal

453

- pressure, pathology 562

endolymphatic cavity, hydrops in 561

- fluids 562

- systems, model of canal with 289

endolymphaticus sac 561, 562

eosinophils, content during motion sickness 401

ephedrin and motion sickness 402

epilepsy, petit mal - 215

-, temporal lobe - 196

epileptic nystagmus 215

— vertigo 196, 439, 441

equilibrium, labile 168

- , postural 234, 250, 261, 333, 346

-, 一, bibliography of 352

-, function of lagena 559

- in lunar walk 254

-, maintenance of 250

-, organs of 495

- responses, postural 156

equivalence, optic-vestibular 177

- principle, Einstein's 103, 104

equivalent signals 177,178

erect position, thresholds 82

Erholungsnystagmus 484

error correction 179

- detection 179

errors, compensatory 160

estimation of angular displacement 51

- of linear displacement 106

- of plane of the utricle 98

- of body tilt 83

- of verticality 83,84

evaluation of caloric responses 220,221

Ewaldian cells 286, 288

Ewald's law 430, 472, 514

excitation and nystagmus 362

excitement, vestibular responses to 361 , 362

exploration of space 251

extensor plasticity 585

- tonus 268

external compensation 159,174

- ophthalmoplegia 275

- spatial reference system 241

extraocular muscle palsies 215

- nerve palsy 215

extrapersonal space, perception of 238,261 eye, see also ocular

- deviations, pendular 211,212

- disease, Åland 211

— field, frontal, function of $586,592,611 \mathrm{ff}$

- fits, tonic 215 eye-hand coordination 612

- head-body incoordination 612

- movements, see also nystagmus, saccades

- -, abnormal 239

- - clonic upward 215

- - compensatory 225,234

- -, involuntary 197

- - involuntary spontaneous, in blindness 210

- -, nonnystagmic 212

- -, pursuit 199

,,- , smooth $199,215,216,219,587$, 588

- -, rapid 362

- -, rotatory 202

- - saccadic $216,590,591,600$

- -, seesaw 203

- -, spontaneous, and myorhythmia 213

- -, vestibular 201

- - visual guided 215,217

- -, voluntary 600,601

- -, , in blindness 211

- - and angular oscillation in the yaw 313

- -, disorder of 583

- -, extraocular muscle afferents 586

- - in fish 560

- after labyrinthectomy 451

- - after neurotomy of the VIII nerve 451

-- , seeing during 130

- muscles 588

- -, nuclei for 439

- - proprioceptive feedback from 599

- - afferents, projection to the cerebellar cortex 598

- - stretch 586

- position in blind man 587

- - optokinetik and vestibular regulation of 197

- - , stabilization of 194,587

- - control, neural mechanisms of 588

- postures, vestibular stabilization of 583 , $585,587,588$

- tracking, predictive 589

fainting fits and vertigo 443

fall, accelerated free $\mathbf{5 5 5}$

fastigial nuclei 479

fatigue and vestibular responses 361,369

fear of heights 195

- reaction 125,131

feed-back, optical 169

-, proprioceptive, from eye muscles 599

-, visual 587

- autocompensation 176

- compensation 173,176 
feed-forward compensation 173,174

fenestration operations 430

Ferris wheel effect $112,113,545,548,550$, 567

fiber connections between cerebral cortex, cerebellum and basal ganglia 602

field, see force-field, visual field

- forces, inertial 236

- potentials, vestibular nuclei 459

fighter pilots 379

figure skaters and nystagmus $376,377,379$

filter, high-pass 536

-, low-pass 536, 562

- mechanism 172

filtering process, otolith organs 536

finger-nose test 271, 608

finish-horizontal mode of rotation test 342

- -vertical mode of rotation test 342

fish, behavior and vestibular organs $558 \mathrm{ff}$

-, compensation of labyrinthine lesions 466,472

- , dorsal light reactions 178,180

-, eye movements 560

-, frequency of canal stimulation 508

-, inverted position 555

-, ocular counterrolling 526

-, otolithic cells 523

-, otolith organs $165,517,519,527$

-, positional tests 284

-, semicircular canal responses 502, 508, $509,510,514,552$

—, vestibular nerve 607

一, vestibular organs 496,558

fixation, visual 222

- , central regulation of 211

- nystagmus 196, 198, 199, 208, 209, 210, 587

flexion paraplegia 585

flexor tonus 268

flight, aerospace - 398, 400, 401, 402

-, orbital $237,254,298$

-, parabolic 103, 235, 237, 252, 254, 298, $304,416,555,556$

-, spatial disorientation in 281

- personnel 104

flocculo-nodular connections 126

- lobe 126, 590

- -, inhibitory function on vestibular organs 426

flocculus $115,116,126$

floor standing tests 353

— walking test 353

force environment, manipulation of 235

- , effective, in a near-weightless vehicle 236

- field on the body, change of 87

- - on the head, change of 87 force field dependence 110

- - magnitude 97, 101

- plates electrobasometer 359

forces, agravitoinertial 236, 237

-, centrifugal 165

-, gravitational 236

-, gravitoinertial $236,237,247,261$

-, inertial immanent 236

forebrain, relation to vestibulo-reticulo-cerebellar system 599

- lesions 215, 216, 218, 222, 228, 475

formatio reticularis, see reticular formation

four-pole swing 234

fovea 587,599

foveal fixation 587

- smooth pursuit eye movements 587

- vision, anomaly of 208

foveate animals, nystagmus in 594

Frenzel's glasses and nystagmus 198, 199, $200,201,202,204,221,483$

frequency of stimulation of fish canals 508

-, natural, of canal system 33

-, -, of cupula-endolymph system 31

,-- , of the sacculus 70

- response of the utricle 71

friction, internal, of the gelatinous substance 70

Friedreich's atrophy 598

frog, compensation of vestibular lesions $466,467,473,475,480$

-, with extirpated canals 543

-, primary afferent neurons and linear acceleration 284

frontal aphasia 614

- eye field 586, 592, 611

- lesions, Müller effect after 94

- lobe syndrome 614

frontoparietal lesions, Müller effect after 94

function generator $599,602,603,613$

galvanic methods, ataxia 359

- nystagmus 220

- stimulation 220, 270, 272

- tests, clinical value of 435

gamma-motoneurons 479

- -spindle loops 479

ganglia, basal, see basal ganglia

gastric motility during motion sickness 400

- ulcer and vertigo 438

gastritis and vertigo 438

gastrointestinal effects and motion sickness 400

gaze, conjugate 215

- apraxia 217

- centers, subcortical 216

- nystagmus $196,198,199,214,216,219$, 587,605 
gaze paralysis 215

- - , horizontal 216

- - vertical 217

- paresis 218, 596

- positions, eccentric 589

-, hysterical pseudopalsy of 215

gelatinous substance, friction of 70

generator, function - $599,602,603,613$

geometric displacement 134

Gerlier's disease and vertigo 438, 441

Gibson texture gradients 172

glass model and motion sickness 408

glaucoma, labyrinthine 561

g level, increasing 244

- loading, increased 259

glucose, content during motion sickness 401 goal-directed movements 583

goniometers 357

gradient for retinal texture density 168

granular cells in cerebellar cortex 603,605

gravireceptor inputs, convergence of 287

- stimulation, canal responses to 295

gravireceptors, generally distributed 282

-, nonvestibular 282

- of otolith organs 282

-, somatesthetic 282,283

-, vestibular 282

- and habituation 381

gravitational acceleration 287, 291, 542

- - effect on responses to rotation 291

- - and lateral canals 292

- - sensation of 417

- forces 236

- - and ocular counterrolling 239

- stimulus and otolith activity 241

- vertical 261, 283

gravitoinertial force environments, unnatural 257

- forces $236,237,247,261$

- horizontal 247,248

- vertical 245,252

- upright 247, 255

gravity, absence of 252,254

-, constant stimulus of $259 \mathrm{f}$

-, cupula deflection by 294

-, lunar standard of $240,254,255$

-, measurement of 499

-, orientation to $16,293,305,309$

-, otolith response to 527,533

-, position relative to 18,68

-, specific, of cupula 285

,-- , of endolymph 16,303

-, -, of otoliths 16

—, tilted relative to 96

-, zero-, see weightlessness

- dependent otolith signals 563 gravity-orientation information, otolith system 105

Grunddrehung 469

guidance system, inertial 494, 495, 564

guinea pig, compensation of vestibular lesions $469,470,473,474,476,478,479,480$

gyroscope 498

gyrus, postcentral 8

habituation $362,369,382$

-, attention - 135,136

-, caloric 372,373

-, psychological 366

-, situational 366

-, vestibular $130,134 \mathrm{ff}, 361 \mathrm{ff}$

-, vestibular sensation - 425,426

- from caloric to rotatory stimulation 373

-, canal responses after 132

-, central factors of 381

- to constant rotation 342

- to Coriolis stimulation 377,382

- of Coriolis vestibular responses 380

-, nystagmus - $131,134,361,370,374$

-, oculomotor responses after 133

- to sea-sickness 410

- of turning sensation 134,379

-, room illumination during 379

- of vestibular responses and visual stimuli $369 \mathrm{ff}$

hair cells, semicircular canals 515

- - in the utricle 69

Hallpike's nystagmus 439

hallucinations $\mathbf{4 3 2}$

- of rotation 429,433

halteres of insects 500

hand movements, goal-directed 612

- - visually guided, ataxia of 218

haunted swing illusion $119,160,179$

head, force field on 87

-, illusory rotation of 557

-, orientation to gravity and otolith system 16,537

-, rotation of 121

-, stimulus vector relative to - 16

-, vestibulospinal reactions in 269

- axes 10, 537

- -fixed conditions during habituation 371

- - orientation to the vertical 537

- free conditions during habituation 371

- inclination $172,176,177$

- movements $121,123,124,197,537,538,539$

- - caloric stimulation 269

- -, disorientation by 556

- - and motion sickness 558

- - and nystagmus reduction 377

- - during rotation 381

- planes 10 
head position, regulation of 211

- - other than vertical 204, 537

- return 122

- -shaking test 200, 201, 204

- tilt $159,172,182$

- -, lateral 122

- - canal responses during 132

- trauma 203, 204

- tremor 208

- -turning vertigo 196

- up judgements 89

- - position, ellipse of uncertainty 89

headache, occipital 195, 206

- and vertigo 439

hearing impairment, vertigo with 441

- loss 195, 196

heart rate and motion sickness 395

hemianopsia 215,218

- , homonymous 217,218

hemilabyrinthectomy $452,453,454$

hemineglect 215

hemispherectomy in animals 476

hemispheric lesions, subcortical 218, 222

- - unilateral 217

hen, nystagmus $\quad 373,378$

hereditary deafness 436

heredity of nystagmus 211

heterocompensation 166,169

-, vestibular 165

higher center commands 251

history, clinical, of vertigo 194, 197

Höhenschwindel 195

holding function, cerebellar 604

- - of vestibular system $583,603,606$

- tremor 211, 227, 605, 606, 609

homeostasis, postural, to the rotating environment 342

homing 156

horizontal, apparent $162,241,558$

-, gravitoinertial 247,248

-, visual 86

-, perception of 91

- acceleration at lunar standards of gravity 255

- accelerators 106

- canals, vestibular neurons of 454

- gaze paralysis 216

- linear acceleration, sustained 79,107

- - oscillation 83,315

- nystagmus $203,207,303,483,590$

horizontality, directional cues for 169

human centrifuge $83,95,235,239,259,392$, 416

hydrops, labyrinthine $438,439,561$

hyoscine 364

hypergravic forces 240

hypermetria 604 hyperphoria 207

hypersalivation during motion sickness 399

hypersensitivity to motion sickness 407 , 408

hyperventilation and motion sickness 397 , 400

hypnosis, animal 362

- and nystagmus suppression 365

hypocapnoea and motion sickness 397

hypometria of saccades $596,598,604$

hypotension, orthostatic 398

hypothalamic lesions 613

- stimulation 613

hypothalamus 612

hysteresis in the cupula 419

illusion, audiogyral 432

— of body movements 563

-, Coriolis $553 \mathrm{ff}$

-, elevator 262

- of falling forward 527

-, ferris wheel $112,113,545,548,550,567$

-, haunted swing 119

一, inversion- $254,262,555,556$

- of a magnitude 557

-, oculogravic $72,75,95,100,104,125$, $165,234,245,252,257,259,262,416,542$, $547,551,556,558,562,563$

-, oculogyral $22,299,339,380,416,429$, 432

-, optogyral 22

-, somatogravic 104

illusory acceleration $543,548,557,561$

- direction of the vertical 556

- linear sensation 563

- rotation of the head 557

- sensations of movement $\mathbf{5 4 0}$

image velocity and visual acuity 128,129

imbalance of vestibulo-oculomotor innervation 453

immersion in liquids 87

- in "polycell" cellulose paste 87

- in water $87,89,90,91,92,93,96,112$, $234,235,247,248,259,544,545$

impulse, angular $20,121,122$

-, angular velocity 20

- stimuli 21

inability to stand 195

— to walk 195

inattention to visual stimuli 612

inclination, body - 181

-, head - 172, 176, 177

-, perceived 98

—, postrotatory 276

-, subjective 98

—, swaying 276

-, uphill 97

42 Hb. Sensory Physiology, Vol. VI/2 
incongruity of equivalent signals 178

-, optic-vestibular 178

indication time 72

indicator of position 520

individual differences in reactions to discordant stimuli 126

induced movement 172,177

- nystagmus $202,212,275,322$

- sway 251

- vestibular responses 220

induction, directional $160,178,182$

- effect 181

inertial field forces 236

- forces, immanent 236

- guidance system 494, 495, 564

- navigation, basic principles of 498

- - , three-dimensional 499

- - system 496, 516

- system, basic components of 500

- - three-dimensional case of 499

- vector, change in 562

infectous diseases and vertigo 438

inferior olive and spontaneous eye movements 213

influenza, spasms in - 215

information, angular velocity 112

- , change-in-position - 18, 90, 112

-, tactile 164

-, vestibular, cognitive awareness of 135

- content 57

- flow diagram of voluntary actions 602, 613

- theory and subjective angular velocity 56

inhibition of caloric nystagmus 222

-, cerebellar 453

-, commissural 459

-, contralateral, of type I vestibular neurons 459

-, Schiff-Sherrington - 481

- of visual motion perception 197

innervation, parasympathetic 400

-, vestibulo-oculomotor 453

input of acceleration, sinosuidal 523

- - - , step - 523

-, labyrinthine 87

-, sensory, see sensory inputs

-, somatosensory $86,87,89$

-, visual 86

insensitivity of the position sense 88

insufficiency, cerebro-vascular 195,336

-, vertebro-basilar 195, 196, 207, 228

integrating accelerometer $503,520,530$

intensity of nystagmus 201

intention tremor 609

interaction of angular and linear acceleration $281,284,291,312$ interaction, canal-otolith 121,256

-, intravestibular 104

-, neuron-glial cells 566

-, optic-vestibular 177,185

-, visual-vestibular 23,104

- of time-varying linear accelerations and angular accelerations 312

interference function 158

interfering variable 158,177

internal compensation 159,174

- friction of the gelatinous substance 70

- pallidum 608

- spatial reference system 241

internalisation of attention 261

interstitial nucleus 217

intervening variable 158,160

intestinal worms and vertigo 438

intoxication effects $130,205,210,219,223$, $229,438,441$

intracerebellar nuclei $\quad 583$

intracranial diseases 275

intravestibular conflict, visual vertical during 107

- interactions 104

introversion-extroversion scales 110

inversion illusion $254,262,555,556$

- of optokinetic nystagmus 208,219

- phenomenon 92

invertebrates, compensatory mechanisms in 465

inverted position 82,555

involuntary eye movements 197,210

- reflex counter-movements 197

ischemia of the brainstem 204

ischemic disorders and vertigo 440

jerk nystagmus $202,203,207,210,215,228$

jerks, coarse fixation 212

- , square-wave 212

joint receptors 282

joints, sensory inputs from 95

-, intravertebral, information from 437

judgement of angular displacement 44

-, head-up 89

— of postural positions 90

- of verticality 84

judgements, mean, accuracy of 84

jumbling 439

ketones, content during motion sickness 401

key symptoms for topical diagnosis 227

kinesthesia, TPK-receptor system 237

kinesthesis receptors 262

kinesthetic cues 163, 527

kinetic type I vestibular neurons 457

kinocilia, utricle 17,518

kinocilium hair 517 
Kippdeviationen 212

Körperdrehreflexe 272

Körperneigungsreflexe 272

labyrinth, loss of 582

- bleeding and vertigo 438

- hydrops and vertigo 438,440

- inflammation and vertigo 438

- malfunction 164

- tonus 464

- trauma 438, 439

labyrinthectomy $\quad 309$

- and eye movements 451

- and motion sickness 607

-, unilateral 235

,-- , compensation of 464,483

,- , effect on vestibular neurons

- and vertigo 437

labyrinthine artery occlusion 336

- -defective (LD) individuals 87, 90, 94, $95,114,239,240,242,247,248,251,259$, $260,390,418,501,528,546,547,548$

- - - and ataxia tests $324,326,327$, $329,330,331,333,335,336,344,345,346$, 347

- destruction 268

- - , acute $451 \mathrm{ff}$

- -, chronic $451 \mathrm{ff}$

- - vestibular neurons after $451 \mathrm{ff}$

- disorder and vertigo 438

- dysfunction 87

- fistula 206, 437

- function, loss of - 164, 196, 197, 321, 324

- - pathology of 430

- -, unilateral 87, 164

$-\ldots$, man without $93,106,111,113,114$, 310

- glaucoma 561

- inputs 87

- lesions 195, 196, 203, 206, 452, $463 \mathrm{ff}$

- -, bilateral $472 \mathrm{f}$

- -, unilateral $465 \mathrm{f}, 483$

- -, compensation of - in man $482 \mathrm{ff}$

- organs, tonic action of 452

- pathophysiology 463

- righting reflexes 277

- signals 85

- tilting reflexes 584,585

labyrinthitis 276

- and vertigo $439,440,441$

labyrinths, blind spot of 417

-, electrical stimulation of 220

-, maintenance of equilibrium by 7

lactate, content during motion sickness 401

lag in the perception of tilt 108,110

- in the perception of the visual vertical 108 lag-effects 82

- -, oculogravic $75,107,109,125$

lagena, fish - 559

- , function in equilibrium $\quad 559$

Lage-Nystagmus 437

Lagerungsnystagmus 437

lamina quadrigemina syndrome 484

latency, somatogyral 27,28

一, "threshold" - 30

- of vestibular response 37

latent nystagmus $198,207,211,219$

lateral geniculate neurons, vestibular influence on 130

lateral-line stream receptor 607

lateropulsion 271

laterotorsion, caloric stimulation 269

-, Menière's disease 269

law, Mulder's 30

-, Stevens' power 39, 41

$\mathrm{LD}$, see labyrinthine defective

L-dopa, oculogyric spasms 215

lead effect 111

learning, habituation 382

leghorns, nystagmus 373,378

lesions of area 8611

-, arteriosclerotic 205

- in the basal ganglia 608

- of the brain stem 196, 202, 216, 226

-, bulbar 484

- of the cerebellar nodulus 205

- of the cerebellar nuclei $199,217,587$, 605

-, cerebello-cortical 589,605

- of cerebellum 226, 228

-, cerebral 162

- of cervical roots 206

-, collicular 217

-, cortical 216,217

- of the corticofugal fibers 587

- of the diencephalon 214

- of the flocculo-nodular lobe $\mathbf{5 9 0}$

- on the floor of the forth ventricle 221

- of the forebrain $215,216,218,222,228$

-, frontal 94

-, frontoparietal 94

-, hypothalamic 613

-, labyrinthine $195,196,203,206,452$, $463 \mathrm{ff}, 482 \mathrm{f}$

- of lobules VI and VII 598

- of the MLF 214, 228

- of the medulla oblongata 202

- of the optic tract 218

- of the orbital cortex 613

— of otoliths 206

- in the pallidum 608

- of paravermis 598

- of pontine tegmentum 203,217 
lesions in the posterior commissure

- of the posterior fossa 205

217

- of the roof nuclei 478

- of the sixth nerve 215

- of the spinal cord 478,480

-, subcortical 217

-, subcortical hemispheric 218, 222

-, supramesencephalic 585

-, tegmental 484

- in the thalamus 608

- of third nerve nuclei 215

-, traumatic, of the statoacoustic nerve 195

-, unilateral hemispheric 217

- , vascular 214

-, - , in cerebral hemispheres 484

-, -, of the inner ear 195

-, - , of the thalamus 484

- of the vermis 598

-, vestibular 463

- of the vestibular nerve 196

- of vestibular nuclei 195, 203, 205, 215, 221

- of the vestibular system 198

Leuchtbrille, see Frenzels glasses

light-headedness, orthostatic 336

limbic system 126,612

limb joints, afferents from 584

- proprioception 91

— reflexes, tilting 194

limbs, sensory inputs from 95

一, vestibular innervation 268

-, vestibulospinal reactions in 269,270 , 272

line of regard, uphill inclination of 97

linear acceleration 12

- - clinical value of 435

- - constant, stimulation by 550

- -, direction of 81

- -, effect on semicircular canals 546

— - greater than $1 \mathrm{~g} 299$

- - interaction with angular acceleration 281, 284, 291

- - magnitude of 111

- - modification of the response to angular acceleration by $281 \mathrm{ff}$

- - , modification of thermal responses by 303

- - and motion sickness 390

- - and nystagmus 299, 300, 301

- - and otolith function $67 \mathrm{ff}, 415$

- _, sustained horizontal 79, 107

- - tests 226

- - vector, rotation of $309,546,548$

- accelerometer $496,498,520,530$

- displacement estimates 106

- motion and motion sickness 390

- oscillation 308

linear sensation, illusory 563

- sensors 500, 516

- velocity, determination of $538 \mathrm{ff}$

- - , measurement of 546

- , perception of $18,68,72,77,82,87$, 106

- - sensation 106, 112

liquids, immersion in 87

lobe, flocculo-nodular $\quad 126,426,590$

-, parietal 8

-, temporal 8

lobuli V to VII, and saccades 598,599

locate-and-see 130

long rotation technique 223

loop, cupula-endolymph - 19

-, gamma-spindle - 479

loss of a labyrinth 582

- of labyrinthine function $164,196,197$, $321,324,326,344$

- of vestibular function 332,430

Louis-Bar syndrome $\quad 583,598$

lunar standard of gravity $240,254,255$

- walk 254, 261

Mach-Breuer-Brown theory 283

macula, saccular 282,516

-, utricular $80,268,282,518,543$

- epithelium 517

maculae, directional polarization of cells $\mathbf{5 2 0}$

-, otolithic 416

-, utricular and saccular, relative to the head 17

macular afferents, cyclical alteration in excitability 290

- messages 163

- receptors 252, 290, 312

magnitude of angular acceleration $\quad 16$

- of linear acceleration 111

- of the resultant 83

- of static force field 96,101

- estimates of subjective angular velocity $39 \mathrm{ff}$

malaise 115

mammals, static function of otolith organs .. 165

man, see also observer, patients

-, blind, eye position in 587

一, deaf 90,95

-, compensation of labyrinthine lesions $482 \mathrm{ff}$

-, measurement of otolith function in $233 \mathrm{ff}$

- , measurement of vestibular ataxia $321 \mathrm{ff}$

-, measurement of vestibulo-spinal responses $267 \mathrm{ff}$

-, nystagmus in $193 \mathrm{ff}$

-, vestibular-defective $234,252,253$ 
man, vestibular habituation in $374 \mathrm{ff}$

- with little or no vestibular function 95

- without labyrinthine function 93, 106, $111,113,114,310,418$

manipulation of force environment 235

Mann test 353

mapping function 158

marche en étoile 272

masking of visual information 594

mastoiditis 324,326

mathematical treatment of otolithic organs 521

- - of the Steinhausen model 504

measurement of acceleration 499, 514

- of gravity 499

- of otolith function $233 \mathrm{ff}$

- of postural vertical 82,84

- of velocity $502,514,546$

- of vestibular ataxia $321 \mathrm{ff}$

- of vestibulo-spinal responses $267 \mathrm{ff}$

- of visual vertical 82

measures, direct, of subjective angular velocity 43

mechanical model of otoliths and semicircular canals 529

mechanics of otolith system $68 \mathrm{ff}$

mechanoreceptors 603,605

medial longitudinal fasciculus $214,228,268$, 586,588

- - - lesion of 214,228

- - syndrome 214

- rectus motoneurons 458

medulla oblongata, lesions of 202

- - otoneurology 227

membrane, otolith, displacement of 17

memory of change-in-position 90

- of changes in orientation 86

- of direction 104

- of dynamic sensory data 111

- dependence 110

-, long-term 614

Menière's desease (syndrome) $117,195 \mathrm{f}$, $196,229,235,269,277,324,333,334,336$, $439,440,463,483$

meningitis 91,438

-, basal, and vestibular sensation 432

-, tuberculous, and vertigo 443

- and vestibular ataxia 324, 326, 327, 330, 331

meningoencephalitis, laterotorsion 269

-, luetic, and vertigo 443

mental tasks and nystagmus $362,363,374$

mesencephalic nuclei and nystagmus 590

- tegmentum, gaze center 216, 228

mesencephalon 203

metamorphosia 162

methods, velocity-matching 43,44 migraine attacks and vertigo 441

miner's nystagmus $208,210,219$

mislocation, visual 197

MLF, see medial longitudinal fasciculus

model, adaptation- 64

- of canal adaptation 509

- of a canal with "endolymphatic" and "perilymphatic" systems 289

-, mechanical, of otoliths and semicircular canals $\quad 529$

—, mathematical, of canal response 296

-, physical, of the otolith $528 \mathrm{ff}$

-, roller pump- 288

-, Steinhausen- 503, 504, 506, 512

- torsion pendulum $19,24,30,33,41,56$

modification of the Steinhausen model 506

modulation, cyclic 111

- by the position senses 92

- of semicircular canal activity 126

momentum, angular 120,121

monkey, angular acceleration detection 509,510

-, compensation of vestibular lesions 471, 472,474

-, otolith responses 532

-, otolith structure 516,518

monocular fixation, nystagmus upon 207

- optokinetik nystagmus 219

- optokinetic stimulation 219

Moro reflex 123

mossy afferents, peripheral, to the cerebellar cortex 605

motion, see also movement

-, angular 391

-, apparent $\quad 68,593$

- linear 390

-, orbital 391

_, orbiting 391

-, passive, reception of 34

- constancy 172

- experience 179

- - perceived 114

- perception 77

- - visual $197,592,593$

- sickness $74,119,120,126,130,234,239$, $257,258,262,333,339,345,347,389 \mathrm{ff}$, $414,415,425,427$

- - and archicerebellum $607 \mathrm{ff}$

- - and head movements 558

- - and mental tasks 365

- - , sensory aspects of $405 \mathrm{ff}$

- - , suppression by drugs 401, 402

- - theories 568

- of the cupula 513

- of the environment, apparent 197

- in yaw 295

motivation centers 612 
motoneurons, abducens- 458

一, gamma 479

-, medial rectus- 458

motor cortex 600

- - input from 602

- - lesions of 217

- -, tactile adjustment $609 \mathrm{ff}$

- -, sensory afferents 610

- - vestibular afferents 8,610

- fields of the Rolandic fissure 610

- learning 604

- map of cerebral cortex 609

- system, general $581 \mathrm{ff}$

- - method for analysis 582

movement, see also motion

-, goal-directed 583

-, induced 172,177

-, natural, stimuli approximating 46

-, passive 90, 135

—, "pre-programmed" skilled 126

-, relativ, between observer and target, vi. sual acuity during 126

-, saccadic-type 603

-, vestibularly induced 194

-, voluntary $589,600,601,602,608,609$

-, whole-body 104

-, illusory sensa tions of $\mathbf{5 4 0}$

-, tactile control of 610

- of visual surroundings 119

Mulder's constant 30

- law 30,415

Müller effect $\quad 86,94,96,241,244$

multi-planar angular acceleration 392

multiple sclerosis $198,199,207,208,210$, $212,214,219,220,226,228,229,606$

muscle afferents, groupe-Ia 585

- spindles 588

- - and vestibular stimulation 277

- vasodilatation and motion sickness 398

muscles, antigravity- 268

-, extraocular 215

-, ocular 215,588

musculature, skeletal, tonic innervation 163 mutism, akinetic 613

myasthenia gravis 215

myoclonus, ocular 212

myopy and vertigo 438

myorhythmia, palatal, and spontaneous eye movements 213

Myxine, vestibular organs 496

narcosis and compensation of vestibular lesions 481

- and vestibular sensation 425

natural frequency $31,33,34,70$

- movements 46 natural redundancy 167,168

nausea $116,119,125,131,133,390,392,557$

navigation, inertial, basic principles of 498

-, inertial three-dimensional 499

- system, inertial 496,516

near-weightlessness $237,251,261$

neck, vestibulospinal reactions in 269

- afferents 584

- contribution to eye stabilization 206

- ligaments, deep, information from 437

- proprioception 225, 479

- reflexes after labyrinthine lesions 469, 471

- -, symmetrical 585

- - tonic 271, 437

- torsion 204

neoplasm, paraneoplastic consequence of 213

nerve, eighth, and motion sickness 390,405

-, - , neurotomy of 451

-, - , tumors of $439,440,442$

-, -, and vertigo $439,440,441,442$

-, extrocular 215

-, sixth, lesion of 215

-, statoacoustic 195

-, third, lesions of nuclei 215

-, vestibular $195,196,203,275,285,459$, 464

nerves, sympathetic 400

nervous system, autonomic 399

neural integrator between vestibular and oculomotor nuclei 589

- mechanisms of eye position control 588

- organization of the strategy of action $612 \mathrm{ff}$

neurasthenics, vestibular responses 361

neuritis of the eighth nerve and vertigo 441

- , viral, of the vestibular nerve 195,203

neuroblastoma, thoracic 213

neuroleptic drug, intoxication by 215,481

neuroma, acoustic $196,222,228,229,324$, 333,335

neuron-glial cell interactions 566

neuronitis, vestibular $195,336,442$

neurons, afferent, primary 284

-, canal- 509, 510, 552

-, first- and second order, of ampullar receptors 287

-, lateral geniculate, vestibular influence on 130

-, oculomotor 598

- of otolith organs, responses from 518, 519

- of the putamen 608

-, tonic 586

-, vestibular, activity during recovery 454

-, - , after labyrinthine destruction $451 \mathrm{ff}$ 
neurons, vestibular, responses to acceleration stimuli 285,290

-, 一, second order 454

-, 一, type I $454,456,457,458,459$

-, -, type II $453,454,457$

newborns, vestibular sensation of 426

nociceptive flexion reflex $\mathbf{5 8 5}$

nodulus 115

nomenclature of acceleratory stimuli 10

- for head axes and planes 10

nonfoveate animals, nystagmus in 594

non-system-bound responses 257

normal system-bound responses 256

normalization effect 162,173

nosology of vertigo 439

nuclei, cerebellar $586,587,605$

— for the eye muscles 439

-, fastigial 479

-, intracerebellar 583

-, mesencephalic 590

-, oculomotor $216,455,458,589$

-, pontine 217, 605

-, vestibular $116,195,203,205,215,221$, $261,268,285,287,290,453,459,464,479$, 587,589

nucleic acids 482

nucleus, dorsomedial 612

-, interstitial, and gaze 217

-, precommissural, and gaze 217

-, prestitial, and gaze 217

nystagmic dysrhythmia 363

- reaction, Menière's disease 269

- - in opposite directions 371

- reflexes 454

nystagmogenic zones of cortex 475

nystagmography $199,200,202,220,221$, 222

nystagmus $36,59,60,62,112,114,115,122$, $127,129,257$

-, see also eye movements

-, acquired 198, 199, 208, 210, 219

-, alcohol- 307,365

-, arousal- 261, 363

-, Bechterew's compensatory 456, 457, 474, 477, 483, 484

-, caloric $115,116,202,204,221,303,304$, $305,306,307,322,472,587$

-, 一, habituation of 372,376

,-- , inhibition of 222

-, cervical 436

-, compensatory 310

-, congenital $198,202,207,208,209,210$, $211,219,228,426$

-, convergence retractory 217

-, Coriolis- 339

-, direction-changing $302,310,561$

-, direction-reversing 113 nystagmus, dissociated 214

-, downward 128

-, epileptic 215

-, fixation- $196,198,199,208,209,210$

-, galvanic 220

-, gaze- $196,198,199,214,216,219,228$, 587,605

-, head-shaking 204

-, horizontal $203,207,301,483,590,593$

-, induced $202,212,275$

- of the jerky type $202,203,207,210,215$, 228

-, latent $\quad 198,207,211,219$

-, long-lasting central 202

-, miner's 208, 210, 219

-, neck-torsion- 204

-, ocular spontaneous 482

-, optokinetic $125,174,207,215,216,484$, $587,590,593$

-, - monocular 219

-, -, inversion of 208,219

-, otolith 68

-, paretic 216

-, pendular $198,207,208,209,210,211$, 219,606

-, - fixation 587, 605

-, positional 195, 196, 201, 204, 290, 300, $301,307,336,365,590$

-, -, pathology of 561

,,-- of the central type 205

-, -, cervical proprioceptive 206

-, - paroxysmal 205, 437, 439, 441

-, - peripheral 205

-, -, due to tumor 205

-, - , and vertigo $437,439,441$

-, positioning 196, 202, 205

-, -, pathogenesis of 206

-, postrotatory $115,225,269,285,292$, $294,302,453$

,-- , duration after labyrinthectomy 455

-, primary 60,118

-, recovery- $203,204,221,484$

-, retractory 228

-, reversing 548

-, rotating 202,228

-, 一, of the pendular type 203,207

-, rotational 472,483

-, rotation-induced 322

-, -, effect of anesthesia on 361

-, rotatory 214,483

-, secondary $60,63,118,508$

-, seesaw 214, 215

-, semicircular canal- 116,302

-, spontaneous $113,195,197,198,199$, $200,204,210,218,227,228,454,456,483$

-, - alternating 226

-, - pathological 198, 201, 202 
nystagmus, spontaneous peripheral 202

-, - physiological 199,201

,-- , in animals 211

-, - , direction of 202

-, - - following head trauma 204

-, sustained 300,301

-, - - unidirectional 288

-, swaying 276

-, upward- 128

一, vertical $113,127,590$

- , vestibular $116,118,194,198,212,216$, $218,452,586,590,592$

-, - , experimental 197

-, -, peripheral 272

-, -, spontaneous 197, 199, 201

-, - , induced by caloric, galvanic and rotatory stimulation 220

,-- , and visual acuity $127,128,129$

-, - , visual control of 131

-, voluntary 214

-, accommodation of 134

- in achromatopsia 211

-, adaptation of $134,508,510$

-, adaptation time constant of 296

-, adjustment of 134

- during alertness 362,363

- and angular acceleration 62

- during backward pitch 128

- and barbiturate intoxication 590

- of the contralateral side 203

- by Coriolis cross-coupled stimuli 124, 527

- and Coriolis illusion $\mathbf{5 5 4}$

- and cortical stimulation 477

-, cyclic modulation 113

- in dancers $369,376,377$

- after deceleration 378,548

-, dependence on orientation of the head 292

-, directional difference in 129

-, directional predominance of $\mathbf{4 5 2}$

-, effect of orientation to gravity on 293 , 305,309

-, effect of time-varying linear accelerations 308

-, effect of vision on 116

-, fast phase of 469

- during forward pitch 128

- in foveate and nonfoveate animals 594

-, genesis of, role of otoliths and canals in310

- , heredity of 211

- of indefinite duration 548

- and labyrinthine lesions 452, 453, 454, $455,456,458,472,483,546$

- and lesions in different brain regions 484

- and lesions of the corticofugal fibers

587 nystagmus and lesions of flocculo-nodular lobe 590

-, and linear acceleration greater than $1 \mathrm{~g}$ 300

- and linear acceleration stimuli 550

- in man $193 \mathrm{ff}$

- and Menière's disease 195

- and mental tasks $362,363,374$

- and mesencephalic nuclei 590

- upon monocular fixation 207

- during off-vertical rotation 111

-, plane of 302

-, produced by a rotating vector and labyrinthine function 310

-, rapid phases of $217,586,588,590,592$

-, response to angular acceleration 291, 302

-, response to linear acceleration 546,548

-, reversal during deceleration 48

- in sea-sickness 405,407

- and sensed rotation 549

-, Steinhausen model of 506

-, during stimulation of $y$-axes and z-axes 52

-, stimulus of gravity during 261

- and subjective angular velocity 66

- , time constant of decay of $294,295,296$, 297

- cupulogram 421, 430

- curve, methods of 429

- diagnosis 202

- habituation $131,134,370,374$

- intensity 201

- modification, induced by visual-vestibular interaction 132

- reduction 377

- rhythm 586

- suppression $35,116,118,126,127,128$, $130,302,305,362,365,370,376$

- - and sensation 425

- velocity, decay of $62,111,123$

objective angle of tilt 242

- indicants of canal function 295

- vertical 242

observers, see also man, patients

-, blindfolded deaf, orientation ability of 90

— immersed in "polycell" cellulose paste 87

- immersed in water, see water immersion

-, labyrinthine-defective (LD), see labyrinthine-defective individuals

- with spinal lesions 87

- with unilateral labyrinthine function 87

occipital headache 195, 206 
ocular counterrolling $68,94,103,226,234$, $235,239,252,259,517,525,526,554,563$

- countertorsion $159,174,178$

- disorders and vertigo 438

- displacement, utricular and saccular influences on 102

- muscle dystrophy 215

- myoclonus 212

- nystagmus, spontaneous 482

oculogravic effect $\quad 96$

- illusion 72, 75, 95, 100,104, 125, 165, $234,245,252,257,259,262,416,542,547$, $551,556,558,562,563$

- - delay 542

- lag effect $75,107,109,125$

- response 96

- tilt 82

- crises 215

oculogyral effect 22,117

- illusion 22, 299, 339, 380, 416, 429, 432

- reactions, thresholds estimated from 35

oculogyric spasms 215

oculomotor apraxia 218

- control 130

- effectors, tonic control of 454

- neurons, atrophy of 598

- nuclei, premotor apparatus 216

- - vestibular influences on $455,458,589$

- nucleus 214

- response to accelerations 291

- - after habituation 133

- - during horizontal oscillation 315

- syndrom, abnormal 207

- system and motion sickness 401

- -vestibular system, species differences 583

off-vertical rotation, responses to 111,113 , $234,235,262$

oliguria 401

olive, inferior 213

ophthalmoplegia, external 275

- , internuclear $214,228,229$

ophthalmoscope 207

opsoclonus 212,213

optic, see also visual

- chiasma, section of 216

- postural reflexes after labyrinthine lesions 471

- tectum 217, 588, 604,612

- - , stimulation of, and saccades 592

- tract, lesion of 218

- -vestibular ambiguity $\quad 179$

- - conflict situations 181

- - equivalence 177

- - incongruity 178

- - interaction 177,185

- - orientation to the vertical $155 \mathrm{ff}, 184$ optic-vestibular weight ratio $180,181,182$, 185

optical compensation 177

- determinants of the optic-vestibular weight ratio 181

- direction cues 163, 166, 178

- feed-back 169

optogyral illusion 22

optokinetic aftereffect 118,119

- afternystagmus 125

- disturbance 587

- nystagmus $125,174,207,208,215,216$, $218,219,484,587$

- reactions 174,178

- regulation of eye position 197,199

- roll component 127

- stimulation $115,116,117,118,119,127$

- -, monocular 219

- - and motion sickness 401

optostatic eye countertorsion 178

- responses 178

orbital cortex 126,613

— flight 237, 254, 298

- motion 391

orbiting without rotation 390

- spacecraft 103, 391

orientation 155

-, body- 156

- to gravity $293,305,309$

- of the head to gravity 16,292

- , memory of changes in 86

-, perceptual 156

-, optic-vestibular, to the vertical $155 \mathrm{ff}$

- relative to the body 85

- relative to the earth 112

-, spatial 156,194

- to the vertical under water 249

- ability, egocentric 91

- - of blindfolded deaf observers 90

orthogonality of space perception 162

orthostatic hypotension 398

- light-headedness 336

- vertigo 439, 441

oscillation, angular $127,312,313$

- of the apparent vertical 180

-, damped 509

-, horizontal linear $77,83,105,106,315$

- linear 308

-, phase reversals of 432

-, rotatory, clinical methods 432

—, side-to-side 87

-, sinusoidal, thresholds estimated from 30

-, vertical linear 77

oscillatory after-reactions, periodically 434

- shear vectors 88

- stimulation 76,77

oscillopsia 208,210 
osteochondrosis 206

otitis media 440

otoconia 517

otolith, physical model of $528 \mathrm{ff}$

- activity and gravitational stimulus 241

- apparatus and vertical constancy 163, 166

- canal interactions 256

- -detected earth reference 115

- function and attenuated vestibular and nonvestibular cues 86

- -, experimental methods of 234

- - and gravity 235

- - and linear acceleration $67 \mathrm{ff}$

- - in man $233 \mathrm{ff}$

- - threshold stimuli for 75

- membrane, displacement of 17

- nystagmus 68

- organ function and alcohol 258

- - - and drugs 258

- organs 178

- -, anatomy of 517

- -, blind spot of- $80,242,436$

- - filtering process of 536

- - gravireceptors 282

- - gravitoinertial forces in near-weightlessness 237

- - in lunar walk 254

- -, mathematical treatment of 521,530

- - , perception of space $237,261,282$

- - primary neurons of 518

- -, responses from 517

- -, stimulation by linear acceleration 415

- - transfer function of 531

- - left and right, relative function of 235

— sickness 262

- signals, acceleration-dependent 563

- - gravity-dependent 563

- - processing of $533 \mathrm{ff}$

- stimulation 86

- - and motion sickness 391, 408

- - and ocular counterrolling 525,526

- stimuli, dynamic 68

- -, static 68,261

- system, acceleratory stimuli 16

- - angular velocity information 105

- - change-in-orientation information 105

- - gravity-orientation information 105

— - mechanics of $68 \mathrm{ff}$

- -, mode of stimulation 235

- - oculogravic illusion 245

- - orientation of the head to gravity 16

- - and postural equilibrium 261

— thresholds 86,87 otolithic cells, polarization of 518,520

- - responses from $518,519,524,525$, $527,529,532,533,547$

- - , types of $515,519,520,524,525,527$, $529,531,532,533,547$

- input, stabilization of visual space by 242

- maculae 416

- signal processing 540

otoliths 18,121

-, utricular 112

- and determination of rotation 547

-, displacement of $69,70,71$

-, dynamics of 69,71

一, fish- 559

-, lesions of 206

- as linear sensors 516

-, plane sensitivity of 96

-, role in habituation 373

- and rotation of the body

- in sea-sickness 405,407

- and semicircular canals, complementary working of 543

-, specific gravity of 16

otoneurology $193 \mathrm{ff}$

otosclerosis $275,430,431$

over-compensation 241

overshoot 56,58

overstimulation of vestibular organs 568

oxygen, content during motion sickness 401

paleo-cerebellar connections 126

paleocerebellum, motion sickness and 126

pallidum, lesions in 608

palsy, bulbar progressive 228

-, extraocular muscle- 215

-, extraocular nerve- 215

-, post-traumatic pseudobulbar 336

parabolic (aircraft) flights 103, 235, 237, $252,254,298,304,416,555,556$

paradox, Aubert-Fleischl 52

paradoxioal phase of sleep 261

parallel fibers of the cerebellum 604

- -swing rotation 549

- swings, experiments with 106, 163, 416, $418,435,436,541,559,562$

paralysis, abducens- 8

- of cranial nerves and vertigo 439

- , gaze- 215,216

-, vestibular 482

parametric gain adjustment via climbing fiber action 604

paraneoplastic cerebellar encephalopathy 213

paraoxon 482

parasympathetic innervation and motion

sickness 400

parasympatholythic action of drugs $\quad 402,410$ 
paravermis, lesions of 598

paresis, gaze- 218,596

parietal lobe 8

Parinaud's syndrome 217,228

parkinsonism 215, 608

paroxysmal positional nystagmus 205

- - vertigo 196

passive movement 90,135

pastpointing 239, 271

patellar reflex 276

path of body movement, perception during off-vertical rotation 111

- of passive movement 90

patients, see also man, observers

-, abnormally fatigable 361

-, schizophrenic 365

-, catatonic 361

pattern building, vestibular sensation 424

pattern-copy 426,427

pathology of vestibular sensation $413 \mathrm{ff}$

peak cupula deflection 38

pendular angular acceleration 223

- eye deviations during angular acceleration 211,212

- nystagmus 198, 203, 207, 208, 209, 210, $211,219,587$

pendulum, overdamped 503

-, spring- 81

-, torsion- 415, 420, 502

Pensacola Slow Rotation Room 338, 339, $340,343,344$

pentetrazole 482

pentobarbital 364

perceived inclination 98

- motion experiences 114

- position 83

perception, see also determination, sensation

- of acceleration 554

- of angular acceleration, thresholds of$23 \mathrm{ff}, 432$

- of angular velocity $18,56,125$

- of body rotation 118

- of displacement 106

- of horizontal 91,97

- of linear velocity $18,72,77,82,87,106$

- of motion 77

- -, visual 592,593

- of orientation relative to the earth

112

- of space $156,162,164,237,238$

- on starting the head movement 121

- of tilt $18,68,77,81,96,102,108,110$, 125

- of upright 104,238

- of velocity 21

— of verticality $68,75,82,90,91,97,103$, $108,109,163,164,177,185$ perception and the vestibular system $566 \mathrm{ff}$ perceptions during changing horizontal linear accelerations 105

perceptual coordinate systems 164

- orientation 156

- reconstruction 166

- space orthogonality 162

- space transformations 156,164

perilymph, blood in 206

perilymphatic fluids 562

- systems, model of a canal with 289

peripheral mechanisms of habituation 373

periodically oscillatory after-reactions 434

perphenazine 481

persistent rotation experience $\quad 112$

personal space, perception of 238,261

personality, unity of 614

- dimensions 110

perspiration during motion sickness 399

perturbed system-bound responses 257

perverted direction of caloric nystagmus 221

pharmacology of compensations of vestibular lesions $481 \mathrm{ff}$

phase angle, stimulus response- 38,73

- - between the response magnitude and stimulus velocity 33

- reversals of the oscillations 432

phasic secondary after-sensations 433

phenobarbital 481

phosphorus, content during motion sickness 401

photographic methods, ataxia 357

photophobia pains $\mathbf{4 4 0}$

physical model of the otolith $528 \mathrm{ff}$

picrotoxin 481

pigeon, compensation of vestibular lesions $463,465,472,477,479$

-, vestibular habituation $371,372,373$

pilots, see also astronauts

-, determination of the vertical 538

-, vestibular habituation 376,379

pitch, forward, sensation of 123

- axes 302

- errors 89

- -nystagmus 127,128

platforms, elevated 359

-, tilting 357

plugging experiments, semicircular canals 543

pointing experiments $239,268,270,271$

polyneuritis 215

pontine angle tumor 213

- nuclei 605,614

- - gaze paralysis 217

- reticular formation $214,586,590$

- tegmentum, gaze center 216,228

- - lesions of 203,217 
pontine tuberculoma 590

position, angular 18

-, erect, thresholds 82

-, head-up- 89

-, inverted 82,555

-, perceived 83

-, experience of 179

- relativ to gravity 18,68

-, seated, thresholds of 81

-, static 18,92

-, determination of $497 \mathrm{f}$

- indicator 520

- receptors 163

- sense, absence of 88

- - insensitivity of 88

- -, modulation by 92

- - sensitivity of 89

- sensing units 71

- signaling, consistent 112

- - during off-vertical rotation 111

positional change indicator $\mathbf{5 2 0}$

- nystagmus 195, 196, 201, 204, 205, 206, $290,300,301,307,336,365,437,439,441$, 561,590

- responses in canal afferents 284

- test 201, 284

- vertigo 196, 206

positioning of the line relative to the body, egocentric 95

- nystagmus 196, 202, 205, 206

positions, postural, and reduced somatosensory cues 88,90

$\ldots, \ldots$, and reduced vestibular and nonvestibular cues 90

-, side-down, thresholds of 82

-, standing 94

-, starting 88

positivity, pre-motion 600

post-acceleration primary reaction 60

postcaloric sensation 435

postcentral gyrus 8

posthabituation tests 133

posterior commissure, lesions in 217

- fossa, lesions of 205

postrotation effects 341,343

postrotational canal responses 92,119

- reactions, secondary 427

- responses, time constant of decay of 297

- sensation of turning 115

postrotatory inclination 276

- nystagmus $115,225,269,285,292,294$, 302,455

- sensation, adaptation of 429

postural cue system 179

- direction cues $163 \mathrm{ff}$

- disequilibrium 239, 257

- equilibrium $250,261,333,346,352$ postural equilibrium responses 156

- - test battery 234, 250

- homeostasis to the rotating environment 342

- positions 88,90

- reflexes 113, 163, 471, 472

- sensations 164,174

— stability, rigid 251

- standard 176

- sway 251

- tilt 76

- tremor 609

- upright 249

- vertical $82,83,84,90,109,125,249$

- vertigo 336

posture, bibliography of 352

potassium, content during motion sickness 401

potentials, cerebral, preceding voluntary movements 600,601

-, readiness- 600

power law $39,41,56$

practice, effect on visual acuity 130

precommissural nucleus 217

pregnancy and vertigo 438

pre-motion positivity 600

premotor apparatus for eye rotation 203

- neuronal apparatus of oculomotor nuclei 216

pre-programmed skilled movement 126

pressure on the body surface, distribution of 163

- receptors 237, 262, 282

prestitial nucleus 217

pretectal area $\mathbf{5 8 8}$

- region, gaze center 216,228

primary after-reaction 61

- post-acceleration reaction 60

prism spectacles 160

prisms, right-left reversing 131,604

-, displacement of visual field by 134

-, distorted visual input by- 134

procain and vertigo 437

projection area, vestibular 8

prolonged rotation 344

proprioception, limb- 91,584

一, neck- 225,479

-, nonvestibular 330

- and vestibular system 582

proprioceptive cervical nystagmus 206

- feedback from the eye muscles 599

- inputs 338

- mechanisms, nonvestibular 344

protein content of endolymph 562

- - during motion sickness 401

proximal stimulus 158

pseudo-Coriolis effect 119,401 
pseudopalsy, hysterical 215

psychic states, vestibular responses 361

psychogenic disorder 336

- - and vertigo 438

psychophysical variable 158,159

pulsations of blood-vessels 251

pupillary light reaction 217

Purkinje axons 599

- cells 587, 603, 605, 608

- effect 119

pursuit eye movements $199,219,587,588$

putamen, neurons of 608

pyknolepsia, petit mal attacks of 196

rabbit, compensation of vestibular lesions 468,473

- , nystagmus $371,372,373$

rail ataxia test 327

- method 357

- test battery 250

ramp generator, basal ganglia 608

- movements, voluntary 589,608

Ramsay-Hunt syndrome and vertigo 441

rapid eye movements 362

ray, canal responses to angular velocity 502

一, otolith responses 519

- labyrinth, time constant 285

reaction, post-acceleration primary 60

- , secondary, as sign of adaptation 62

-, subjective, to angular acceleration 21

-, - , to semicircular canal stimulation 18

- time 28

readiness potential 600

reafference principle 156

reafferent component 172

- sensory signals 605

- volleys, rapid movements by 606

reafferents 7

receptors, ampullar $282,283,291,312$

-, canal- 251

-, joint 282

-, macular $252,282,290,312$

-, nonotolith, loss of cues from 248

-, position- 163

-, pressure 282

—, somatosensory 251

-, stimulated by linear and angular acceler. ation 282

-, tension- 163

-, touch 237, 282

-, TPK- $234,235,237,244,245,249,251$, 261

reconstruction 156

-, perceptual 166

- principle 166,169

recovery, neuronal vestibular activity during 454 recovery nystagmus $203,204,221,484$

recruitment of cupula sensory cells 514

redundancy $167,178,179$

-, natural 167,168

-, expectations $167,168,172$

reference axes, otolith organs 522

reflex, Achilles tendon- 276

-, antigravity stretch 585

-, cervico-ocular 223

-, Moro- 123

-, nociceptive flexion 585

-, patellar 276

- actions relativ to the earth 18

- arc, cortico-cortical 600

- -, vestibulo-ocular 291, 586, 590

- counter movements, involuntary 197

- response gains 251

- vestibular disturbances 257, 262

reflexes, deep, to vestibular stimuli 276

-, labyrinthine 584,585

-, labyrinthine righting 277

-, nystagmic 454

-, postural 113, 163

-, security- 179

-, tendon- 276

一, tilting 194, 584

-, tonic neck- $271,437,584$

-, vestibular, in the trunk 271

-, vestibulo-autonomic 268

-, vestibulo-ocular 268

-, vestibulo-spinal $267,268,277$

- after labyrinthine lesions 469, 471, 472

regulation, central, of fixation 211

- of head position 211

rejection syndrome, motion sickness 568 , 570

REM sleep 261,364

renal resorption during motion sickness 401

representation, cortical vestibular 7

repugnance, theory of 572

residual ataxia 345

respiration and motion sickness 400

response curves, supraliminal 27

- decline of sensation 426

- duration, working equations 38

- latency, threshold methods and working equations 37

- magnitude, phase angle between- and stimulus velocity 33

- reduction, habituation 382

responses, non-system-bound 257

-, normal system-bound 256

-, perturbed-system-bound 257

- to stimulation of semicircular canals $52 \mathrm{ff}$

resting discharge 286

- tremor 608 
restoration, vestibular 451

restoring force, elastic, of cupula 29

resultant, magnitude of 83

— force, tilted to 96

retardation, viscous 29

reticular formation $257,261,426,459,469$,

$475,479,584,586,589$

- - pontine $214,586,590$

- nuclei of brainstem 601

- -, step generator 599

- - of the tegmentum 217

- system, interplay with vestibular system 34

reticulospinal tract 268

retinal image velocity 117

- message 172

- stimulus field 181

- texture density, gradient for 168

- velocity, vision during vestibular nystagmus 128

retractory nystagmus 228

retrospective displacement estimation 51

return to upright, speed of 85

reverie and nystagmus 363,365

reversal in apparent motion 68

- phenomenon 477

reversing prisms 604

rhythmic after-sensations 419

- stimulations 425,426

Richtungsinduktion 160

right-hand rule of rotation 12

righting reactions, compensatory 277

- reflexes, labyrinthine 277

rigidity 608,609

rigid postural stability 251

Risatarun 482

RNA 482

rodents, optokinetik nystagmus 219

Rolandic area 609, 610

Rolandic fissure 610

role of expectation $\quad 117$

roll axes 302

- errors 89

- nystagmus 127

roller pump model 288

Romberg's test $250,273,276,322$

- - classical 336,353

- - unipodic 353

roof nuclei, lesions of $\mathbf{4 7 8}$

room, rotating $338,339,340,343,344,392$

- illumination during habituation 379

roots, dorsal 479,584

rotatable chambers 117

rotating chair, clinical use of 223

- environment 132

- - postural homeostasis to 342

- linear acceleration vector $286,546,548$ rotating nystagmus $202,203,228$

- platform 131, 133

- room $338,339,340,343,344,392$

- surrounds 118

- water tank 545

rotation 269

-, constant, adaptation to 339

-, constant velocity- 111,288

-, continuous $\mathbf{5 5 0}$

-, -, of the linear acceleration vector 309

-, earth-horizontal 234

-, eccentric 299

-, off-vertical 111, 113, 234, 235, 262

-, parallel-swing 549

-, prolonged 344

-, reversed, sensation of 56

-, steady 180

-, aftersensation of 418,419

- of the body and otolith response 543

- of the body in space 547

-, determination of 547

- about an earth-horizontal axis 115, 116

- about an earth-vertical axis 116

- of the environment 547

-, hallucinations of 429,433

- of the head 121

- of immersed subjects 544,562

- of a linear acceleration vector 290,546 , 548

-, responses to-, effect of gravitational acceleration 291

-, responses to-, effect of sustained acceleration 298

-, right-hand rule of 12

-, sensation of $16,115,418,419,423,427$, $547,549,550$

- of the striped field 170

- about a tilted axis 113

- aftereffects 92

- -dependent cells 549,567

- detection 34

- experience, persistent 112

- -induced ataxia 344

- - nystagmus 322

- tests, clinical value of sensation in $\mathbf{4 2 7}$

rotatory acceleration 415

- autokinesis 242

- excitability tests 220

- eye movements 202

- nystagmus 214, 483

- oscillations, clinical methods 432

- stimulation 220, 272

- vertigo 437

route perception 156

Ruttin compensation 472 
saccade $197,588,605,611$

-, see also eye movement

-, coarse 596

-, fast-phase- 128

-, correction- 594, 596

-, horizontal spontaneous 597

-, hypometria of $596,598,604$

-, refractory period for 592,593

saccadic burst activity $\mathbf{5 8 6}$

- - duration 603

- eye movements, dysmetria of 596,598 , 603

- - - functional crossing of the mechanisms for 216

- - - and rapid phases of nystagmus 590

- function, discontinuous, of cerebellar cortex 602

- pulse generator 594

- reaction time $\mathbf{5 9 6}$

- -type movements 603

saccular influence on ocular displacement 102

- macula 282,516

- - relative to the head 17

- as tilt indicator $102 \mathrm{ff}$

- plane 103

- sac 517

- shear $82,102,103$

- signals, temporal patterning of 112

- units, responses from 533

saccule $16,17,71,98,102$

-, equilibrial function 235

一, natural frequency of 16

-, sensitivity of 87

-, static function 164,165

sacculus, see saccule

salivation during motion sickness 399

satiation effect 162,173

sclerosis, disseminated, and vertigo 442

scopolamine and motion sickness 402

sea sickness $369,405 \mathrm{ff}, 430$

seated position, thresholds 81

Schiff-Sherrington inhibition 481

- phenomenon 479

schizophrenic patients, nystagmus 365

secondary nystagmus 63

- reactions as sign of adaptation 62

section of corpus callosum 216

- of optic chiasma 216

security reflexes 179

seeing during eye movement 130

- during vestibular stimulation 130

seesaw eye movement 203

- nystagmus 214,215

seizures, adversive 215

self-rotation, inducing vestibular ataxia semicircular canal, see also canal

- - activity, modulation of 126

- - function 20, 106

- - information, conflicting 108

- - nystagmus 116,302

- - response, postrotational 119

- - stimulation, subjective reactions to

18

- - - visual acuity during 126

- - - and visual information 116, 177

- _timuli and habituation 132

- - - unnatural 135

- canals, acceleratory stimuli to 14,546 , 551

- — and angular acceleration 503, 509

- - as angular sensors 501, 502, 509

- -, appropriate stimuli 415

- - disturbance of 202,206

- - , frequency response 585

- - gravitoinertial forces in near-weight. lessness 237

- - location of angular acceleration vector by 116

- - matched sets 54

- - mechanical model of 529

- - normal range of operation 505

- - and otoliths, complementary working of 543

- - plugging experiments 543

- - responses of - in fish 502, 508, 509, 510,514

- - , response to linear acceleration 549

- - and sea-sickness 405, 407

- - stimulus wave forms 20

- - three coplanar pairs of 14

- -, turntable stimulation 18

- -, velocity transducer 504

- - horizontal, response to stimulation of $52 \mathrm{ff}$

- - vertical, response to stimulation of $52 \mathrm{ff}$

sensation, see also determination, perception

- of angular velocity 424

- of centrifugal acceleration 417

- of change of position 418

- for diving 123

- for forward pitch 123

- of gravitational acceleration 417

- of linear movements 418

-, response decline of 426

- of rotation $16,56,115,418,419,423$, 427,550

- of tumbling 119

- of turning, see turning sensation

- during turning acceleration and deceleration 21 
sensation, climbing 123,125

-, illusory, of movement $\mathbf{5 4 0}$

-, linear velocity. $72,106,112$

-, postcaloric 435

-, postural 164, 174

-, secondary 63

-, tilting 87

-, vertiginous 133,380

-, vestibular 7

-, -, pathology of $413 \mathrm{ff}$

- cupulograms $28,406,408,409,421,422$, 423,428

- cupulometry 429

- curve, methods of 429

- threshold 430

sensibility, deep 88

sensitivity, directional 290

sensorimotor cortex 609

sensors, angular 500,501

-, linear 500, 516

一, static position- 18

sensory anchoring 244

- arrangement 134

- aspects of motion sickness $405 \mathrm{ff}$

- association areas 599

- data, dynamic, memory of 111

- inputs from joints 95

- - from the limbs 95

- - from TPK system 244

- interactions on vestibular habituation 130

- signals, reafferent 605

shear, saccular 82,102

一, utricular $82,85,87,89,98,99,100,102$

- component 68,102

- -, beyond $\mathrm{lg} \quad 102$

- - saturation effect 100

- , tangent function 100,101

- movement 517

— vectors, oscillatory 88

sheer 530

shock 570

Shuller tuning 499

side-down positions, thresholds 82

- -to-side oscillation 87

sign of adaptation, secondary reactions as 62

signal detection theory 36

- redundancy 179

signals, synergistic, from ampullar and macular receptors 312

sinusoidal cupulometry 66

- oscillation, thresholds estimated from 30

- stimulus 21

SISI tests 234

skaters, after-sensation skaters, nystagmus in $376,377,379$

skeletal musculature, tonic innervation 163

skin, anesthesia and postural judgement 88

-, touch and pressure receptors 282

- pallor and motion sickness 393,399

skull fractures 483

sleep, REM- 261

-, paradoxial phase of 261

-, spontaneous nystagmus in- 201, 211

-, stimulus of gravity during 261

- and vestibular sensation 425

sleepiness during motion sickness 400

somatesthetic gravireceptors 282,283

somatogravic illusion 104

somatogyral effect $22,26,117$

- latency 27, 28

- reactions, thresholds estimated from 35

- thresholds 26

somato-sensory afferents, influence on compensation of vestibular lesions $479 \mathrm{ff}$

- cues 93, 94, 113

- -, attenuated 91

- - , reduced, and postural positions 88, 90

- discrimination of tilt 110

- fields of the Rolandic fissure 610

- inputs $86,87,89$

- mechanisms 261

- receptors 251

- signals 85,112

- system $83,89,94,96,121,234$

- - , and otoliths 18

somesthetic cues, eliminated 545

- disorders and vertigo 438

- factors 164

- sensors and determination of rotation 547

space, extrapersonal $237,238,261$

-, personal 237, 238, 261

-, phenomenal 159, 179

-, visual, constancy of 197

-, exploration of 251

-, nonvisually perceived direction of 249

-, visually perceived direction in 238,241

- coordinates and cerebral lesions 162

- perception, constancy of 156

- -, orthogonality of 162

- - otolith organs 237,261

- platforms 117

- sickness $402,554 \mathrm{ff}$

- situation, adaptation to 557

- transformation, perceptual 156,164

spacecraft, horizontal 244

-, weightless 237

spasms, oculogyric 215

spatial disorientation in flight 281

- movement patterns 604 
spatial orientation 156,194

- perception, conflicts in $\mathbf{5 5 5}$

- reference system, internal and external 241

specific gravity of endolymph 16,303

- gravity of otoliths 16

speaking, strategy of 614

speech, neural organization of 614

- discrimination 234

speed of return to upright 85

- of turning 21, 22

spinal cord, effect of vestibular stimulation on 268

- - influence on compensation of vestibular lesions $479 \mathrm{ff}$

- - lesions 478, 480

- - - observers with 87

- regulations $\mathbf{5 8 5}$

- transection 585

spinocerebellar connections $\quad 481,603$

spinoreticular afferents 481

spontaneous nystagmus $113,195,197,198$, $199,200,201,202,203,204,210,211$, $218,226,228$

spot, blind $80,242,417,436$

spring pendulum 81

- system, damped 19

Sprungbereitschaft 407

square-wave jerks 212

squint, concomitant 207, 208

squirrel monkey, detection of angular acceleration 509,510

- - motion sickness 427

- - otolith responses 532

- - otolith structure 516,518

SR, sharp Romberg, see Romberg

stabilimeter 356

stability, rigid 251

stabilization, high-frequency 251

-, low-frequency 251

-, vestibular, of eye- and body postures $194,583,585,587,588$

stable-platform system 499,564

standard reference direction 174,175

stand eyes closed 250,323

- eyes open 250,323

- on a leg eyes closed 250,323

standing on the head 555

- on the moon 556

- on rails 357

- positions 94

starting positions 88

star walking test 353

static counterrolling 525,526

- force field, influence on tilt perception 96

- otolith stimuli 68

- position 91,92 static position sensor 18

- responses of otolithic cells $519,520,525$, 532,533

- tilt relative to gravity 81

statisch-optische Verhältniszahl 180

statoacoustic nerve, traumatic lesions of 195

statoconical mass, motion of 290

- plaque, torsion of 290,312

statokinesimeter 356

statolith elimination, fish 472,473

Steinhausen Model 495, $503 \mathrm{ff}, 504,506,512$

step function, cerebellar 604

- - generator 599, 603

- movements, dysmetria of 605

stepping in situ 273

- test 226, 272, 273, 275, 354

stereocilia 17,517

Stevens' power law 39,41

stimulation, caloric $220,269,270,272,274$

- by constant linear acceleration $\mathbf{5 5 0}$

- Coriolis $377,383,382,527,563$

-, electrical, of labyrinths 220

-, galvanic $220,270,272$

-, hypothalamic 613

-, optokinetic $115,116,117,118,119,127$

-, - monocular 219

-, oscillatory 76,77

-, rhythmic 425,426

-, rotatory 220,272

-, semicircular canal- 18

-, sinusoidal 429

-, thermal 220

stimuli, acceleratory 10,13

-, approximating natural movements 46

-, discordant, reactions to 126

-, "impulse" 21

-, otolith dynamic 68

-, - static 68

-, unpredictable 589

-, vestibular Coriolis cross-coupling 123, 124,125

stimulus, acceleration-step 20

-, distal 157, 158

-, centrifuge- 79

-, Coriolis torque 133

-, gravitational 241

-, proximal 157, 158

-, sinusoidal 21

- patterns, typical 20

- response phase angle 38,73

- variables, otolith function 234

- vector relative to the head 16

- velocity, phase angle between- and response magnitude 33

- of gravity, constant $259 \mathrm{f}$

- - loss of 262

strabismus 207,215 
strain gauges 359

strapped-on system 499, 564

strategy of action, neural organization 599, $612 \mathrm{ff}, 613$

- of speaking 614

streptomycin and ataxia $324,333,334$

- and vertigo 438

- intoxication 197, 223, 309, 431, 482

stress effects and motion sickness 401, 571

stretch reflex 585

striate area, destruction of 218

- cortex 611

striola 530

strio-nigro-pallidum 602

strychnine 481,482

subclavian steal syndrome 196

subcortical gaze centers 216, 217

- lesions and gaze paralysis 217, 218, 222

- white matter 228

subgravity levels 235

subjective angle estimation 424

- angular velocity $39 \mathrm{ff}, 43,44,47,54,421$, 422

- cupulogram 421, 422

- displacement measures 48

- inclination 98

- indicants of canal function 295

- linear velocity 68

- reactions to semicircular canal stimulation 18

- reactions to simple angular acceleration 21

- responses in relation to otolith dynamics 71

- rotation aftereffects 92

- tilt 80

- velocity estimates 379

- vertical 100

- vestibular reactions 378

subjects, see man, patient, observer

submarine navigation 494

superior colliculus $217,596,612$

suppression, mechanism of 296

- of ampullar responses 302

- of canal-dependent responses 123

- of nystagmus $35,116,118,126,127,128$, $130,302,305,362,365,370,376,425$

- of sensations of turning 295,296

- of visual brightness perception 197

-, central, of the signal from lateral canals 294

supragravity range 240

- states 234

supraliminal response curves 27

supramesencephalic lesions 585

suspension by straps 93

sustained accelerations, caloric tests sustained accelerations, effect on responses to rotation 298

- - , horizontal linear 79,107

- nystagmus $288,300,301$

sway, induced 251

-, postural 251

- motion, and vestibular-defective subjects 252

swaying inclination 275

- nystagmus 276

sweating during motion sickness 399

swimming, without orientation sensitivity 91

swing, four-pole 234

—, parallel 106, 163, 416, 435, 436, 541, 549, 559,562

-, torsion- $223,425,427,429$

-, two-pole 391

- illusion, haunted $119,160,179$

sympathetic nerves and motion sickness 400

sympathomimetic action of drugs 402

synaptic endings, degeneration of 459

syndrome, Cogan's 440

-, Gerlier's 438, 441

-, Louis-Bar- 583, 598

-, Menière's, see Menière's disease

-, MLF- 214

-, oculomotor abnormal 207

-, Parinaud's 217, 228

-, Ramsay-Hunt 441

-, rejection- ( $=$ motion sickness) $\quad 568,570$

-, subclavian steal- 196

- Wallenberg's 202, 203, 227, 228, 442, 484

syphilis 214,438

syphilitic interstitial keratitis 440

syringobulbia $202,215,226,227,228,443$, 483

tabes dorsalis 276,438

tactics of action $599,602,613$

tactile control of movements 610

- direction cues 163

- information 164

tandem walking test 353

tangential acceleration $\quad 282,283,286$

- component 83

- displacements, otoliths 70

target displacement 106

- oscillation 127

targets, observer-fixed 127

tectum opticum $217,588,592,604,612$

tegmental lesions 484

tegmentum, reticular nuclei of 217

-, mesencephalic 216, 228

-, pontine 216,228 
temporal coordination of movements

- lobe 8

- - epilepsy 196

- movement patterns 604

- patterning of utricular and saccular signals 112

tendon reflexes and vestibular stimuli

tension receptors 163

test pilots 232, 425

texture gradients, Gibson 172

- -, retinal 168

thalamic afferents to area $8 \quad 612$

thalamus, vascular lesions of 484

- , ventro-lateral 602,608

theory, bicomponent- 164

-, signal detection 36

-, torsion pendulum 37,40

thermal responses, modification by linear accelerations 303

- stimulation 220

- - of ampullar receptors 306

thoracic neuroblastoma 213

Thorner ophthalmoscope 207

threshold, concept of 35

- acceleration, working equations 38

- determination by centripetal acceleration 79

- - by extrapolation of supraliminal response curves 27

- - with oscillatory stimulation 77

- - by sustained horizontal linear acceleration 79

- - by tilt relative to gravity 82

- latency 30

- shifts over time 34

- stimuli for otolith function $\mathbf{7 5}$

- stimulus, cupula deflection 284

thresholds, somatogyral 26

- for electrical excitation of vestibular neurons 453

- of electrical vestibular nerve stimulation 459

- for frequency response of vestibular neurons 454

-, otolith- 86

- for the perception of acceleration 432

- of perception of angular acceleration $23 \mathrm{ff}, 223$

- of positions 81,82

- of somatesthetic gravireceptors for linear and angular acceleration 283

tilt, apparent 119

-, body- $83,162,182$

-, dynamic 106

-, head- 122, 132, 159, 172, 182

-, initial 85

-, oculogravic 82 tilt, postural 76

- relative to the force field 96,97

- relative to gravity $81,82,96,98$

-, static 106

一, subjective 80

-, adaptation to 72,90

-, angle of 242

-, discrimination of 106,110

-, discrimination of linear acceleration from 105

- and high-magnitude linear accelerations 107

- and oculogravic lag effect 107

-, perception of $18,68,77,81,102,108,110$, 125

-, - influence of static force field on 96

-, underestimation of 106

- chair 249, 435

- -, hard 88

- - padded 87,88

- - t tilting on 83,169

- devices 93

- information, saccule 98

- -, utricular shear 98

- positions, static 91

- rooms 110

tilted buildings 110

tilting platforms 357

- reflexes, labyrinthine $\quad 584,585$

- - of limbs 194

- -, vestibular 584

- sensations 87,392

- on the tilt chair 83,169

time constant $285,294,295,296,297,315$

- -varying linear accelerations 308,312

tinnitus 195,196

tipping reactions 269,277

- table 277

tone, vestibular 452

tonic actions of labyrinthine organs 452

- activity of vestibular neurons 452

- control of oculomotor effectors 454

- eye fits 215

- innervation of skeletal musculature 163

- neck reflexes 271, 437

- neurons 586

- - type I, vestibular 457

tonus, arm- 227,270

-, body- 163

-, extensor- 268

-, flexor- 268

- asymmetries in the vestibular system 484

Tonus-Labyrinth 464

topical diagnosis, key symptoms for 227

torsion dystonia 608

- pendulum 415, 420,502 
torsion pendulum model (theory) $30,31,33,37,40,41,56$

— swing 223, 425, 427, 429

touch, receptor system $237,262,282$

TPK receptor system 234, 235, 237, 244, $245,249,251,261,262$

- sensory input, astronauts 244

tract, vestibulo-spinal $\mathbf{4 7 9}$

transducers, angular velocity 20

transfer from caloric to rotational stimulation 381

- function of otolith organs 531

transformation of spatial into temporal patterns 604

transient acceleration $\quad 540$

trauma, acoustic 336

traumatic lesions of labyrinths 203, 206

- - of statoacoustic nerve 195

treading test 272

treadmill 359

treatment of motion sickness 402,410

tremor $227,605,606,608,609$

Tretversuch 272

trunk, vestibular reflexes 271

-, vestibulospinal reactions in 269,271

tuberculoma, pontine 590

tuberculous meningitis and vertigo 443

Tullio effect 426

tumbling sensations 119

tumor and positional nystagmus 203, 205, $207,213,214$

- and vertigo $438,439,440,441,442$

turning, speed of 21,22

- sensation 115, 299

- -, accommodation of 134

- -, adaptation of 134,296

- -, adjustment of 134

- , and angular acceleration 291

- - definition of the stimulus 40

- -, effect of vision on 116

- - habituation of 134,379

- -, suppression of 295,296

turntable, secondary 390

typhus and vertigo 438

$\mathrm{U}$ deg, postural vertical 84,85

一, visual vertical 86

Umkehrphänomen 477

uncertainty, arc of, see arc of uncertainty, $\mathrm{U}$ deg

-, ellipse of, see ellipse of uncertainty

under-compensation 241

underestimation of angular displacement 49

— of tilt 106

underwater two-axis gimbals system 89

unilateral labyrinthectomized patients unilaterial labyrinthine defective (UL-Ds) $324,333,335,336$

units, canal-dependent 112

-, change in position. 72

-, position sensing 71

unity of personality 614

uphill inclination of the line of regard 97

upright, gravitational 239

-, gravitoinertial $239,247,255$

-, postural 249

-, perception of 104, 238

-, return to 85

uremia and vertigo 438

urine during motion sickness 401

utricle 14,16

-, estimated plane of 98

-, frequency response 71

-, hair cells in 69

-, kinocilia 17

-, static function 164,165

- shear plane 85

utricular influence on ocular displacement 102

- macula $17,80,268,282,518,543$

- otoliths, angular velocity information 112

- sac 517

- shear, lateral 100

- - component $82,85,87,89,98,99$

- - , physiological limits of 102

- - hypothesis 99, 102

- signals, temporal patterning of 112

- units, responses from 533

utriculofugal deflection 15

- endolymph flow 453

utriculopetal deflection 15

- endolymph flow 453

utriculus, see utricle

variable, compensatory 173,177

-, interfering 158,177

-, intervening 158,160

-, psychophysical 158,159

vascular changes, motion sickness 393

- collapse 195

- disturbances and vertigo 438

- lesions 195, 214, 484

vasoconstriction and motion sickness 398

vasovagal syndrome, vestibular stimulation 398

vector, inertial 562

- analysis and static response of otolithic units 532

-, acceleration- $12,15,79$

-, shear- 87,88

vegetative symptoms 195 
velocity, angular $18,20,21,112,113,122$, 125,515

-, constant, adaptation for 515

-, linear $18,68,106,112,546$

-, - , perception of $72,77,82,87,106$

-, slow-phase, nystagmus 62

-, determination of $497 \mathrm{f}$

-, measurement of 502,514

- estimates, subjective 379

- information, by canal-dependent units 112

- -matching procedures 43,44

- perceptions 21, 77

- ramps 20,21, 24

- step 21

- triangle 21

ventricle, fourth, lesions in 221

Verhältniszahl, statisch-optische 180

veridicality, ideal, deviations from 161

vermis and motion sickness 607

- and saccades 598,599

vertebral artery, compression of 196

vertebrobasillary circulation and vertigo 440

- insufficiency $195,196,207,228$

vertical, apparent $86,160,162,169,170$, $174,176,178,179,180,181,182,241,242$

-, - , as a function of lateral body tilt 161

-, -, in or out of water 248,249

-, gravitational 261, 283

-, gravitoinertial 245,252

-, objective 242

-, postural $82,83,84,90,109,125,249$

-, subjective 100

-, true 84

-, vestibular 174

-, visual $72,82,85,92,93,95,97,100,101$, $107,108,109,125$

-, determination of $534 \mathrm{ff}$

-, illusory direction of 556

-, optic-vestibular orientation to $155 \mathrm{ff}$

-, sense of $540,542,562$

- canals, pathology of 432

- constancy $157,166,172$

- gaze paralysis 217

- indication, ability of 91

- linear oscillations 77

- nystagmus $113,127,590$

- writing test 270

verticality, directional cues for 169

-, estimate of 83,84

-, judgement of 84

-, perception of $68,75,82,90,91,103,108$, $109,163,164,177,185$

vertige de l'enfance $\mathbf{4 4 0}$

vertiginous sensations 133,380 vertigo $179,194,197,205,206,227,324$, $336,337,392,396,414,438$

-, acute 439

-, cervical 436

-, childhood- 440

-, chronic 439, 442

-, concentration-camp- 438

-, continuous 195

-, epileptic 196, 439, 441

-, head-turning 196

-, long-lasting 195

-, nonvestibular 438

-, orthostatic 439,441

-, paroxysmal 439,440

-, positional $196,206,437,441$

-, positioning 196, 437, 441

-, posttraumatic 442

-, postural 336

-, rotatory 437

-, spontaneous 437

一, attacks of $195 \mathrm{ff}$

- and blood pressure 196, 438

-, clinical history of 194,197

- due to disorders of the vestibular system 438

-, general criteria 196

- due to general disorders 438

- without hearing disorders 441, 442

- with hearing impairment 441

- of labyrinthine origin $\quad 196,438$

-, nosology of 439

vestibular adaptation 369,567

- afferents, projection to motor cortex 8

- apparatus, phylogenetic connections with cerebellum $\mathbf{4 7 7}$

- ataxia, measurement in man $321 \mathrm{ff}$

- compensation 177, 451

- Coriolis cross-coupling effects 119, 120, 121, 125, 131

- Coriolis cross-coupled reaction 133

- Coriolis cross-coupling stimuli 124,125

- cortical activity 8

- - projections 610

- cues and otolith function 86

- -, reduced, and postural positions 90

- -defective subject $234,252,253$

- defects, otolith function 234

- direction cues 163,164

- excitability, diminished 212

- eye movements, visual inhibition of 201

- frequency response to angular acceleration 223

- function, compensation of 460

- , effect of poisons 481 
vestibular function, loss of 332,430

- - men without 95,332

- - , systems approach to $565 \mathrm{ff}$

- gravireceptors 282

- habituation $134,361 \mathrm{ff}$

- - mechanisms of $134 \mathrm{ff}$

- - in man 374

- - , sensory interactions on 130,134

- heterocompensation 165,166

- influences on oculomotor nuclei 455

- on lateral geniculate neurons 130

- information, cognitive awareness of 135

- innervation of limbs 268

- input-output relations 254

- lesions, compensation of $463 \mathrm{ff}$

- - and laterotorsion 269

- model 541

- nerve, see also nerve, eighth

- - diseases of 275

- - functional loss of 482

- - , recordings from 285

- -, threshold of electrical stimulation 459

- - and vertigo 438

- - viral neuritis 195,203

- - destruction 203

- - fibers, spontaneous activity in 464

- - lesions 196

- neuronitis $195,336,442$

- neurons, activity during recovery 454

- - after labyrinthine destruction $451 \mathrm{ff}$

- - responses to acceleration stimuli 285 , 290

- - tonic activity 451

- - , second order 454

- - type I $454,456,457,458,459$

- - type II $453,454,457$

- nuclei 261, 285, 584, 587, 589

- -, medial $268,287,290,453,479$

- -, analogy in function with cerebellar nuclei 607

- - field potentials in 459

- - lesions of $195,203,205,215,221$

- - , negative waves in 459

- - and optokinetic stimulation 116

- - responses to acceleration stimuli 285

- - , spontaneous activity in 464

- nystagmus $116,118,127,128,129,131$, $194,197,198,199,212,216,220,272,477$, 586,590

- -oculomotor pathology 126

- - reflex system 130

- organs as an inertial system 501

- _ and motion sickness 390,408

- -, overstimulation of 568

- - , self-adapting system 426

- - , specific stimuli of 414

- - , systems concept of $493 \mathrm{ff}$ vestibular paralysis by streptomycin 482

- projection area 8

- receptors in elasmobranchs 284

- reflexes in the trunk 271

- regulation of eye position 197

- release to unidirectional angular acceleration 223

- representation, cortical 7

- response reduction 361

- responses, compensatory 295

- - induced 220

- - habituation of- and visual stimulation $369 \mathrm{ff}, 373,377$

- - modulation by intravestibular and visual-vestibular interactions 104

- restoration 451

- righting responses 156,180

- sensations $7 \mathrm{ff}$

- - direct and indirect 7

- -, attention to 67

- - pathology of $413 \mathrm{ff}$

- sensors, resolution of acceleratory stimuli 13

- -somesthetic influences 181

- stabilization of body posture 194, 583

- - of eye position $194,583,585,587,588$

- stimulation, effect on spinal cord 268

- - by multiplanar accelerations 393

- -, seeing during 130

- - and subjective responses 18

- stimuli and deep reflexes 276

- -, pattern and counterpattern 426

- structures, acceleratory stimuli to 10

- system and body control 500

- -, efferent 285

- - , holding functions 583

- -, interplay with reticular activating system 34

- - lesions of 198

- -, motor functions $581 \mathrm{ff}$

- - and perception $566 \mathrm{ff}$

- -, pathological disorders 560

- -, proprioception and- 582

- - tonus asymmetries in 484

- - , visual feedback to 604

- tilting reflexes 584

- tone 452

- tracts in the cerebellum 390

- vertical 174

- vertigo 195

vestibularly induced movements 194

vestibulo-autonomic reflexes 268

- cerebellum 604

- ocular reflex arc 291, 586, 590

- - reflexes 268

- oculomotor innervation, imbalance of453 
vestibulo-oculomotor symptoms 227

- -reticulo-cerebellar system 599

- -spinal disequilibrium 226

- - reactions in head and neck 269

_ - - in lower limbs 269,272

_ - - in upper limbs 269, 270

- - - in tipping reactions 269

- - - in trunk 269,271

- - reflexes $267,268,277$

- - responses, classifications of 269

- - - measurement of $267 \mathrm{ff}$

- - tests $226,267 \mathrm{ff}$

- - tract 268, 479

- -vegetative disorders and motion sickness 402

vibration, whole-body 126

viral encephalitis 213

viscosity of endolymph $\quad 507,562$

viscous retardation 29

visible surrounds, tilting of 109

vision, blurred 195

-, double 195

-, dynamic, directional difference in 129

-, foveal 208

-, absence of, during rotation 116

-, effect on nystagmus and turning sensations 116

- and motion sickness 401

- during vestibular nystagmus 127,128

- -detected earth reference 115

visual, see also optic

- acuity, dynamic 130

- -, effect of alcohol on- 130

- - effects of practice on 130

- - during semicircular canal stimulation $126 \mathrm{ff}$

- - and image velocity 128,129

- afterimages 106

- attention 612

- autocompensation 169

- brightness perception, suppression of 197

- control of vestibular nystagmus 131

- - of the vestibulo-ocular reflex arc 590

- direction cues 166

- feedback 587, 604

- field, displacement by prisms 134

- - -dependence 104, 109, 110, 117

- - -independence 104,109

- fixation, influence on caloric response 222

- frame, effect on the visual vertical 109

- - of reference 109

- holding function 588

- horizontal 86,97

- image, fixation during head movement 502 visiual induction 182

- information and apparent rotation about an earth-vertical axis $\quad 116$

- - masking of 594

- - and semicircular canal stimulation 116

— inhibition of nystagmus 376

- - of vestibular eye movements 201

- input 86

- - of the archicerebellum 604

- - distorted, by prisms 134

- mechanisms and somatosensory input 244

- mislocation 197

- pathway to the cerebellum 604

- perception of motion $197,592,593$

- - of verticality 177

- postural reflexes, compensation of loss of both labyrinths 472

- reference versus body reference 106

- space, stabilization by otolithic input 242

- - constancy 197

- stabilization of eye position 587

- still-fixation and nystagmus 375,378

- stimulation and habituation of vestibular responses $369 \mathrm{ff}, 373,377$

- — and vestibular Coriolis cross-coupling effects 125

- stimuli, inattention to 612

- suppression 117

- - of caloric nystagmus 116

- - of vestibular nystagmus $35,126,127$, 128,130

- surroundings, movement of 119

- system 234

-- , compensation of vestibular function 460

- vertical $72,82,85,92,93,95,97,100$, $101,108,109,125,177$

- - during intravestibular conflict 107

- -vestibular interactions 23, 104, 132

- - interplay 127

visually perceived direction in space 238 , 241

voluntary actions 613

- eye movements $211,600,601$

- movements, cortical organization 600

- nystagmus 214

- ramp movements 589,608

vomiting $125,131,133,195,569$

walk eyes open 323

- on floor eyes closed 323

-, heel-to-toe 323

- a line eyes closed 323

-, lunar 254, 261 
walk a straight line 250

walking, blindfold 272

- deviation 272

- experiments 268, 272, 353, 357

- at night 321

- on rails 357

Wallenberg's syndrome $202,203,227,228$, 442,484

waltzing test 272,354

water immersion $87,89,90,91,92,93,96$, $112,234,235,247,259,544,545,562$

- - and apparent vertical 248, 249

wave machine 390

waves, negative, in vestibular nuclei 459

weightless spacecraft 237

weightlessness $104,234,237,244,262,298$, $307,308,398,402,545,555$

-, caloric tests 304

Wernicke's aphasia 614
Wernicke's posture 585

wheel effect $112,113,545,548,550,567$

white matter, subcortical 228

whole-body angular oscillation 127

- displacement relative to the earth 106

- movement 104

- vibration 126

wobble board 357

- detection during constant speed off-vertical rotation 113

- meter 357

yaw, angular oscillation in 312,313

-, motion in 295

- -nystagmus 127

yawning during motion sickness 400

zero gravity, see weightlessness

- -g experiments 103,555 